\title{
El libro VIII de la «Confessio Amantis» portuguesa
}

\author{
ANTONIO CORTIJO OCAÑA \\ (University of California) \\ Maria Do Carmo Correia de Oliveira \\ (Universidade Católica Portuguesa)
}

H. L. S., doctor ruboris causa (Inf. XI, 50)

El libro VIII de la Confessio Amantis nos permitirá adentrarnos en el apasionante tema de la traducción, al respecto de las versiones del mismo que se conservan en las lenguas peninsulares. La Confessio Amantis de John Gower (ca. 1390) dará lugar en el siglo XV a dos versiones en la Península Ibérica, en portugués y español. La primera será traducción de Robert Payn, desde el inglés; la segunda - traducción desde el portugués, no desde el inglés--, será obra de Juan de Cuenca.

El texto castellano ha sido editado tres veces, por Birch-Hirschfeld (Hermann Knust), Elena Alvar (y Manuel Alvar) y Alan Deyermond ${ }^{1}$. El texto portugués no ha sido editado al completo hasta ahora, sino en estas páginas. El ms. portugués en que basamos nuestra edición (Palacio II-3088) es a su vez copia de otro portugués, como puede deducirse - entre otros motivos - por algunos errores de salto de línea(s) del copista o alguna lacuna del texto castellano (que no falta en el original portugués), que indican a las claras que se estaba copiando de un texto anterior.

Dejamos para otra ocasión referimos en detalle a problemas mayores en lo que se refiere a lagunas y modificaciones del original portugués en el libro al completo, la Confessio, y su comparación conjunta con el texto castellano que se nos ha conservado ${ }^{2}$. En lo que toca exclusivamente al libro VIII, indi-

1 Para los estudios de la Confessio Amantis en sus versiones peninsulares remito a los estudios de Alvar y Santano Moreno (más Russell y Pietsch). Para la historia del descubrimiento del texto portugués y una bibliografía completa al respecto de los estudios de la misma, remito a Cortijo $(1995,1997,1998,2001)$. Para una bibliografía sobre el texto portugués puesta al día ver BITAGAP (la biblografía portuguesa excelentemente realizada por A. Askins, Aida F. Dias y M. Schaffer) y Correia de Oliveira (2001a, b, 2002, 2003).

2 Señalemos, no obstante, algún que otro error de entre los más curiosos. En el libro V (cap. CXXXVII del texto castellano), el texto portugués al hablar de la estatua de Apis indica que «e antre as marauylhas que acontecerom contasse en como Alexandre, byndo de Cãdaça per hũu lugar deserto, achou hũa lapa a sso hũu monte;» la frase en castellano se pervierte, pues se cuenta «en cómmo el rrey Alyxandre, vinjendo de caça (por Cädaça...) ». En el libro VI del texto castellano, el cap. CLXXV está muy corrompido, entre otros motivos por haber una lacuna considerable (de un 
quemos que la fidelidad de la traducción castellana es impresionante, como no podía ser menos entre dos lenguas lo suficientemente cercanas para permi-

folio) por salto del copista al comenzar dos folios con la misma expression, «como fez Bacus». Tal como figura en la edición de Alvar se lee: «...dos toneles llenos de breuaje de Amor que a los coraçones [...] [f. 266b] [...] commo fizo este Bacus e pensar cómmo éste, dando bozes, con graçia alcançó graçia...». En el ms. portugués, sin embargo, dicha lacuna no existe, y queda así:

Aqui conta, segundo o poeta, dos dous tonees que tem Jupiter em sua adega, dos quaees hũu he cheo do beuer doçe e o outro damargoso.

«[A] Fortuna, de todolios casos dos homẽes per tal modo proçede da alta Proujdença dos deuses, que o cobramento de todo amor primeiro he ala ordenado ante que seia aqui posto ẽ obra. Ca Jupiter, que sobre todos he o mais alto deus, tem na sua adega dous tonees cheos de beueragem damor, que faz os coraçõoes de muytos aas uezes amergulhar e aas uezes nadar ẽ doçura ou amargura. E hũu delles he cheo dhũu doçe beuer, que chamã pymente, o qual he de tal propriedade, que, quãdo homẽ del gosta, logo em hũu ponto faz o sseu coraçom tanto alegrar, que trespassa o entendiemento de todo o seu saber. Outro amarga como o fel e faz botar o coraçom do homẽ de tal guisa, que por o ssentido do amargamento a ssua beuediçe se lhe torna em grande ỹfirmydade. Cupido he copeiro destes beueres anbos e parte $\operatorname{co}[\sim]$ quem el quer dhũu e do outro, e hũus faz ryr $\mathrm{e}$ outros faz enbruscar. Mas, porque el he çego, muytas uezes desuya do camynho dereito e em uez do boo toma o maao, a qual cousa contra toda rrazõ he aazo do desffazimento de muytos homẽes $e$ esso meesmo de sseu adiantamento. Assy que algũs se ssentem agrauados de doença que de rrazom deuyam de sseer sãaos. E outros chegã alla en tal ora que beuem do mjlhor sem o mereçendo. E per esta guisa o copeiro çego em uez de claro da o turuo. Ves per que maneyra el sabe toruar os coraçõoes dos homẽes sem ley de gouernança; fazeos beuer todos segundo sorte, mas quando el tyra do tonel doçe todo o noio da beuediçe damor he entom uençido, ẽ tanto que, aynda que el cada serãao assy beuesse, nõ sse agrauaria, ca todo se lhe tomaria em jogo. Mas quãdo tyra do tonel amargoso tal beuediçe, logo rrooe o coraçõ do homẽ e afraquenta todo seu pẽssamento, que mjlhor fora de comer pã seco ssem beuer, como aquel que por beuediçe perde entõ o sseu praziuel camynho e nõ sabe pera onde hir por as carreiras que acha scorregadias, nas quaees per uenta poderia asy caer que el quebrantaria todo seu ẽtendimento. E per este modo os homẽs som aas uezes beuodos, segundo os beueres que elles ẽ antes ia beuerom. Pero todos nõ beuem per hũa maneyra, ca algũus ham rrezom de cantar e outros de sospirar. E porem, filho, eu nõ som marauylhado dos padeçimentos que tu as em Amor, porque eu bem sento per o teu rrazoar que tu as beuydo aquela beueragem amargosa ataa que Deus te enuye graça de corregimento. Mas, filho, tu pidyras e rrogaras, assy como fez Bachus em terra stranha seendo muyto apressado com sede natural, por tal que tu possas chegar a aquella praziuel fonte onde a tua noiosa sede damor, gostando doçura, pode sseer apagada".

Nota aquy en como per aazo da oraçom o beuer aas uezes he tragido ao que ha sede, e conta por enxenplo o que aconteçeo a Bacus na terra de Lybea, byndo dhũa batalha que antes ouuera nas partes do Ouryente.

«[E]ste Bacus, filho de Jupiter, andãdo em guerra longe no Oryente per mandado de sseu padre, leuou consigo mũỹ gram poder, onde assy xe lhe açertou que ouue uyctoria de seus ẽmjgos, e tornousse com grande õrra per hũa terra seca perto do rreyno de Lybia. E aconteçeo hũa tal auentura, que nom podia achar augua nẽ outro lycor con que sua sede podesse apagar, por a qual cousa el e sua gente toda per mỹgua de beuer stauam ẽ põto de seerem destroydos. Bacus, ueendo aquesto, começou de rrogar a Jupiter, dizendo em esta guisa: «Oo alto padre, que todo uees e a quem he rrezõ de rrogar e pidyr ao tenpo da neçessydade; para mentes e ordena maneyra en como esta sede que auemos seia apagada e outorganos que possamos chegar em saluo aa terra õde nossas senhores stam aguardando nossa bjnda». Dictas estas pallauras, a sua oraçom ante os seus deuses foy ouuyda, e logo per ante seus olhos pareçeo hũu carneyro, que com as mãaos staua scauãdo a terra, e fez hi naçer hũa ffonte dhũa augua mũỹ fresca e clara, da qual el e todollos da sua oste fforom auõdados como elles quiserom. E por esta graça que lhes entom assy aueo, Bacus naquelle lugar hũu tenplo 
tirlo $^{3}$. En alguna otra ocasión (Cortijo en prensa) ya he podido establecer con un detalle que no permite el espacio de que ahora disponemos que Juan de Cuenca es traductor fidelísimo, aunque ello no implique que no esté constantemente ejerciendo su oficio de traductor en las múltiples labores de cambios de orden de elementos en un sintagma, variando el texto ligerísimamente, añadiendo pequeños matices, suprimiendo otros, introduciendo glosas, aclarando lo que considera oscuro, etc.

La pregunta que debemos hacernos es si existe alguna diferencia de peso entre las dos traducciones, en este libro VIII y último de la Confessio. La primera respuesta es que no la hay: la versión castellana es fiel, cercana al texto portugués y sin modificaciones ${ }^{4}$. Pero dos textos no son nunca fieles a tal punto (por mucho que se parezcan las lenguas de traducción) que el texto traducido no deje de aportar la singularidad del traductor. Estudiaremos aquí algunas de dichas singularidades, aunque sin afán de exhaustividad ${ }^{5}$.

Una modificación relativa tiene que ver con la estructuración de los capítulos. En una ocasión el texto castellano introduce nuevo capítulo donde el texto portugués no lo hace. Así, en el capítulo XXI del texto portugués (CCCXL del castellano), la frase «Ora conta a cronyca, tornando aa mjnha materia de que eu dantes falley, que...» («Cuenta agora la corónica...») es inicio de un capítulo nue-

mũỹ rrico mandou fazer, por tal que os que ham sede, quãdo <ouuyssẽ ou uessem> [o uessem ouuyssẽ] pera ssenpre dello rrenẽbrança. Porem, filho meu, por esto que entõ assy aconteçeo deuyas de parar mentes e rrogar ao tenpo do mester como fez este Bacus, e penssar en como ele braadando per graça ouue e cobrou graça...".

Como último ejemplo, en el libro $\mathrm{V}$ del texto portugués, la frase « $\mathrm{Ca}$ ẽ caronjca aynda se acha scripto cousa que nüca ha de sseer aqueeçida" (dentro del "fallso tetemunho», Historia de Troya) se traduce mal en castellano como «cosa que nunca fue acaesçida». Asimismo, varios avatares de la historia el Ulises, del libro IV, están ausentes del texto del de Cuenca, no así en portugués.

${ }^{3}$ También lo es la traducción portuguesa de Robert Payn, y aun más si cabe. Payn se embacó en un caso poco frecuente de traducción de un texto en lengua germánica a otro en lengua románica, y para más inri de uno en verso a uno en prosa. La fidelidad de su traducción ha sido ya objeto de los estudios de conjunto (aunque indirectamente a través de la traducción castellana, única con que se contaba) excelentes de Santano Moreno y especialmente Alvar (con sus numerosísimos comentarios desperdigados en nota a pie de página), que indican los saltos, lagunas y desvíos en la traducción (pocos para la extensión de la misma). Algún comentario vertido por algún estudioso (que silenciaremos) sobre el hecho de que Payn pudiera haber perdido la fluidez y conocimiento de su lengua materna (fruto de algún desliz aquí y allá en su traducción) es simplemente erróneo de todo punto.

${ }^{4}$ Un estudio minucioso y pormenorizado (frase a frase) de los 8 primeros capítulos de la Historia de Apolonio de las versiones portuguesa y castellana está ya realizado en Cortijo en prensa. Por mor de no repetir aquí lo allí indicado, a él remito para más información. No hablaremos, pues, aquí de dichos capítulos, y esta notas se centrarán en el resto de la Historia de Apolonio y el Epílogo con que concluye el libro VIII.

5 Dejamos aquí de lado (por no corresponder a estas notas) problemas de diverso tipo que afectan la edición del texto portugués, y que en nuestra edición quedarán explicados. Por ejemplo, el libro VIII está en un estado de cierta confusion en la encuadernación del ms. Así, se ha incluido dentro del mismo un fragmento de un fol. que pertenece al libro III; igualmente, en la secuencia de folios de que actualmente se compone el ms., parte del Epílogo final, de nuevo otro fol. completo (que sigue inmediatamente a la Historia de Apolonio) no aparece en su orden adecuado. 
vo en castellano, el CCCXLI: «De cómmo Apolonio viniendo por su fija Taysa falló que era muerta» ${ }^{6}$.

A errores varios de traducción pueden atribuirse las siguientes inexactitudes. Al comienzo del libro VIII (antes de la Historia de Apolonio), cap. 1, sospechamos que alguna corrupción del texto base, o que Juan de Cuenca no entendiera la complicación del original, le hizo modificar sustancialmente al traductor el siguiente fragmento:

O todopoderoso Deus, que de sy medes he sem começo e todallas cousas tẽ começadas aa ssua uõtade, assi como the aprouuge écheo de toda gloria e prazer aquel çeeo en que el ssee entronyzado em sua seeda, preseruando pera sseu seruj̧̧o çertos angos que nom podem errar nem desuyar do sseu mandado.

[E]l Todopoderoso Dios, que de sý mesmo es syn comyenço, et todas las cosas començó a su voluntad, e commo le plogo, es lleno de toda Gloria e plazer aquel çielo en que Él está entronizado en la su sylla, rreseruando para su serujçio çiertos ángeles que no pueden errar nj desuyar de su mandado.

En este mismo capítulo, más adelante, Juan de Cuenca entiende mal la palabra portuguesa «desassisado» (en la frase «eu nũca em amor fuy tã desassisado», $\tan$ 'sin seso', 'loco') y la traduce como «deseado», que no tiene sentido. En la misma frase, la palabra «fym» («nẽ ssej maginar a que fym eu auya dendoudeçer por nehũa freira») se ha traducido como «yntynçión», reduplicando por error la misma palabra que aparecía una línea más arriba: «Yo nunca en Amor fuy tan deseado que amys parientas oujese de amar so aquella yntynçión, pues non sé a qué yntynçión...». La preocupación por la precisión, cuando quizá la traducción literal pudiera resultar ambigua en castellano, da lugar a modificaciones como la siguiente, también del primer capítulo de la Introducción:

Ora ueio mũỹ bem, filho meu, que a tua pallaura senpre sta ẽ hũu lugar.

Agora veo, buen fijo mjo, que tu voluntad e palabras syenpre están en un ser.

En el capítulo XII del texto portugués (ahora ya en la Historia de Apolonio), la hija del rey pide a su padre «que lhe desse logar pera aprender daquele homẽ nouo a doctrina daquella sciençia que elle sabya». Juan de Cuenca tiene cierta dificultad con la expresión «homẽ nouo» y traduce erroneamente: «...que le diese lugar para aprender de aquel onbre nueva doctrina de aquella çiençia que él sabía». En el mismo capítulo, se nos narra cómo la doncella enferma de amor («esta uirgem per aazo de uagar continoado $\langle\mathrm{fez}\rangle$ cahio em hũu tal caso que amor contra sua fresca e fraca moçidade fez hũa querella en tal guisa...»). El texto castellano queda transcrito por Deyermond de la siguiente manera: «aquesta donsella por causa del vagar continuado cayó en un tal caso que amor con toda frasea fiso una querella en tal guysa...». Alvar indica en nota que «K-B, de

${ }^{6}$ El texto castellano de la Historia de Apolonio propiamente dicha se cita por la edición de Deyermond. El texto castellano de los primeros capítulos del libro VIII que preceden a la Historia de Apolonio se cita por la edición de Alvar, así como el del Epílogo. Hemos trancrito, por imperativos

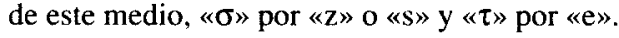


acuerdo con el original inglés, corrigen en fuerça el frasca del ms.» (nota 82). Está claro, sin embargo, que Juan de Cuenca ha leído mal el texto original, posiblemente interpretando el abreviado contra como con toda y confundiendo fresca e fraca en frasca, dejando la oración en un anacoluto.

En el capítulo correspondiente al XVI del texto portugués, la frase «Assy que em sperança que o corpo arribasse ẽ saluo em algũa terra lançarõno entõ fora ao mar sem mais tardança» (en la traducción castellana «Asý que en esperança que el cuerpo arribase en salvo en alguna manera, lançáronlo fuera de la naho en el agua») queda ampliada mediante la siguiente frase: «E luego encontynente la fortuna çesó». Nótese, de paso, que la traducción puede estar errada en dos ocasiones. La primera, porque es posible que el «manera» castellano responda a un «terra» portugués (en abreviatura en el original), mal leído. Asimismo, «fora ao» podría haber confundido a Juan de Cuenca en su traducción «fuera de la naho», por el parecido fónico.

Las rúbricas suelen encontrar una traducción literal (o muy cercana), aunque ello no es óbice para que Juan de Cuenca deje volar la pluma en alguna ocasión. Así, compárense las rúbricas al capítulo XVIII del texto portugués, harto disímiles:

[Capítulo XVII] En como Cyrimõ o phisico achou o corpo da fynada en terra açerca da çidade de Ephasym e como achou em ella o pulsso de tal guisa tenperado, que prouando em ella sua grande mesteria lhe fez cobrar o folgo que em ella era mortifficado.

Que trata de cómmo un grant físyco que se llamava Çirimo falló el arca en que yva el cuerpo finado de la rreyna en tierra junto con el agua çerca de la çibdad de Efesym. E por su buen saber le fiso cobrar el spíritu vidal que tenya traspuesto en poco tienpo.

En el capítulo XIX del texto portugués (y habiéndose producido la confusión motivada por esta palabra con anterioridad en alguno de los libros precedentes), Juan de Cuenca traduce el «asynou» ('asignó') portugués por un «enseñó», error obvio. A fines del mismo capítulo, el texto castellano deja una frase con sujeto ambiguo cuando deja de traducir «o meestre da naao», que en portugués indica a las claras quién es el sujeto. En la frase siguiente, y aunque Juan de Cuenca suele traducir con fidelidad los nombes propios, el «Leomyno» portugués da lugar a un «Leovinyus,» de nuevo error de lectura.

En la rúbrica al capítulo XXI, se indica que Apolonio se marcha de Tiro a buscar «sua filha a Tarssya». Juan de Cuenca cambia del todo el sentido al equivocarse en su traducción, pues en español Apolonio «fue buscar a su fija Taysa».

A comienzos del siguiente capítulo, el XXII, se nos dice que Teófilo llegó donde su señora y le contó que había matado a Taysa y la tenía enterrada en un lugar secreto, como se le había mandado. Sin embargo, la frase siguiente en portugués («e, por ende, por tal que a cousa nom fosse descuberta, diselhe que teuesse todo mũỹ bem em porydade») se deja de traducir al completo en castellano. 
Más abajo, en el siguiente capítulo, vuelve a dejarse de traducir una frase portuguesa en castellano. Compárense los dos textos:

Mas ella porem nõ o quys assy fazer, e chegousse pera el onde jazia no scuro e tocouho hũu pouco cõ as faldras, polla qual cousa se el tanto assanhou que lhe deu hũa palmada.

Mas ella non lo quyso asý faser, antes se llegó adonde él estava, por la qual cosa él se tanto ensañó que le dio una palmada.

Unas líneas más abajo, Juan de Cuenca hace de nuevo gala de su capacidad para modificar el texto original (quizá motivado por la dificultad):

E desy en diãte começoulhe de contar o que longamente tynha guardado en ssy dentro que o nom ousaua desobrir a nehũa pessoa do mũdo. Entom de todo en todo pollo meudo contou a este senhor o caso de ponto a ponto, ao qual ora beesse dello mal o bem o seu coraçom nõ sse podia encobrir que lhe nõ disesse todas suas ynfortunas que antes padeçera.

E de aquí adelante començó de contarle grandes cosas que en su coraçón tenía encubiertas que fasta estonçes nunca a ninguno las descubriera, contándole otrosý los grandes travajos e dolorosos casos que avían por ella pasado. E commoquier que no supiese con quién ella fablava, no pudo detener en sý cosa ninguna que a este señor no la descubriese agora, viniese dello bien o mal.

En el capítulo XXVII, Apolonio, llegado a Tarsea, pide a los notables de la ciudad que le oigan su queja legal. El texto castellano, fiel, añade motu proprio una amplificatio:

A qual cousa per ante todos notificada, el, como homẽ que desiaua paz e nom guerra, rrogou a aquelles da çidade que lhe fezessẽ dereito delles.

La qual querella e maliçia asý ante todos publicada, él commo onbre que deseava pas e non guerra, rrogó a aquellos de la çibdad que le fisyessen justiçia dellos e derecho, e que en lo asýfaser que farían bien; en otra manera que creyesen que los guerrearía muy cruelmente.

Más abajo, en el capítulo siguiente (XXVIII), de nuevo Juan de Cuenca se permite modificar y ampliar el texto, sin perder el sentido:

... spidiose dos de Tharssya e tornousse outra uez pera seus nauyos. $O$ uento era mũỹ boo e o mar prano, ẽ tãto que nom lhes fazia mester de tirar soo hũa moneta do treu, ataa que chegarom aa çidade de Penthapollym.

...despidióse de los de Tarsea e fuese a Tíro e acomendó a Dios a sus fijos e aquel rreyno. E después mandó adereçar navyos e él e su muger entraron en ellos e aviendo buenos vientos e la mar a su voluntad bien aplacada, syguyeron su curso en pas e sosiego e llegaron a la çibdad de Pentapolín.

También en este mismo capítulo, al final de la narración y antes del diálogo entre el Confesor y el Amante, el texto castellano añade la frase «donde con mucho plaser bivieron e ovieron fijos de bendeçión, no seyendo agraviados de 
parte ninguna». A este mismo orden pertenece la amplificatio de la frase siguiente:

Para ora mentes quãto bẽ vem ao homem que leua boo fundamento.

Para agora bien mientes e mira a los onbres que biven e su fundamento es bueno, quantos bienes e onores an de Dios.

La dificultad del concepto mismo de buen/mal amor hace que Juan de Cuenca se sienta necesitado de expandir el texto portugués:

Por esto, filho meu, tu podes aprender que cousa he amar em boa maneira e em outra guisa.

Por esto, fijo mío, puedes bien entender quánto es bueno amar bien o mal, e qué cosa es amor bueno o no, e el amor qué cosa es en buena manera o no.

El único error de peso que encontramos ocurre al final casi del texto de la Historia de Apolonio, en el diálogo entre Confesor y Amante que precede el Epílogo final de la obra en que se discute la esencia del buen/mal amor. Allí Robert Payn traduce correctamente el Danger del original inglés por Daũger. Parece, sin embargo, que Juan de Cuenca encuentra dificultoso el neologismo del inglés y modifica el texto (aunque en el libro III lo había traducido por No Querer y Mal Querer):

Mas deste ponto soo me posso bem scusar, que eu ataaqui nũca endoudeçy, saluo naquelle onrrado logar onde todo delleytamento e toda graça he posta, se aquel maao bischo Daüger nom fosse. Ca eu nom sej a que chamades Fortuna, mas que Daũger he eu o hey mũỹ bem prouado.

Mas, deste punto, sólo me puedo bien escusar que fasta aquí yo nunca fuy enamorado, sy no en aquel lugar onrrado donde todo deleytamyento e toda graçia es puesta, sy aquel mal traydor de mugier no estouyese ally. Ca yo non sé a qué llamaes Fortuna, mas quién es el no querer, yo lo tengo bien prouado.

Ya en el Epílogo, la primera rúbrica muestra la adaptación a que Juan de Cuenca somete el texto para su audiencia específica:

[Capitulo XXIX] Acabada a confissõ, o Confessor Genius deu sãao consselho ao Amante segundo a ele era mais conpridoiro.

Cómmo acabada la confisión, el Confesor Gimýnez dio sano consejo al Amante, según que le hera conpljdero.

En el capítulo XXXIII Juan de Cuenca se permite una amplificatio para aclarar, pensamos, el sentido del original.

Porque dhũa cousa sey çerto, que os que queriam e nõ podem ao tenpo dagora nõ som amados; e porem, ante que tu em amor faças taaes prouas queiendas tu 
entendes que nom podes acabar, mjlhor te sera no começo de fazer hũu fermoso rreteer?.

[...] quales entiendas con ellas no poder saljr, mejor te sería de fazer tu juego, manna, e que te rretraygas fermosamente.

En el mismo capítulo, hay un error de lectura. Así, al portugués «Ca, posto que tu podesses chegar ao teu amor» se hace corresponder un castellano «Ca puesto que tú pudieses llenar al tu amor».

Caso diferente de amplificatio se produce al fin del capítulo XXXIV Así, al portugués «E aallem desto a mayor parte dos que fallauom, segundo eu entendy, foy de feito darmas e caualaria, e que cousa he de jazer em braços ao tenpo que o homẽ tem cobrado seu amor» se hace corresponder el siguiente texto:

[...] en braços de su amiga el tiempo que onbre tyene cobrado su amor $e$ se falla tanto querido commo él quiere.

En el capítulo XXXV, donde se nos presenta el típico catálogo de enamorados de la tradición cortés, los nombres de los mismos quedan en muchas ocasiones más cercanos al original (inglés) en el portugués que en castellano, aunque por motivos de espacio no podamos extendernos aquí en más pormenores. Valgan de muestra «Gymor» (Ginebra), del inglés «Gunnore», que en castellano da «Ginebra». O el portugués «Gallaot», del inglés «Galahot», en castellano «Galeote».

Dentro de este mismo capítulo se produce otro error de Juan de Cuenca. Así, el texto portugués «Vy outrossy aquella Deyamyra, que Achilles desenparou quãdo Diomedes, per mandado dos gregos que jaziam sobre Troya, por el ffoy. Antre as outras muytas que hi stauom sobre o prado uerde vy aquella doorida Rraynha Cleopatla, que por amor de» da lugar a lo siguiente:

Vy, otrosy, aquella Deydamya que Archiles...que yazyan sobre Troya, pero él fue con otros muchos que ay estavan sobre el prado verde. Vy aquella rreyna Cleopatra que, por amor de...

En el mismo capítulo, al hablar de Alçiona se menciona que fue mujer de «Scix» (inglés «Ceix» 0 «Seyix»), nombre que deja sin traducir el castellano, posiblemente por no entenderlo.

En el capítulo XXXVI, Alvar indica que existe una parte de columna en blanco, sin texto:

Et los que tal opinión touyeron... [f. 406va] tal lánpara ayna.

Ello es una prueba más de que debieron existir más ejemplares del texto portugués que el ms. de Palacio, pues en él no falta dicha lacuna:

E esta opinyõ tynham algũus delles. E outros diserom que arreuatada braueza dAmor ẽ a ujda do homẽ nõ sguarda hidade algũa, porque, em quanto hi ha

\footnotetext{
7 De hecho Payn está traduciendo un original inglés que dice «beau retret».
} 
azeite pera queymar, a llanpada mũỹ de ligeiro se açende de tal fogo, que aadur se apaga, saluo...

El comienzo del capítulo XXXVII proporciona otro caso curioso de amplificatio, sin que pueda descontarse corrupción del texto base:

[A]quel que quiser parar mentes aos tenpos do ano, começando des março ataa que o mes dagosto seia passado, pode trazer aa sua rrenenbrança a condiçom da poderosa mançebya; ẽ o qual tenpo o ano dentro en ssy toma allegramento das heruas, flores, folhas, fruytos, pãaes e huuas e bynhadas.

[A]quel que quisyere parar mjentes a los doze meses del anno, començando desde el mes de março fasta febrero, et asy de las yervas e flores et fojas e frutos, panes e huuas e vendimyas.

En el mismo capítulo, Juan de Cuenca se permite variar el texto por mor de un prurito estilístico:

«Senhora», disse eu, «a mĩ nenbranra bem de lhe dizer esto que me auees dado por encarrego.»

«Sennora, bien me plaze de fazer esto que me mandáys».

En el último capítulo, se produce una considerable diminutio, no creemos que motivada por falta de comprensión:

Porque a natureza del he en ssy tam desuayrada, que do mũỹ muyto e do mũỹ pouco senpre tem algũa contrariedade, en tanto que nehũu homẽ sem algũu fallimento pode ẽ el conpridamente auer seu deseio

...que su naturaleza [de Amor] es en sý tan desvariada que de mucho o de poco no hay alguno que no esté quexoso.

Por último, y sí ahora debido a la necesidad de glosar o explicar un original portugués algo oscuro, se produce esta modificación unas líneas más abajo:

Mas aquel amor que no coraçom de homẽ sta fyrmado sobre caridade nõ he pera rreprender, mas he pera mereçer guallardõ do bem en todo llogar, por quãto tem en ssy contrapeso per que a conçiençia possa seer carregada.

...en todo lugar, porque tiene el peso de la conçiençia.

Como puede apreciarse, nada en estos ejemplos aducidos lleva a pensar que la traducción de Juan de Cuenca sea nada menos que fidedigna. Su buen oficio, sin embargo, no es óbice para que en ocasiones no entienda alguna palabra o expresión, para que la calidad del ms. original le impida traducir con exactitud alguna palabra o frase, o para que motu proprio decida modificar (ampliando, reduciendo) el original cuando así lo considere necesario. De nuevo, capítulo aparte son los lusismos semánticos y sintácticos del castellano, más abundantes de lo hasta ahora señalado, aunque aquí no podamos entrar en ello por ahora. 
El libro VIII contiene dos elementos de enorme interés para los estudiosos de la literatura peninsular. En primer lugar, la História dApolónio, de sobra conocida y resumida de manera sucinta por Deyermond (IX):

The King of Antioch seduces his daugther. Apollonius of Tyre discovers the guilty secret and has to flee for his life. In years of wandering, he meets and marries a princess, who seems to die in childbirth. Their daugther escapes murder by her foster-mother, is abducted by pirates, and is sold into prostitution, but saves herself by her quickness of wit. She and her father are reunited, the lost mother is found, the guilty are punished, an Apollonius and his family reign over three kingdoms.

Dicha fábula procede de la Historia Apolonii regis Tyri, y de esta obra habrá varias versiones, en latín, en la Edad Media, siendo las de más fama las incluidas en el Pantheon de Godofredo de Viterbo (c. 1120-1191) y en la Gesta Romanorum (s. XIV), ejemplo 153. La versión de la historia que Gower incluyó en su Confessio Amantis procede, aun con algunos elementos del Pantheon, de la Historia Apolonii regis Tyri, así como, obviamente, sus traducciones peninsulares. En castellano dicha historia ya había hecho su incursión medieval a través del Libro de Apolonio (s. XIII), en cuaderna vía, y quizá de la versión en prosa programada para la parte V de la General Estoria alfonsina (f. s. XIII) (el final de la parte IV la anuncia). A ello siguieron la Historia de Apolonio que es parte del libro VIII de la Confessio en la traducción de Juan de Cuenca (h. 1450), y el incunable Hystoria de Apolonio (Zaragoza: Pablo Hurus, 1488), editado por Deyermond. Ya en el s. XVI el Patrañuelo (1567) incluye la historia en el cuento $\mathrm{XI}^{8}$.

En segundo lugar, la parte final de la Confessio (final del libro VIII) incluye lo que podríamos llamar un Epílogo. Éste consiste en un diálogo entre el Confesor (Genius-Gimýnez), Venus y el Amante en que se remata la doctrina del libro en su conjunto. Hasta ahora el libro ha seguido el plan de una confesión general, aderezada con multitud de excursos, ya sean exempla apropiados y mostrativos de cada vicio (o su virtud de contrapartida), ya sean digresiones de tipo enciclopédico (aunque sin nunca perder el tino confesional [enseñanza moral, discere ad facendum] que da marco a la obra). En el contexto de la literatura de amor cortés peninsular, y más en concreto de la incipiente literatura sentimental, dicho Epílogo es importante. No olvidemos que el Siervo libre de Amor, primera obrita canónica del género, sigue precisamente también un modelo confesional (dentro de un marco epistolar y con aderezos consolatorios ausentes en la Confessio). Y es con esta obra con la que debe compararse sobremanera la Confessio. El Confesor desde el comienzo del Epílogo asienta la conversación sobre el carácter racional/irracional del amor: «Porem de marauylhar he que tal cousa [o Amor] pollos homẽes que ssom rrazoauees seia deseiada.» También como en el Siervo posterior, la rección de sí mismo, y en particular la rección del juicio, será motivo central de la discusión de amore, centrándose, pues, en términos escolásticos y tomistas: «...scilicet se el mal rreger o rregno de sseu juizo

${ }^{8}$ Remito a Deyermond para un estudio breve de la fortuna de la Historia Apolonii Regis Tyri y las diferentes versiones latinas y vernáculas medievales y renacentistas (IX-XV). 
sera aazo de perder ssy medes. $\rangle^{9}$ Amans decide, confiado en que es natural amar, pues a los seres naturales él ve que Amor posee algún tiempo del año, escribir a Venus una supplicatio («Suplicaçom»), pidiendo que le aclare el modo en que naturaleza le manda amar, pues su entendimiento no es bastante para hacerlo, ni aunque pelee con su voluntad «nõ posso sseer apartado damar». En todo este fragmento los términos Juicio, Entendimiento, Corazón y Voluntad, potencias del alma, funcionan a modo de casi-personificaciones, como en el Siervo. También como en el Siervo (y tantas otras obras de amore) se queja el Amante de que el amor que experimenta es una sensación antipacífica, insistiendo en otro tópico de la literatura amorosa (y de amicitia) que habla de amor/amicitia como prototipos de paz, concordia, equilibrio y felicidad ${ }^{10}$. Una vez concluido el dic-

${ }^{9}$ En el libro V (capítulo IV), al hablar de los celos, ya había dejado sentado que Amor es una enfermedad de la fantástica: «Que esta febre de ceumes procede da doudiçe dAmor e parte da desffiança. Porque, assy como o enfermo que he enfastiado auorreçe a uyanda quãdo a uee, bem assy a enfermidade desta febre que he aazada da fantasya faz o çeoso star ẽ forte ponto. Ca a fỹgida enfformaçõ causada per sua ymaginaçom de todo seu amor faz perder o apitito». Ver infra también, nota siguiente.

${ }^{10}$ En la Confessio, se recordará, el Amor queda definido como pasión irracional y excesiva. De ahí que uno de los tratamientos más elaborados en la obra del tema del Amor se produzca en el libro VI, dentro del epígrafe de "guarguantoyçe», y aun — dentro de ésta- en el de "dylycaçya» ( «Aquy tracta daquella speçya de guarguantoyçe que he chamada dylycaçya»):

Amante: «Padre meu, digouos que nos delleytamentos dAmor, polla guisa que uos ora auees dicto, nũca ataa fym ataaquy fuy culpado. $\mathrm{Ca}$, se eu tal molher ou amiga teuesse como uos dizees, nũca sobre outra lançaria meu coraçõ, porque em fazendoo eu seria sobeio. Mas por mỹgua do prazer de tal fartura de molher, ou doutra amiga algũa, eu ataaquy stou jagũu e nom posso achar mantimento. Assy que, por nõ teer as uyandas dillycadas con que os coraçõoes ssõ manthũdos, eu cada noite me lãço na cama ssẽ comer. Mas se eu podesse tanto guaançar de mynha senhor que ella do sseu boo senbrante me quisesse auondar, aynda que me mỹguasse todo o al, o meu coraçom pollo tenpo en parte seria contento. Do que, padre meu, ela faz muyto o contrairo, como aquella que, aynda que eu ouuesse de morrer, com hũu soo oolhar nom allegraria este meu coraçom. Assy que quanto por tal cozinheyra queianda ella he eu pera ssenpre andarej jagũu. Ca, çertas, se noio ou pesar pode manteer o coraçom dalgũu homẽ, eu dello tenho sobeio ao jentar e aa çea, mas tal byanda como aquella he tam dura de sua naturaleza, que o meu stamago per nehũa maneyra ha poder de a smoer. Ex aqui o delleytamento damor con que o meu coraçom de noyte e de dya he manthũdo. $\mathrm{E}$, pero que eu do que hej mester som muyto fallydo, nõ digo porem que em algũa cousa nõ seia culpado em este uiçio, ca, sse eu ẽ amor nõ achasse algũu conforto de tomar em el prazer, de todo ficaria mate. $\mathrm{Ca}$, posto que eu conpridamente nõ sento o tallantoso gosto damor, com outros sabores pequenos que eu furto apago mjnha fame pollo tempo. Nom ssey se uos, padre, sabees o que eu queria dizer».

Confessor: «Filho meu, destes bocados preçados en que o teu coraçom aas uezes he manteudo confessate bem e logo o descubre».

Amante: «Padre meu, dizeruos hey en como mynhas manteenças cãae cada hũa em seu degraao. Hũa manteença he do que eu ueio. Outra he do que eu ouço. A terçeyra naçe do meu penssamento, ca doutra guisa eu nõ fora agora byuo. Porque a aquel que mỹgua a mãteença do sseu coraçõ nõ pode bem scapar a morte. A mynha primeira manteença he da uysta, porque o meu olho de todallas boas cousas tem o que assy he concordãte, e das abastosas manteenças que eu hey assy he quãdo uou a algũu logar onde posso ueer o rrostro da mjnha senhor. $\mathrm{Ca}$ entom os meus olhos, posto que muyto auorreçem de jaũiar, começam dauer fame, en tal guisa que lhe pareçe dhũa ora tres ataa que eu alla uaa e que elles a ueiam; e entõ, segundo o que elles ham, toma o apetito sua manteença de tal deleytamento que nom ha mester doutras cousas preçadas mais que daquellas bistas 
tar de la carta, Genius la entrega a Venus, a quien el Amante de repente ve aparecer: «By subitamente Venus star açerca de mỹ a sso hũa aruor uerde.» Recuérdese a este respecto la importancia del color verde en el Siervo:

La primera parte prosigue el tiempo que bien amó y fue amado; figurado por el verde arrayhán, plantado en la espaçiosa vía que dizen de bien amar, por do siguió el coraçón en el tiempo que bien amavau ${ }^{11}$. La segunda refiere el tiempo

desuayradas en que sse mantem. Ca elles stam oolhando o sseu rrostro, que de collor he mais fresco que nehũa frol; vem a sua fronte larga, lysa e sem uerrugamento; bẽe os seus olhos, que semelham hũu parayso; vẽe os seus beyços uermelhos cõ queixo concordante ao seu rrostro; assy que quanto bẽe todo he cheo de graça. Veem as suas mãaos fermosas e lynpas e o sseu collo rredondo en que osso nẽhũu pode pareçer. E porque elles todas estas cousas podem beer, mas sem prasmo nehũu, a manteença dos olhos sentem muyto mayor delleytamento. Vẽe outrossy o sseu talhe com cos rredondo e Delgado e de onrrados apostamentos guamydo, que passa todollos prazeres do mes de mayo, quãdo com doçes chuyuas de fermosas flores he uestido. Com taaes bistas como aquestas os meus olhos som manthudos. [...] Doutra parte, muytas uezes aconteçe que a mynha orelha rreçebe en ssy boa pitança ẽ leendo a cronyca de Jdoyne e dAmadas, que em outro tenpo steuerom ẽ o caso que eu ora stou. E esso meesmo doutros mũỹ mujtos que ante que naçesse forom namorados, porque, quando do sseu amor ouço dizer, a minha orelha cõ prazer da storia que assy ouve aas uezes traz a mjnha memoria ẽ como noio nõ pode senpre durar. E asy entra sperãça cõ de cabo ẽ uez doutro mantimento que nom posso auer. Mas esto dura tam pouco como faz a festa das cereyias no mes de junho. Pero aĩda polo tenpo o meu coraçõ cõ ello fica contẽto, porque cõ quaeesquer palauras de prazer que a mynha orelha ouue a uõtade ẽ parte xe me contenta e en logo doutra biãda he meu mantimento. Ex aqui, padre meu, como eu por ueer e ouuyr hey tomado mujtas uezes mũỹ grã deleytamento e prazer. Os quaees dous ẽ meo de meu coraçõ fazem ao terçeiro tomar seu lugar e hi aparelham a tallantosa manteença, a qual de noyte a mỹ conuem de prouar, quãdo ueer e ouujr som de mỹ allongados. Ca entõ o tallantoso cozinheyro que he chamado Pensamento he prestes pera fazer a mjnha sobreçea, da qual o meu coraçom por entom rreçebe seu mantimento. Este cozinheiro as palauras dAmor tem sobre o fogo, que com Fãtasya e Deseio senpre feruem, das quaees, jazendo eu na cama, o meu coraçõ muytas uezes he mantheudo, e entõ el põe sobre a minha mesa as praziuees bistas e pallauras que eu ẽ antes by e ouuy. Mas, enpero, a mjnha festa nõ he porem conpridamente chea como eu queria, ca as yguarias que ante mỹ som apresentadas som pratees cheos de deseios e de quereres, mas de sentyr ou de gostar nũca pude auer tã ssoomente hũu bocado. E, porem, assy como dito hej, de çyma eu sobre o espinheiro lanbo o mel, e per tal modo mascho o freo que em effeito toda mjnha manteença he em uãao. $\mathrm{Ca}$, assy como o homẽ sẽedo doente se queria saluar per meezinha, bem assy eu me trabalho quanto posso pera apagar a fame do Amor que eu padeço. E cõ esto passo meu tẽpo ataa que uenha aquella grande festa que toda mjnha fame podera fartar. Ex aqui os meus tres prazeres, scilicet ueer, ouuyr e penssar, e a maneira ẽ como eu soo mantheudo sem gostar ou ssentyr. Ca assy como o fusello byue pollo aar, assy faço eu, e çerto, porem, que tal deleytamento como aqueste nõ me faz usar de guarguãtoiçe. Pero, meu sancto padre, do que errey em este biçio de dillycaçia o corregimento dello encomendo ao uosso boo siso».

11 «El arrayhán es «(Myrtus) arbolcico oloroso e templado que en romance dezimos murta y en aráuigo arrayhán» (Vocabulario eclesiástico, Admyte II, p. 227). Como indica el De proprietatibus rerum, produce - junto al romero y el almizque - un humo puro al ser quemado, oloroso y de muy presto movimiento (Admyte II, p. 605). Para el «fluxo fecho poco a poco sin vicio de humores» el Lilio de medicina recomienda el olio de arrayán (Admyte II, p. 82), así como para el dolor fuerte de cabeza (ibid., p. 97), para el insomnio, como purga para el riñón y la vejiga y para disolver la piedra del riñón (especialmente en los jóvenes, que son calurosos e inclinados al amor). Hernán Núñez de Toledo indica que está consagrado a la diosa Venus: «Son consagrados a esta diosa entre 
que bien amó y fue desamado; figurado por el árbor de paraíso, plantado en la deçiente vía, qu'es la desesperaçión, por do quisiera seguir el desesperante libre alvedrío. La terçera y final trata el tiempo que no amó ni fue amado; figurado por la verde oliva, plantada en la muy agra y angosta senda, qu'el siervo entendimiento bien quisiera seguir, por donde siguió, después de libre, en compañía de la Discreçión ${ }^{12}$.

Venus, a modo de dea ex machina, pero asimismo quizá con ciertas connotaciones de Sindéresis (figura relevante en el Siervo), pronuncia que Amans sera liberado o sanado de su dolencia: «E aynda que ella [hũa meezinha] tal nom seia como tu per uẽtura querias, pero ella sera queienda a naturalleza dAmor segundo Rrazõ deue sseer concordante.» Venus a continuación reprende al Amante por perseverar en amor siendo ya de edad avanzada, insistiendo con ello en otro tópico de la literatura amorosa medieval ${ }^{13}$. Y no se olvide que esta pers-

los árboles los arrayhanes, entre las aves las palomas. Llevan su carro ciznes» (ed. Weiss \& Cortijo, fol. 46v; eHumanista, www.spanport.ucsb.edu/projects/ehumanista). Uno de los epítetos de Venus era Murtea» (Cortijo ed., Siervo libre de Amor). Sobre Venus, en el largo excurso enciclopédico del libro VII de la Confessio, se dice:

Do terçeyro planeta, que he Venus.

«[E]m çyma de Mercurio o mais chegado planeta he Venus, cuia constullaçom gouerna todollos namorados, posto que elles guãaçẽ seu amor ou nom. Dos quaees eu entendo que tu es hũu. Mas a qual parte te ha de trazer a tua uentura na fym, per este planeta te sera mostrado, assy como o ella tem feito a mujtos outros, dando a algũus prazer e a algũus noio. Mas ẽpero a condiçom deste planeta he mais ỹclinada a dulçura que a amargura, porque aquel que so ella açerta de naçer a ssua naturalleza deseiara prazer e allegria; sera gentyl e cortes e omjldoso, fallando suas pallauras mũỹ mesuradamente. Aallem desto, onde quer que achar prazer ẽ amor o sseu coraçom exçitara que o uaa buscar, como aquel que en ssy sera tãto amoroso, que nas cousas que perteeçẽ a Amor nõ sabera que cousa he uiçyo. Porque aquel que for natural veneriano, per uya de naturaleza senpre seguyra esta ley, a qual he hũa das rrazõoes prinçipaaes por que Uenus foy chamada deessa dAmor».

La casa de Venus es Tauro, como también se recuerda en el libro VII:

[O segundo syno, que he Tauro.]

«[T]aurus depos este he o ssegũdo syno, a figura do qual he semelhante a hũu touro, mas a ssua naturalleza he seca e fria e, segundo os liuros dam thestemunho, el he casa do planeta Venus e em parte descordante. Este Tauro cõ çertas strellas he figurado no çeeo, pollas quaees se mostra que tem os cornos atados ao cabo dAryes e nos peytos tẽ dellas xbiij e sobre o cabo tẽ outras mais. A este syno he apropriado o mes de abril, cuias chuyuas amenystrã camjnho per que as flores aqui na terra sõ naçidas».

${ }_{12}$ Se cita en texto del Siervo por nuestra edición en vías de publicación (Madrid, Castalia).

${ }^{13}$ Recuérdese a este respecto que Boncompagno da Signa ya había unido los motivos de literatura visional de amore, diálogo autor-Venus en visión amorosa, literatura de tema de amicitia y burlas contra la vejez enamorada. Ver Cortijo \& Blecua. En Rota Veneris, que conviene analizar en el contexto de la Confessio (Cortijo 2001b), Venus cumple una función semejante a la que tiene en el texto de Gower, aunque allí el edicto final de la misma sea decididamente pro amore, no como en la Confessio:

[15.1] Venus habla a todas las mujeres de esta manera. [15.2] «Agradables os son las palabras que ya hemos escrito en nuestra Rueda del amor y con las cuales se pueden visitar unos a otros revelándose los secretos de sus corazones. Sin embargo, en nuestra intención de dejar situado este espejo amoroso que escribimos en lugar más eminente, hemos notado que este último capítulo es algo defectuoso y con nuestra autoridad queremos ofrecerlo íntegro y sin tacha, enseñándoos a encontrar las oportunidades para el amor y por medio de qué personas podáis hacer esto, así que con esta intención 
pectiva de la escritura del tratado consolatorio de amor desde el momento del desamor (y la edad madura) será la utilizada igualmente por el Siervo. Tampoco puede perderse de vista que la importancia de Venus en la Confessio está en paralelo a la presencia constante de Venus en el Siervo (allí desde las menciones a la «venera del alvo crystal,» «la çibdat de Venera,» «la antiga çibdat de Venera,» etc.). Tras la visio Deae, típica del imaginario amoroso (donde se hace una extensa glosa sobre 'Cupido' y sus flechas [otro episodio necesario en todas las novelas sentimentales hispanas]) sigue una aparición de Cupido, que llega acompañado de «todo o mũdo de gentys homẽes que em seu tenpo forom namorados» (catálogo de amantes presente a su vez en muchas obritas sentimentales portuguesas, castellanas y catalanas) [ver Cortijo $2001 \mathrm{~b}$, Índice, para referencias a todas estas menciones en obras sentimentales]. El largo catálogo de enamorados que sigue debería compararse con el que aparece en tantos textos sentimentales hispanos (Cortijo 2001b). Por ahora señalemos que la frase «Ally by ẽtom a guisa noua de Boemya cõ desuayradas obras mũỹ bem deuysadas» - y que Alvar recuerda (nota 233) que sirvió a Macaulay para indicar que el nuevo atuendo llegó a Inglaterra procedente de este país - quizá deba ponerse en relación, por lejana que se quiera, con la mención a «Boemia» en el Siervo. Tras unas discusiones entre enamorados sobre la mejor solución para curar la «doudiçe» del viejo amador, a éste le parece «que [Cupido] tyrou fora de mỹ o dardo queymante con que elle em antes passara o meu coraçom». Venus se acerca a curarle, le aplica un ungüento y le ofrece un espejo en que él se ve encanecido, sin color y de ojos tristes. Por fin la Razón, «depois que fuy tornado a meu acordo, ...se uino direito pera mỹ e lançou fora do meu coraçom a doudiçe e fantasya de que me eu em antes querellaua.» ${ }^{14}$ Curado, pues, de la locura de su fantasía, Amans pide al Clérigo que le absuelva, lo que éste hace presto.

os ofrezco esta breve regla que nunca falla: todas pueden dar rienda al amor en mil maneras, las viejas por sí mismas, las monjas y viudas bajo color de religión, las casadas mediante las viejas y doncellas, y las jóvenes mediante todo lo susodicho; ítem más, que no hay nadie tan inteligente que pueda impedir siempre el deseo de una mujer». Dicho esto, condenó a los sacerdotes y a todos los que están tocados del vicio de los celos, añadiendo por demás que quienquiera que dude y quiera convencerse de ello recibirá sin duda alguna una corona de espinas con un mote grabado que consista en el verso del cuco y en el que esté pintada una calabaza de huerta (Antonio Cortijo Ocaña, http://dobc.unipv.it./scrineum/wight/rota.htm).

14 Ahora es el dardo de amor (siguiendo el motivo de Ovidio en sus Metamorfosis) el que Venus saca del corazón del Viejo enamorado. En el libro VI (ver supra nota 3) el Amor se contagia al beber un bebedizo del tonel de la bodega de Júpiter («Aqui conta, segundo o poeta, dos dous tonees que tem Jupiter em sua adega, dos quaees hũu he cheo do beuer doçe e o outro damargoso»), y con él se relaciona más Baco que Cupido (siendo éstas las dos genealogías amorosas que aparecen en la Confessio). Los que siguen son los ejemplos de bebedizo de amor del libro VI, que, junto con el Epílogo, constituyen algunos de los capítulos más teóricos de amore de la Confessio (junto con el comienzo del libro I):

Nota aquy en como per aazo da oraçom o beuer aas uezes he tragido ao que ha sede, e conta por enxenplo o que aconteçeo a Bacus na terra de Lybea byndo dhũa batalha que antes ouuera nas partes do Ouryente.

«[E]ste Bacus, filho de Jupiter, andãdo em guerra longe no Oryente per mandado de sseu padre leuou consigo mũ̃y gram poder, onde assy xe lhe açertou que ouue uyctoria de seus ẽmjgos e tornousse com grande õrra per hũa terra seca perto do rreyno de Lybia. E aconteçeo hũa tal auentura, 
Venus, sin embargo, antes de macharse, le amonesta de una manera semejante a como imaginamos que debió producirse el diálogo final Sindéresis-Juan Rodríguez, cuando aquélla se presenta para salvarle en su barca (nótese las frecuentes menciones a «camino», reflejado luego en las «vías» de amor del Siervo):

que nom podia achar augua nẽ outro lycor con que sua sede podesse apagar, por a qual cousa el e sua gente toda per mỹgua de beuer stauam ẽ põto de seerem destroydos. Bacus, ueendo aquesto, começou de rrogar a Jupiter, dizendo em esta guisa: «Oo alto padre que todo uees e a quem he rrezõ de rrogar e pidyr ao tenpo da neçessydade; para mentes e ordena maneyra en como esta sede que auemos seia apagada e outorganos que possamos chegar em saluo aa terra õde nossas senhores stam aguardando nossa bjnda». Dictas estas pallauras, a sua oraçom ante os seus deuses foy ouuyda, e logo per ante seus olhos pareçeo hũu carneyro que com as mãaos staua scauãdo a terra, e fez hi naçer hũa ffonte dhũa augua mũy fresca e clara, da qual el e todollos da sua oste fforom auõdados como elles quiserom. E por esta graça que lhes entom assy aueo Bacus naquelle lugar hũu tenplo mũỹ rrico mandou fazer, por tal que os que ham sede quãdo <ouuyssẽ ou uessem> [o uessem ouuyssẽ] pera ssenpre dello rrenẽbrança. Porem, filho meu, por esto que entõ assy aconteçeo deuyas de parar mentes e rrogar ao tenpo do mester, como fez este Bacus, e penssar en como ele braadando per graça ouue e cobrou graça, entendendo na tua uõotade que aquel que o assy consselhou nom era sandeu. Outrossy sabe por çerto que o mũdo poucas uezes guãaça algo e que pallauras ham en ssy grande uirtude. E porem, por tal de apagar a tua sede, nũca leixes de fallar, mas pidir e rrogar, tarde e çedo, penssando senpre no que te eu disse, en como o copeiro que traz a chaue he çego e que se sse asy aconteçesse per caso que el da parte çega abrangesse o tonel doçe, que entom auerias o doçe e talantoso beuer per que a tua beuediçe em amor seria tenperada. Per esta guisa te consselho eu que tenperes o teu coraçõ em sperança de percalçar mais asynha graça, ca aquel parte quer que beuediçe se rreuolue senpre faz o homẽ entropeçar e muytas uezes cahyr onde nom ha poder de sse nũca mais leuantar».

Aqui por enxenplo da beuediçe dAmor conta em como Tristam por hũu beuer que lhe foy dado se enbeuedo por amor da fermosa Ysollda.

«[E] por que tu ueias desto euydençya prouada, antigamente per uerdadeira experençia a todallas gentes he notorio en como Tristam, per aazo dhũa beueragem que lhe foy dada per Brangem, por amor da fermosa Yseu foy beuedo ẽ amor ante que El-Rrey Marco, seu tyo, tomasse por molher, segundo depois foy bem sabudo. Aallem desto, filho meu, se tu das cousas que ia aconteçerom em amor quiseres mais saber, e spiçialmente en como beuediçe he muyto de squiuar, per as cousas que de feito se açertarom em outro tenpo hũu grande enxenplo te quero ora dizer, por tal que da conpanhia dos beuodos mjlhor e mais asynha te possas senpre afastar».

Aqui falando dos perigoos que uẽe da beuediçe dAmor e conta hũa storia de Pyrotous e doutros que forom chamados Centaury [sic], que elle conuydara pera o dia da uoda.

«[A]chasse <em> scripto em storia poetyca daquella molher Ypotiçia, de cuja fermosura os homẽes que morauam na terra hu ella staua muyto fallarom. E assy foy que Pyroteus per tal modo encamynhou seu feyto, que el com ella auja de casar, de que o sseu coraçom era mũỹ ledo. E por tal de conprazer aa sua uoontade della, conujdou<ho $>$ pera o dia da uoda per pallaura e per messagẽ todollos amigos que elle auya. Assy que aquel dia fez grãde festa e aos seus conujdados grande onrra. E segundo diserom sposou cõ aquela senhor, a qual aynda entõ era molher noua. [...] E Bacus outrossy abryo entom hũu tonel, de que os mayores da conpanha per bya de beuediçe fora de rrazom stauã uençidos. E Uenus, querendo poer mãao neeste feito, deulhes de beuer daquelle uaso que sperta a uõtade, per que o homẽ dentro en ssy se delleyta. E assy, seendo elles contoruados de dobrada beuediçe, o fogo do deseio os fez tã fora de sy e tam furyosos, que nehũa rrazõ em elles cabya, como homẽes que em outra cousa nõ penssauõ senõ en aquella fermosa donzella que entom casara. Assy que estes, que per nome erã chamados Centaury, seendo todos dhũu acordo, per fforça leuarõ a noyua conssygo, como aquelles que outro sguardamento nõ auyam saluo a beuediçe en que stauã. A qual ha feito muyto mal a muytos, assy em amor como em outra guisa [...].

Aqui em speçial falla contra aquelles que per costume do muyto beuer som a meude beuedos, e conta sobrello hũu enxenplo de Gualba e de Bitello, dous prinçipes que forom dEspanha. 
Por ende, tu nom tees senom hũu camjnho soo, em o qual conpre que Rrazõ seia tua guya. Porque aquel que nom uee o perigoo ante que uenha mũỹ asinha, perdera sy medes por mjgua de boo rregimento. Por esto, filho meu, sey senpre auysado e nom te squeeça a sentença desta doctrina que te ora direy. Nom enpaches mais a mjnha corte, mas uay buscar õde uirtude moral tem sua morada, segundo eu ouço dizer que nos liuros de lõgo tenpo tees studado faz mençõ. Ca digote por çerto que sse o camjnho da tua saude quiseres catar, nõ te conpre de fazer segujda sobre feito que nom he pera poer em pro, porque nehũu homẽ por o querer fazer seia tam desauysado. Porẽ, para mentes a esto que te ora rrazoo e nẽbrete en como, segundo a geeral husança da mynha ley, tu e eu somos hordenados de nũca ia mais comunycarnos em feito damor.

Nada queda para concluir. Pero antes de marcharse Venus gusta de juntar en uno realidad y ficción (como el Siervo), haciendo que el Amante prometa hablarle a «Chauçer»: «Dilhe que lhe enuyo dizer que elle em esta sua derradeira hidade, por tal de fazer fym de todas suas obras, trabalhe de fazer seu Testamento dAmor, assi como tu aqui has feita agora tua confissom». Los Testamentos amorosos, son, como es sabido, obras frecuentes entre los autores sentimentales,

«[L]eesse em cronyca de Gualba e de Bytello, naturaaes dEspanha, os quaees dous eram dos mais grandes senhores de toda a terra. $\mathrm{E}$, segundo a desposiçom da guarguãtoyçe e beuediçe, anbos yguaaes em condiçom. A qual conpanhia foy mujto maa, consyrando en como os homẽes que com binho ham costume de seerem beuodos nõ podem muyto durar, por quãto elles tẽe perdida aquella uirtude per que a rrezõ se deuya bestyr. E esto se prouou bem per aquelles dous. Dizem as gentes que antre beuediçe e sandiçe nõ ha defrença, e, uerdade dizendo, nehũa dellas he boa. $\mathrm{Ca}$ onde o binho desuya o entẽdimento Rrezom tem perdido o dereyto camynho, en tal guisa que el tã pouco teme dusar de quallquer uiçio que lhe uẽ aa uoontade, como çego polla claridade do ssol denfyar hũa agulha. Porque quãdo o homẽ com beuediçe he toruado, el por entõ nõ tem Rrazõ en poder, e por este põto soo Gualba e Bitello per sua culpa forom entõ anbos perdidos. E porẽ bem he que pares mentes ao que sobre esto te quero ora dizer. Estes dous senhores per desassysada exçitaçõ causada per sua beuediçe soiugarõ toda naçom do senhorio $\mathrm{dEspanha.} \mathrm{Ca}$, porque elles cada dia continoadamente eram beuodos, nõ auya hi uirgem nẽ molher casada en toda a terra, ora fossẽ fermosas ou feas, se lhes bem pareçessẽ, que elles nõ desonrrassẽ quãdo queriam. De que os que em ella morauã dentro en ssy ficarõ mũ̃̃ agrauados e nõ por outras muytas ssemrrazõoes que andauã obrando. Mas por conprido que o dia seia nõ seia porem de bĩr a noite scura. Ca Deus nom quis que elles muyto durassẽ, e por tanto hordenou maneyra en como elles per ordem de juizo fossem julgados a morte. E de como elles em antes erã enclinados aa beuediçe o sseu acabamento deu dello thestemunho; como aquelles que, por nõ sentyrem pena da morte, fezerom bỹr ante ssy hũu alguydar cheo de binho puro, do qual leuorom tanto, ante que o leixassẽ, que perderõ toda sua força e o entendimento. E assy seindo meo mortos com beuediçe matarõnos sem padeçendo gram pena. Filho meu, se tu em algũus pontos dos que hej ditos es culpado, per que os teus sentidos fossẽ desatados cõsselhote que os rreconçillyes outra uez pera tua casa».

Amante: «Padre meu, a todo meu poder o que dizees farey. Mas dũa cousa soo bem çerto, porque por muyto que me eu trabalhe darrancar de mỹ a beuediçe dAmor, nom quer a mynha Fortuna. $\mathrm{E}$, porem, se a uos a prouer de me dizer e declarar a ssegũda speçya de guargantoiçe de que uos ia fezestes mençõ, teeruollo ey em grande merçee».

Confessor: «Filho meu, fallando daquel uyçio que de todollos outros he ama prinçypal e he da conpanhia de Venus, a propriedade e condiçom te sera mũ̃ bẽ declarado segundo se mostra cada dia per experiençia per este lyuro adiante». 
desde alguna obra que puede calificarse de tal de Rodríguez del Padrón hasta San Pedro, entre otros muchos.

Difícil es decir de manera rotunda e inequívoca si ha habido un préstamo literario entre la Confessio (portuguesa) y el Siervo libre de Amor. Las tradiciones amorosas literarias que pueden haber tenido en común son muchas. Pero queden para la discusión posterior las concomitancias de motivos de confessio, peregrinatio vitae, amante maduro, rechazo racional del amor, entretejer de historias amorosas ejemplares, presencia de Venus (Discreción), disputa de Razón/Entendimiento y Libre Albedrío, «caminos» de amor, sendas «verdes» de peregrinación amorosa, influjo en ambas de la Peregrinación de Deguileville, etc. para sembrar la duda. Al fin y a la postre, el Amante mismo (como indica en el Capítulo I del libro VII) se denomina a sí Seruo dAmor:

Assy que a mjnha ujda he semelhauel ao que de suso dissestes, ẽ como o boy tira o arado por cousa que a el pouco presta. E eu posso dizer de meu cabo que per aquella medes guisa he despeso meu trabalho, porque quem quer que leue o prazer bem sey que eu tenho o cujdado, ca outrem me tẽ e eu nõ tenho cousa. E assy ssõ feito assy como Seruo dAmor.

Y, como decimos, las lecciones que de ambos libros se extraen son similares. El Siervo decide, a la postre de su peregrinación, abandonar el Amor (carnal) la lujuria; así Amans, quien tempera su deseo lujurioso (como se le aconseja al fin del libro VII), a pesar de que en el mismo libro se le enseñara que «[T]odo macho foy feito pera femea»:

[P]orende, o phillosopho, querẽdo dar a El-Rrey Alexandre sãao consselho sobre esta cousa, screueolhe que squiuasse senpre o ssobeio da luxuria e o tenperasse so tal rregra, que naturalleza rrazoadamente fosse contente, en tal guisa que ynorãçia dos seus delleytos nõ fosse aazo do sseu maao rregimento, per que el, na fim, como homẽ sem rrazom, fosse de todo derribado; porque, quando naturalleza he serujda do que lhe conpre, de rrazom deuya de sseer abastança de todo homẽ, se elle ẽ sy nõ he desujado do sseu entendimento.

Otro capítulo aparte es el de la relevancia que la Confessio (en su traducción lusa) tendrá para las letras portuguesas. No podemos extendernos aquí sobremanera, pero dejemos mencionado que del Leal Conselheiro y el Livro da virtuosa bemfeitoria al Boosco Deleitoso hay muestras en ella de la misma, en particular entre las obras que se escriben o proceden de miembros del círculo de Filipa de Lancáster y Dom Duarte.

Nada más dan de sí estas breves notas, por los límites de espacio. Sigue a continuación la edición completa del Libro VIII de la Confessio Amantis portuguesa, incluyendo el Prólogo, la História d'Apolónio y el Epílogo final a la confesión de Amans y al libro en su totalidad, que ocupa los fols.1v-26v en la foliación interna de dicho libro (233v-259v en la foliación total). 


\section{OBRAS CITADAS}

Alvar, Elena, M. Alvar, John Gower, Confesión del Amante. Anejos del Boletín de la Real Academia Española, 45. Madrid: Real Academia Española, 1990.

BIRCH-HIRSCHFELD, Adolf. Juan de Cuenca, tr..(Robert Payn tr.; John Gower). Confisión del amante por Joan Goer. Spanishce Übersetzung von John Gowers Confessio Amantis aus dem Vermächtnis von Hermann Knust nach der handschrift im Escorial. Leipzing: Seele, 1909.

BITAGAP (Bibliografia de Textos Antigos Galegos e Portugueses). Comp. Arthur L-F. Askins, Ainda Fernanda Dias, and Martha Schaffer (autores originales). (http://sunsite.Berkeley.EDU/PhiloBiblon/phhmbp.html).

Cortuo OCAÑA, Antonio, «La traducción de Juan de Cuenca: el minúsculo oficio del traductor». Revista de Poética Medieval. En prensa.

- «La Confessio Amantis en el debate del origen del sentimentalismo ibérico: un posible contexto de recepción.» En Actas del VIII Congreso Internacional de la Asociación Hispánica de Literatura Medieval (Santander, 22-26 septiembre, 1999). Santander: UP, 2001a. II: 503-601.

-, La evolución genérica de la ficción sentimental. Londres: Támesis, 2001 b.

-, «The Portuguese Translation of Gower's Confessio Amantis: O livro do Amante». Portuguese Studies 12 (1998): 1-6.

-, «The Complication of the Narrative Technique in 15th-Century Prose Literature on Love: The Somni de Francesc Alegre recitant lo procés d' una Qüestió Enamorada». Catalan Review 11 (1997): 49-64.

—, «La traducción portuguesa de la Confessio Amantis de John Gower», Evphrosine 23 (1995): 457-66.

Cortijo OCAÑA, Antonio, y Luisa BlecuA, Boncompagno da Signa, Boncompagno da Signa. La rueda del amor. Los males de la vejez y la senectud. La amistad. Madrid: Gredos, 2005.

DeYermond, Alan, Apollonius of Tyre: Two Fifteenth-Century Spanish Prose Romances. Historia de Apolonio and Confisyón del Amante: Apolonio de Tyro. Exeter Hispanic Texts, 6. Exeter: University of Exeter, 1973.

Macaulay, G. C., John Gower, The Complete Works of John Gower. Oxford: Clarendon Press, 1901. 3 vols.

Nicholson, Peter, An Annotaated Index to the Commentary on Gower's Confessio Amantis. Binghamton, NY: Medieval \& Renaissance Texts \& Studies, 1989.

OliveIRA, Maria do Carmo Correia de, «Sobre Muse e a Musa: (com)textos de sabedoria em Confessio Amantis de John Gower e sua tradução ibérica.» eHumanista 3 (2003): 1-18.

-, «Sobre as feras amansadas e outras incursões utópicas: uma leitura provisória do prólogo da Confessio Amantis de John Gower». En Animalia. Presença e representações. Eds. Miguel Alarcão, Luís Krus y Maria Adelaide Miranda. Lisboa: Colibri, 2002. 175-83.

-, «Gower e Castilho: Construtores da Memória». En Estudos de Traduçāo em Portugal. Ed. Teresa Seruya. Lisboa: Universidade Católica Editora, 2001a. 25-36.

-, «Idade Média: Traduções reais, reais traduções». En Histórias Literárias Comparadas. Colóquio Internacional. Eds. Teresa Seruya y Maria Lin Moniz. Lisboa: Edições Colibri, 2001b. 83-94. 
PIETSCH, Kart, «Zur Frage nach der portugiesischen Übersetzung von Gowers Confessio Amantis». En The Manly Anniversary Studies in Language and Literature. Chicago: UP, 1923. 323-27.

-, «Zum Text der Confision del amante por Joan Goer». Zeitschrift für romanische Philologie 46 (1926): 428-44.

Russell, P. E., «Robert Payn and Juan de Cuenca, translators of Gower`s Confessio Amantis». Medium, Aevum 30 (1961): 26-32.

—, Traducciones y traductores en la Península Ibérica (1400-1550). Bellaterra: Universidad Autónoma de Barcelona, 1985.

Santano Moreno, Bernardo. Estudio sobre 'Confessio Amantis' de John Gower y su versión castellana, 'Confisyón del Amante' de Juan de Cuenca. Cáceres: UP, 1990. 


\section{[CONFESSIO AMANTIS] ${ }^{15}$ \\ [1va] [LIVRO VIII] ${ }^{16}$}

[Capítulo 1] Depois que o Confessor Genius, ao rrequerimento do Amante, acabou de tractar da doctrina que Aristotilles enssynou a El-Rrey Alexandre cõ outros exẽplos, em este oitauo lyuro propos de fallar outra uez dAmor, segundo conpria a sua cõfissoõ, declarando en como ha hi mujtos que de uoontade seguem os começos da naturalleza, nõ sse rrefreando dos delleitos sobeios, segundo rrequere o aluydro da humanal rrazom e iposiçom da ley de Santa Igreia.

"O todopoderoso Deus, que de sy medes he sem começo e todallas cousas tẽ começadas aa ssua uõtade, assi como lhe aprouuge ẽcheo de toda gloria e prazer aquel çeeo en que El ssee entronyzado em sua seeda, preseruando pera sseu serujço çertos angos, que nom podem errar nem desuyar do sseu mandado. Mas el lançou Luçiffer fora daquel praziuel logar com toda a conpanhia apostetada daquelles que com elles sõ llyados, os quaees, danjos que dantes eram, som tornados em diaboos que cahirom no ynfferno, onde em treeuas e en pena de fogo pera ssẽpre ham de durar. Mas tanto que a corte deste Luçiffer foy cahida no logar hu mortal soberua a auya gujada, logo a Proujdençia daquel que todo pode fez Adam no Parayso ao sexto dia, e deulhe Eua por sua [1 $\mathrm{vb}$ ] conpanhya, dizendo a anbos que creçessẽ e multiplicassẽ por tal que da geeraçom dos homẽes o mundo dos ãjos, que eram perdidos, fosse rrecobrado pera encher aquel sancto logar que sobre a ssua graça staua entom uazio. Mas, segundo conta o Genesy, Adã e Eua pouco steuerom no Paraiso, e o porque notorio he quasi a toda humanal criatura, e en como Rraphael cõ sua spada queimante os lãçou anbos fora por tal que per trabalho de seus corpos guãçassẽ sua ujda aqui na terra. Diz Metodro em esta materia que lhe foy rreuellado per uysom en como Adam e Eua, ao tenpo que elles ueerõ a este mũdo, anbos erã uirgẽes e aujã en ssy mũ̃̃ grande uergonha, ataa que natureza os costrangeo damor e lhe [sic] enssynou a doctrina, primeiramente de beyjar e desy fazer o al que deuudo he a essa medes naturalleza. Per que ouuerom depois antre ssy filhos e filhas,

${ }^{15}$ Este trabajo pertenece a la edición de la Confessio Amantis portuguesa de Cortijo, que ha dormido - gracias enteramente a las labores del licenciadín Gervasete- por mucho tiempo (casi una década) el sueño de los justos (y hasta podría decirse que estaba «permanentemente adiada»). Por fin puede ir viendo la luz ahora (aquí en forma parcial), como lo hará el resto de la edición de la Confessio, proyecto al que ahora se une Maria do Carmo Correia de Oliveira. Nada, pues, en el retraso que imputársele a Cortijo. La edición que sigue prescinde, para esta publicación, de indicar y algunas informaciones pertinentes (aunque sí damos noticia de enmiendas dentro del mismo ms. y algunas modificaciones editoriales), que habrán, pues, de esperar a la edición completa de la Confessio, que - siempre que Gervasete no lo impida - no deberá hacerse de rogar. En este sentido, el libro VII al completo saldrá editado en breve en la Revista de Literatura Medieval. La puntuación aquí se moderniza en cuanto a uso de mayúsculas, etc., aunque se adopta un criterio bastante conservador en lo referente a uso de apóstropes, etc. El resto refleja la grafía del ms. tal cual. Añadidos editoriales van en corchetes cuadrados, texto a suprimir en corchete angular.

${ }^{16}$ Sigue siendo referencia obligada de consulta la anotación de Macaulay (III, 536-54) a su edición de las obras de Gower, así como Nicholson (493-569). 
dos quaees o primeiro ouue nome Cahym e o segundo foy Abel; duas filhas ouuerom outrossy, das quaees a primeira foy chamada Calmana e a segunda Delbora. E porque naquelle tenpo nõ era pecado o jrmãao nõ sse chegar aa jrmãa, Cahym tomou sua jrmãa Calmana e Abeel a outra, Delbora, pollos quaees a geeraçom deste mũdo primeiramente foy multiplicada. Dizsse, por enxenplo, [2ra] en como neçessidade nom ha lley. E esto se prouou mũỹ bem naquelle tenpo e durou assi ataa segunda ydade, que todo o mũdo por pecado no Delluuyo de Noe foy destroido, en tanto que nom ficarõ mais de oyto pessoas em saluo. Entõ o lynhagem humanal staua mũỹ abaixado, ca de Ssẽ, Cam e Japhet, que eram os filhos de Noe, todallas nac[,] õoes dos homẽes outra uez forom rrenouadas, en tanto que, segundo contam os liuros da geeraçom, destes tres beerom depois seteenta e çinquo naçõoes, pollas quaees todo o mũdo ẽ logares departidos foy poboado. Mais, assi como natura os põgia, assy faziam elles entõ, nõ doujdãdo o jrmãao de tomar a jrmãa por sua molher ${ }^{17}$, ataa o tenpo dAbrahão, en que começou a terçeyra ydada [sic]. E, porque o mũdo era ia abastado de gentes, foy defeso o casamento antre os jrmãaos. E era mãdado que os primos casassẽ com as primas, ca Abrahão, ante que moresse, chamou seu serujdor e disselhe em esta guisa: «Por cobyça de bẽes mũdanaaes nõ casaras meu filho Jsaac cõ algũa molher, mas cata o sseu casamento com algũa chegada ao sangue, donde el deçende». Por a qual cousa o serujdor, tanto que el foy morto, leuou este [2rb] seu filho a casa de Bacuel e casouho cõ Rrabeca, sua filha, porque achou que era sua parenta mũỹ chegada. Per esta guisa, polla enssynãça de Abrahão, depois que Jsaac foy morto Jacob ${ }^{18}$, seu filho tomou por molheres duas filhas de Labom, seu tyo. E da primeira, que auya nome Lya, ouue seis filhos; e da outra, que era chamada Rrachel, ouue dous. E aallem desto aynda ouue quatro filhos aa de fora, dos quaes os dous eram de Balla e os outros dous de Zelpha. Estes doze filhos polla proujdençia de Deus som chamados os doze patriarchas, de que proçederõ depois os doze tribus de Ysrrael, que entom forom ditos Ebreos, os quaees geeralmente ataa bynda de Christo guardarom senpre esta liança de parentesco mais que outra gente. Mais aquel costume foy depois deffeso antre nos, que ssomos baptizados, ca o Papa, em dereito canonyco, manda que nehũu nom case cõ sua parenta aaquẽ do quarto graao. Mas, nõ enbargando que a Santa Egreia deffenda taaes casamentos, assaz hi ha ao tenpo dagora que com braueza damor hu quer que o acham tomã o que podem, porque Amor, segundo dizem as gentes com doudiçe, do delleytamento que deseia, aas uezes he afastado de todo boo siso [2va], ẽ tanto que nõ guarda parentesco nẽ rrelligiom tã pouco como faz o gallo antre as gallinhas ou o granhõ antre as egoas.

Filho meu, ssey çerto que de tal delleytamento he mujto de culpar aquel que o husa, e, porẽ, se tu em algũu tenpo cahiste em caso semelhauel, nõ aias rreçeo de o descobrir ẽ tua confissom».

Amante: «Padre meu, Deus sabe que eu nũca em amor fuy tã desassisado que as mjnhas parẽtas ouuesse damar so aquella tẽçom, nẽ ssej maginar a que fym eu auya dendoudeçer por nehũa freira, porque, aynda que o seu amor

\footnotetext{
17 'molher': 'jrmãa molher', 'jrmãa' tachado.

18 'Jacob': 'per Jacob', 'per' tachado.
} 
ouuesse guaançado, bem sey que me nom bynria por ello onrra nẽ proueito. Porem, padre meu, pareçeme que he bem de me pergũtardes por as cousas desuairadas, mas, por uos dizer toda a uerdade, chaamente digouos que de todallas molheres do mũdo eu soo solto e lyure, senõ dhũa ssoo que o meu coraçõ tem uençido e preso».

Confessor: «Ora ueio mũỹ bem, filho meu, que a tua pallaura senpre sta ẽ hũu lugar. Mas enpero dhũa cousa tees mũỹ grãde graça, pois podes scusarte do amor que ante disse que mujtos homẽes husam, o qual he semelhante a agrodoçe, porque, aynda que o homẽ em gostando senta dulçura aa primeira, [2vb] depois achallo ha mais azedo que o bynagre, ou bem como o bocado que he mesturado com a peçonha. Assy que aquel que en tal amor enprega seus delleytos achara ẽ fym que quãto ffez he perdimento de tenpo, segundo per mujtos e desuayrados enxenplos contheudos em scriptura se mostra claramente».

[Capítulo 2] Aqui falla contra aquelles que Venus cõ ardor de maao deseio tem açesos, en tãto que por conprir seus delleytos nõ sse guardam de chegar a ssuas jrmãas proprias. E conta enxenplo dalgũ a que esto aconteçeo.

«[P]rimeiramente eu acho en como Gayus Calligulla, seendo enperador de Rroma, foy muyto de culpar em este pecado. Ca el, per força, tres suas jrmãas ouue de uirgỹdade. E des hi, como homẽ que en todo era maao billãao, mandouas degradar todas tres fora da terra. Mais depois, a cabo de pouco, Deus, com sua yra, lhe tolheu o emperio e a ujda, en tal guisa que por a delleitação dhũu pequeno tenpo os seus delleitos deste mũdo e do outro pera ssenpre forom perdidos.

Desta doudiçe eu acho aynda mais en como Amõ, contra rrazõ natural, ouue jũtamento com Thamar, que era sua jrmãa. Mas el conprou depois mũỹ caramente aquella delleytaçõ, quãdo Abssollõ, seu jrmãao, polla desonrra feita a [3ra] Thamar, que era outrossy sua jrmãa, por byngança desse pecado o matou cõ suas mãaos».

[Capítulo 3] Aqui conta en como Loth per conssẽtimento e aazo de duas suas filhas geerou ê ellas Moab e Amö ${ }^{19}$.

«[A]ynda por mayor eujdẽçia desta cousa, hũa speriençia uerdadeira he achada na Briuya, en como Loth, depois que sua molher foy tornada em statua de sal, enprenhou dua [sic] suas filhas que ouuera della. E tanto que chegarõ ao tenpo de sseu parto parirom senhos filhos, Moab e Amõ, dos quaees proçederõ depois duas naçõoes ${ }^{20}$. Mas por quãto as rrayzes nom eram boas, sem rrazom nõ foy aynda que os rramos fossẽ maaos, porque da falssura dos moabitos e do poderio dos amonytos, que do sseu começo eram mal geerados, o poboo de Deus em Jsrraell e Judea, segundo conta a Briuya, steue mujtas uezes em grandes agrauos e tribullaçõoes.

E esto que me ouuyste dizer que aconteçeo a outros muytos a ty pode seer mũ̃y boa doctrina, filho meu. Conuẽ que aquel que toma delleytaçom ẽ logar de-

19 'e Amõ' fuera del margen de la caja de escritura.

20 'naçõoes': 'g naçõoes', 'g' tachada. 
feso na lley, conuẽ que ao depois se aia darreprender mũỹ grauemente. E porque do scarmento dhũus vẽ a doctrina aos outros, os homẽes ao tenpo dagora com rrazõ deuẽ [3rb] tomar enfformaço do tenpo pasado pera leixarẽ o mal e husarẽ senpre do bem. Mas pera trager aa memoria en como todo homẽ deuya squiuar ${ }^{21}$ de nom husar de delleytamento carnal e de o nom fazer spiçialmente onde ha parentesco, pollo passado o pode entender, porque a mayor parte rreçebem por ello byngança, de que o proçesso dhũa storia que he mũỹ longa douuyr por tua rrene[ ] brança te cujdo ora de contar».

\section{[HISTÓRIA D'APOLÓNIO]}

[Capítulo IV] Aqui falla daquelles que em amor contra rrazõ natural husam de sseus delleytos e conta hüu enxenplo que aconteçeo ãtre o gräde rrey Antiocho e sua filha, da qual el, depois da morte de sua molher, priuou a uirgỹdade per fforça.

[C]ontasse em hũa cronjca antiga que he chamada Pãtheó en como o grande Antiocho, de que Antiochia originalmente leuou seu nome, foy casado com hũa nobre Rraynha da qual ouue hũa filha. Mas tal fortuna se açertou cõ de cabo, que a ujda desta onrrada rraynha lhe foy tirada. Por a qual cousa El-Rrey, achandosse soo sem conpanheira, tomou en ssy mũy grande noio, como aquel que outra molher nõ tynha ẽ sua casa que de conta fosse, senom sua filha, que em fermosura ẽtom era sem parelha. Mas ${ }^{22}$ o homẽ, [3va] quãdo he biçoso e byue aa sua uõtade, por a franqueza da ssua carne muytas uezes caae en pecado. E esto sẽtyo a cabo de pouco aquella uirgem sua filha, que per mandado de sseu padre byuja dentro em sua camara. Porque cobyça de conprir maao deseio, nõ sguardando conçiençia, çegou seu padre com delleytamentos, en tãto que el con toda sua entençom ordenou maneira en como ella pera ssenpre fosse perdida.

Cada dia auẽdo el uagar a ssua uontade como el queria, quãdo hũu dia byo tenpo pera ello lançou mãao desta sua filha. E ella, como moça chea de temor, nõ sse soube defẽder delle que per fforça lhe nõ priuasse sua uirgỹdade. Assy que por mujto que ella entõ chorasse pouco lhe prestou. Ca as molheres que lhe eram dadas por suas guardadeiras, como sua ỹffortuna quis, por aquella ora todas stauã fora da camara. Per esta guisa aquella uirgem per aazo de sseu padre, que ouue sabor destragar sua propria came, soube primeiramente que cousa era gostar homẽ. Mas depois que esta obra, que segundo rrazõ he mũỹ auorreciuel e contra naturalleza, foy acabada, El-Rrey seu padre sahio fora da camara e ella ficou dentro [3vb] cõm mũỹ grande noio e medo que ouue da byngança que poderia bỹr do grande pecado que era feito.

21 'squiuar': 'scusar squiuar', 'scusar' tachado.

22 Se lee perceptiblemente una línea por encima de esta que parece responder a texto guillotinado, aunque no hay corte entre el folio precedente y el comienzo de este (de acuerdo al texto español). 
Ora assy foy que a primeira que entom entrou onde ella staua foy hũa sua ama que a criara de pequena, a qual lhe pergũtou por que era assy triste e de tam noioso senbrante. Mas ella, seendo en ssy mũỹ noiosa por cousa que nom podia seer bjngada, cõ uergonha nõ soube que rresponder a sua ama, saluo que a cabo de pouco chorando fortemente demãdoulhe perdom ẽ esta guisa. «Ay de mỹ, jrmãa, por que eu em este mũdo fuj naçida, pois aquel que me geerou me ha rroubada de toda mjnha onrra?». E cõ esso per uezes cahyu smoreçida chamando sẽpre polla morte, ataa que o spiritu da ujda staua en ponto de lhe sahir fora do corpo. A outra, scujtando o que ella dizia, por a confortar rrespõdeo dizendo. «Filha, pera toruar o maao deseio de uosso padre cousa he que nom pode sseer ajnda que queiraaes. $E$ pois que o feito he feito, nõ ha hi cobro, ca assy sofrem aquellas que mais nõ podem». Assy que ElRrey dhi en diante tanto continohou com ella seus delleitos, que pollo grande sabor e delleitaçõ que em ello [4ra] auya çegoulhe o entendimento, de tal guisa que em fym o que fazia nom o auya por pecado; ella da ssua parte nõ lho ousaua contradizer.

A Fama, que per desuairados camjnhos bay a todollos rregnos, fez saber em outras partes a fermosura e alta linhagẽ desta uirgem, assy que por amor de casar cõ ella beerom mujtos e mũỹ onrrados príncipes. $E$ outros ẽuyarõ dizer a seu padre, como aquelles que nom entendiã saluo toda onrra, que queriam casar cõ ella. El-Rrey, quãdo bio que todos deseiauã de casar cõ sua fillha, andou conpassando dentro ẽ sseu entendimento en como sem sua desonrra podesse toruar o casamento. E em fym pos por lley que qualquer que sua filha quisesse demãdar, se el nõ declarase a uerdade dhũa questom de cousas çertas que el per ssua boca lhe pergũtaria, fosse çerto de perder logo a cabeça. Por a qual cousa as cabeças de mũỹ mujtos que por ello morrerõ, suas cabeças stauã postas sobre lanças em dereito da porta dos paaços dEl-Rrej, ataa que per tenpo os outros que eram sesudos por mjjgua da rreposta rreceauã de fazer a proua.

\section{[Capítulo V] Da vynda dEl-Rrey Apollyno de Thiro em Antiochia.}

[A]ssy aconteçeo que o nobre prinçipe Apollino de Tyro, como ca[4rb]ualleiro nouo e namorado e talãtoso e mũỹ esfforçado, penssando nas nouas que ouuyra dizer do feito dEl-Rrey dAntiochia, propos em seu coraçom de sse poer ẽ auentura por prouar a ssotilleza daquella questom se a adeujnharia. E, teendo prestes o que auya mester pera sua ida, cõ peça de gentes onrradas entrou no mar e syngrou seu camjnho ataa que no porto dÂtiochia arribou ẽ saluo.

Este nobre caualleiro Appollyno de todallas sçiençias naturaaes e outras sotillezas sabia assaz. E cõ esso as pallauras que fallaua tã graçiosamente eram ditas, que os que o escuytauã nũca sse enfadauam de o ouuyr rrazoar. Tanto que el cõ todollos seus foy sahido en terra, logo sse adrençou dereito aos paaços onde El-Rrey staua e, depois que chegou aa sua presença, quãdo byo tenpo ẽmentoulhe a materia do casamento de sua filha. Mas El-Rrey lhe rrespõdeo dizendo en como primeiramente lhe auja de dar absolluçõ a hũa questom que lhe el diria, da qual fosse çerto que se el errasse nõ scaparia de perder a cabeça. Apollyno lhe pergũtou entom polla questom queianda era. El-Rrey cõ o olhar spantoso e cara rrebusta declarandolhe o caso disse em esta maneira. 
«E $\mathrm{u}^{23} \mathrm{com}$ trayçom som soportado [4va] comendo a carne de mjnha madre, cujo marido meu padre eu cuydo de buscar, o qual outrossy he filho de mjnha molher. Quem a esta mjnha questom souber dar abssolluçõ uerdadeira liuremente auera mjnha filha sem duujda nehũa. E sse el da sua rreposta falleçer, seia çerto de perder a uyda sem outra alçada». «Porem filho meu», disse El-Rrey, «sey bem aujsado sobre esta cousa, pois tua uyda por ello ha destar em ballança».

\section{Ãtiocho. \\ [Capítulo VI] Reposta dApollyno aa questom proposta da parte dEl-Rrey}

Depois que Apollyno ouue rrepetidos os pontos della, rrespondeo em esta guisa: «Se tu quiseres que eu descobra a uerdade desta tua questom, digote que he hũa cousa de segredo dantre tua filha e ty e sta sobre uos anbos soomente». El-Rrey entom ouue en ssy mũỹ grande pesar, penssando, se elle descobrisse a cousa queianda era, que pera ssẽpre seria auergonhado. E por ende cõ pallauras sotys que andaua magynando disse:

«Filho meu, posto que tu por agora seias de pouco saber, nõ he de maraujlhar, porque aynda nom es chegado aa tua conprida ydade; mas daqui en diante para bẽ mentes que nom tenhas em pouco tua uyda que sta em aventura [4vb]; e pera sobresto seeres mjlhor auysado eu de mjnha graça te quero outorgar triynta dias despaço».

Com leçença e tenpo asynado partiosse este prinçipe nouo e foysse seu camjnho, entendendo mũỹ bem dentro em seu coraçom —e per enfformaçõ que ouue doutras pessoas - que El-Rrey lhe dera aquelle spaço por tal de o spãtar e auer del medo. E por ende, temendosse da trayçom porque disera a uerdade, subitamente de noite sem mais tardança entrou na sua barcha e foysse pera Tyro, õde andou ymaginando o perigoo que lhe poderia bỹr se el descobrysse $o$ feito dantre El-Rrey e sua filha; por [sic] sabia de çerto que o coraçom delle era tal que per algũu alleyue e traiçom nom leixaria de o perssegujr por ello ataa morte. E por ende, por saluar sua ujda, propos em sua uoontade de leixar sua terra por hũu tenpo. E de noite, nõ sabendo nehũu parte, meteusse no mar ẽ nauyos carregados de triygo. E tãto que os marinheiros $\mathrm{o}^{24}$ sentirõ dẽtro, gujdarõ os treus e fforõ sua bia.

Mas fallando do cujdado que ouuerõ os de Tyro, quãdo sentirõ que o seu senhor era ydo, pyedade he de o saber, como aquelles que perderõ [5ra] contenẽça e tallante, fazendo geeralmente antre ssy tal peendença que leixarõ o cantar e dançar e todollos outros sabores en tanto que o prazer e allegria que sohiam husar todo entom foy tornado ẽ sseu contrario. Assi que pollo noio que cada hũu en ssy tomou do que era aconteçido todos se uestirõ de doo e leixarõ de fazer as baruas e cortar o cabello, os banhos e stufas per toda a billa forom çarrados, ca nom auya hi criatura que sabor ouuesse de jogar nem de tomar prazer, mas ante chorauõ todos por ele mũỹ dooridamente dizendo. «Ay senhor! Que sera de

\footnotetext{
${ }^{23}$ Al margen izquierdo: 'questom'.

24 'o' sobrescrito entre 'marinheiros' y 'sentirõ".
} 
nos?, pois nosso prinçipe e rregedor per quem stauamos mãthudos em nossa onrra sẽ prazimento de toda a comunydade tã subitamente he assy partido».

Mas agora tornemos a fallar da nossa storia que ante começamos a contar.

\section{[Capítulo VII] De como mãdauã dar peçonha a Apolyno ${ }^{25}$.}

$\mathrm{O}$ poderoso rrey Antioco, seendo ẽ ssy mũỹ sanhudo por a rreposta deste prinçipe de Tyro, consselhousse cõ hũu caualleiro mũỹ treedor en todas suas obras, o qual era chamado Tallyarto. E deulhe peçonha conposta dentro ẽ hũa buçeta e douro hũa grãde soma, mandandolhe que logo a pressa se fosse dereito a Tiro e que nõ leixase [5rb] por custa algũa de matar o prinçipe Apollyno se podesse.

Tanto que este maao caualeiro entendeo a uõtade dEl-Rrey queianda era, meteuse logo em hũu gallee e com uento mũy boo de biagem foisse sua bya ataa que se lhe açertou darribar ẽ o rrio de Tyro, onde el sahyu en terra e se foy ao burgo tomar pousada por hũu tenpo. $\mathrm{Ma}$ [s] por tal de nõ seer conheçido das gentes que hi morarauõ, mandou ${ }^{26}$ os uestidos e foise andar pollas rruas, onde el achou as gentes fazer seu planto mũỹ dooridamente. Pergũtoulhes entõ qual era a rrazom por que faziam tamanho doo, e elles lhe diserom todo o caso: en como seu senhor, sem fazendoo saber a nehũu delles, se fora fora da terra e nom sabyã pera onde. E, quãdo el soube de çerto que aquello era uerdade e que ueera hi trabalhar em uãao, tornousse logo a Antiochia e contou a El-Rrey todo o que bira e ouuyra da fogida de [A]pollyno. El-Rey por hũu tenpo ouue en ssy por ello mũỹ gram pesar, mas quãdo byo que a ssua sotilleza nõ prestou pera acabar o que queria dhi en diante abrãdou sua yra e nom fez dello conta.

\section{[Capítulo VIII] Como Apollyno chegou aa çidade de Tarsya.}

Mas aallem desto, pera tu saberes [5va] as auenturas que ouue este prinçipe de Tyro de que eu começey de fallar, assy foy que el gujou seu cursso dereito pera Tarssia, e alli arribou en terra. $\mathrm{Na}$ qual çidade moraua entom hũu rrico burges per nome chamado Estrangullyo, e sua molher Dionysya ouue nome, segundo conta o llyuro, em cuja casa este prinçipe em quãto hi steue aprouue de sseer apousẽtado.

Ora assy foy que tenpo auja que os moradores daquella çidade por mjgua de pam padeçiam grande fame, en tanto que todos geeralmente stauã em ponto de sse perderem. Mas Appolyno logo, como ouue notiçia de ssua grãde lazeira, de sua propria uõotade e liberal coraçõ fez bỹr en terra o triygo que tragia nas suas naaos e mãdouho entregar aa çidade, sem rreçebendo por el preço algũu. Mas des que o mũdo primeiramente foy começado nũca foi feito a homẽ naçido tanto prazer como os ${ }^{27}$ moradores dhi fezerõ entõ a el.

Ca elles por sua rrenẽbranca ordenarõ sseer feita hũa figura de latom dourada semelhante a el ẽ todo, a qual foy asseentada ẽ meo da geeral praça, por tal

25 'Apolyno' escrito en el margen derecho fuera de la caja.

${ }^{26}$ El texto castellano indica que el original debió posiblemente decir 'mudou os'.

27 'os': 'a os', 'a' tachada. 
que em uẽedo o sseu rrostro a memoria do bem que per el biera pera ssenpre ficasse nos coraçõoes dos homẽes. Andando hũu [5vb] dia este senhor com outras gentes fora da çidade por sse sollaçar, hũu burges de Tyro, per nome chamado Helcano, se pos en giolhos antel dizendo: «Senhor, por Deus eu uos peço que sobre todallas outras cousas parees mentes a uos medes e uos guardees do grande e poderoso Rrey Antiocho, que anda conpassãdo uossa morte quãto pode». Apollino gradeçeulhe mujto o sseu boo perçebimento, mandandolhe calladamente que quãdo chegasse a Tyro nõ contrase [ $\mathrm{sic}]$ por nouas que o byra em Tarssea.

[Capítulo IX] Aqui diz en como Apollyno se partio de Tarssia e depois cõ tenpestade se ouuera de perder no mar; e de como outrossy scapou e foy láçado en terra пии.

[F]ortuna senpre he mudauel e nõ pode star queda aynda que queira; ca ora he alta ora he baixa, ora sta dereita ora jaz derribada, ora he chea de prazer outra ora he chea de noio, assy como polla storia adiante claramente te sera demostrado. Este senhor nouo, por cujdar o que the seria mjlhor de fazer em este caso, dentro en ssy ouue pouco assesego. E fynalmente propos de sse mudar daquel lugar e bjr buscar mais longe algũa outra ter[r]a stranha en que steuesse por hũu tenpo.

Spedyosse entom dos de Tarssea e meteosse em seu naujo [6ra] e tomou seu cursso dereito ao mar, onde Ffortuna quis obrar de sua ley e mostrar en como a ${ }^{28}$ este rrey nouo queria seer contraira. $\mathrm{E}$ a cabo de pouco leuãtousse hũu uento mũỹ forte e o tenpo começou descureçer e a tormenta creçer, tam fora de rrazom que com caabres nem ancoras - - por fortes que fossem- nõ aujam poder de rreteer o nauyo en porto que per aazo de tenpestade se nõ quebrantasse. Os marinheiros, cõ medo que aujam, nõ sabiam dar rremedio ẽ como saluassẽ suas ujdas, mas stauam oolhando quãdo a augua do mar os sorueria.

Entom auya antre elles grande tristeza e chorar assaz; ca El-Rrey, em ueendo o naujo que staua pera sse perder, aynda que the pouco prestasse, ouue en ssy mũỹ grande coita, porque logo em hũu ponto o masto rrebentou e o treu en pedaços todo se rronpeo. O naujo sem gouernalho pera onde as uagas o queriam leuar andaua gujado, ataa que ouuerom bista de terra. Entõ nõ auja hi pequeno nem grande que por se saluar nõ fizesse uoto pera rromagẽ algũa. Pero, nõ enbargando todo o que assy fezerom nem arte de marear que os marinheiros soubessem, Neytimus cõ elles nõ queria auer piedade; mas ante, como aquel que do mar he prinçipal [6rb] senhor, deu com o nauyo em hũu penedo e fezeo en pedaços ante que aa terra podesse chegar.

Mas aquel que todallas cousas tem ẽ sua guarda prouue auer com este rrey misericordia e conpaxom. En tal guisa que ençima dhũa tauoa o leuou a terra ẽ saluo, leixando perder todo o al, de que elle en ssy ouue mũỹ grãde pesar. Assi que este senhor nouo scapou entõ dhũa mũỹ forte auentura e ẽ pobre stado, teendo o collor de seu rrostro de boo pareçer foy tornado amarello e mũy botado per aazo da auga do mar en que jouuera. E cõ esso o frio era tam grãde ẽ elle,

28 'a' sobrescrito entre 'como' y 'este'. 
que nom sabia en como aa ssua grande pena podesse auer rremedio. E esso meesmo quãto das rriquezas que conssigo trouxera bem entẽdia que pera as cobrar ẽ uãao poeria ẽ ello trabalho.

Mas aquella Fortuna que o entõ guardou de morte ẽ sua mayor desasperaçom subitamente lhe enujou depois acorro. Ca hũu pescador que bynha pollo camjnho parou mentes e bio hũu homẽ star nuu no ylheeo, e des que soube a uerdade da cousa quejenda era, auendo del mũỹ gram doo, deulhe parte dos uestidos que tragia, que eram assaz pobres. A qual cousa lhe El-Rrey gradeçeo mujto, dizendo que, sse Deus em algũu tenpo [6va] o quisesse tornar a ssua onrra, que aquello que the auja feito lhe seria mũỹ bẽ congallardoado. E entõ lhe fez pergũta se ssabia parte dalgũa ujlla hi açerca. E o pescador lhe resspondeo que bem perto dalli acharia hũa çidade chamada Pentapully, õde moraua hũu Rrey e hũa Rraynha sua molher. Quãdo Apollyno aquello ouuyo começou hũu pouco de sse allegrar, rrogando ao pescador que lhe enssynase o camjnho pera alla, e elle assy o fez. E des hi spidiosse dEl-Rrey e foisse pera onde lhe conpria, rrogando mũỹ deuotamente a Deus que o seu grande noio lhe quisesse tornar em prazer $\mathrm{e}$ em allegria.

[Capítulo X] Aqui conta en como Apollyno, tãto que chegou aa çidade de Pentapolym, ouuyo apregoar hüu jogo, do qual por el sseer uençedor aa ora da çea foy bem rreçebido dEl-Rrey Athestes ${ }^{29}$.

[C]hegou o prinçipe Apollyno aa çidade de Pentapollym ante de ora de noa. E depois que ouue comjdo aquello que pode achar foy andar polla çidade por ueer queianda era. E chegando a hũu logar onde achou de gente noua grande conpanha foilhe dito como naquel dia se auja de fazer hũu jogo, segundo costume da terra, ao qual todos aquelles que erã ligeiros e de boa força [6vb] auyã de bỹr prouar sua força e ualẽtia. Mas a usança daquel jogo era tal, que todo aquell que em quisesse prouar ligeiriçe ou força se desuestisse nuu, como o jogo demãdaua; e ajnda mais, de qualquer stado e condiçom que o homẽ fosse de jogar ẽ el nõ lhe auja de sseer negado. Em hũu canpo largo e fermoso, presente ElRrey Artestrathes, foy jogado este jogo, no qual a frol dos mais tallantosos da çidade e da corte se andarõ prouãdo, porque assy era ordenado, e aquel que entõ mjlhor prouasse auja dauer cousa çerta por gallardom, e esso meesmo na çidade pera ssenpre grande louuor.

Apollyno, que en todalas cousas era mũỹ deestro, entrou no jogo cõ os outros, onde guãçou tal nomeada que El-Rrej por sua boca disse en presença de todos que el sobre quãtos hi stauõ leuaua grande melhoria. E por ende depois, quãdo El-Rrej ouue de çear, mãdouho chamar. E el soo, ssẽ bỹdo com elle nẽgũu, chegou logo a sseu mãdado. Mas enpero ajnda que entom beesse soo se bem uestido fora nõ ouuera a el semelhãte de corpo nẽ de geesto. El-Rrey, cobyçando de o afemençar aa sua uoontade, mãdou ao seu ueedor [7ra] da salla que o fezesse asseentar en tal lugar que elle e a Rraynha sua molher o podessem bem ueer ${ }^{30}$ sem enbargo.

\footnotetext{
29 'Athestes' escrito fuera del margen, a la derecha de la caja.
}

30 'ueer': 'ouuyr ueer', 'ouuyr' tachado. 
O ueedor, por conprir o mãdado de sseu senhor, parãdo outrossy mentes aa onrra que ãte auja merçido, fezeo asseentar ẽ cabeçeira de mesa, da meatade a qual staua en dereito onde El-Rrey e sua molher syam assẽetados. Apollyno parou mentes arredor de ssy e byo mujtos senhores seer cada hũu em seu stado. E, nẽbrãdosse do tenpo que perdera, tal noio xe [sic] lhe chegou ao coraçom que steue quedo, como homẽ que por cuydar no que lhe aconteçera nõ auja sabor de comer.

[Capítulo XI] Aqui diz en como Apollyno, seendo aa mesa, nó comeo cousa algüa.

[E]1-rrey Artestrathes, parando mentes ao cujdoso senbrãto que el demostraua, de sua gentilleza mãdou a hũa sua filha, que aa sua mesa per ante el staua en pee, segundo entõ era husança, que sse fosse pera elle e lhe fezesse todo prazer que podesse. A qual, por conprir o mãdado de sseu padre, foisse dereito õde el sya asseentado e pergũtoulhe quem era e donde beera, rrogãdo mũỹ aficadamente que leixasse aquelles seus penssamentos tã pesados. «Senhora», disse elle», «meu dereito nome he [7rb] chamado Apollyno, e das mjnhas rriquezas - se a uos prouuer de o saber - assy he que em byndo pera aca eu as perdy todas no mar. A terra en que eu naçy e onde stam as mjnhas rrendas e bẽes de rraiz eu os leixey encomendados a Deus no rregno de Tyro quãdo me della party». E departyndo anbos sobre esta rrazõ as lagrimas dos olhos lhe bynham correndo pollas queixadas a fũdo.

Quãdo o El-Rrey byo assy chorar dentro en sseu coraçom ouue del mũ̃y grã doo e mando outra uez por sua filha, dizendolhe que fizesse logo bỹr a ssua arpa, por tal que en tangendo cõ ella o coraçom deste noioso homẽ podesse rreçeber en ssy algũ prazer e alegria. A filha pos logo em obra o que lhe seu padre mãdou e assẽetousse em hũa cadeira jũto com elle, começando de tanger e cãtar por lhe fazer todo desporto que podia. Mas el porem nõ leixou de sospirar mujto ameude. E ela pergũtoulhe como lhe pareçia o seu tanger. "Çertas, senhora, mũỹ bem», disse elle, «pero se uos en tanger guardassedes mesura -queianda uos eu enssynarey, se a uos prouuer-, creeo que uos prazera de a ouujrdes». Entõ lhe rrogou ella mũỹ aficadamente que tomasse a arpa e lhe mostrasse [7va] aquella mesura de que ell fallaua. E esso meesmo El-Rrey e a Rraynha cõ os outros senhores $^{31}$ todos que hi stauam, todos lhe rrogauã que lhes mostrasse algũu prazer se o ssabya. Tomou el entom a arpa e tẽperouha aa ssua guisa, e em tangendo com ella começou de cantar tam graçiosamente que a quãtos o ouuyrom, a todos apareçeo que era uoz dangeo que lhes soaua nas orelhas. E espiçialmente a filha do Rrey, a quem sua melodia mais prazia que a nenhũu dos outros, como aquella que en penssando na rreposta que lhe el dera no começo ẽcendeo dentro no sseu coraçom que nõ podia seer que de gentill sangue nõ ueesse, porque as obras cõ a ssabedoria da sua enssynança dauam dello testemunho.

Depois que ouue acabado seu tanger, que fezera por segujr a uõntade, alleuãtarõ logo as mesas e cada hũu se foy pera onde lhe conpria. El-Rrey mãdou chamar seu camareiro e disselhe que buscasse hũa camara açerca da ssua en que

31 'senhores' escrito en el margen fuera de la caja (a la derecha). 
este Apollyno que a el por entom era strangeiro ouuesse do dormyr. O qual sem mais tardança por conprir seu mãdado poseo logo em obra.

[Capítulo XII] En como Apollyno ficou cō El-Rrey pera enssynar sua [filha] $e$ en como o ella outrossy fez uestyr de panos onrrados.

[A]pollyno spidyusse entõ dEl-Rrej e da Rraynha e de sua filha, a qual pidio de merçee a sseu padre que lhe desse logar pera aprender daquele [7vb] homẽ nouo a doctrina daquella sciençia que elle sabya. A qual cousa El-Rrey da sua parte logo outorgou cõ tanto que a el prouuesse de o fazer ${ }^{32}$. Assy que acordado foy antre elles ante que dhi partisse que Apollino auya de fazer sua dilligençia por enssynar esta uirgem fremosa darte de musica que ella saber mujto deseiaua. Esto assy feito, spidirõsse todos por aquella noite. E em outro dia polla menhã esta onrrada senhora enujou ao homẽ de Tiro mujtos uestidos e outros boos apostamentos com auõdança douro e de prata pera sua despesa. $E$ el de sua parte dhi en diante fez quanto podia pera a serujr mũỹ bem aa sua uoontade, ataa que ella foy enssinada do tanger da arpa, de çitolla e de rrota com outros pontos e toaçõoes desuayrados de musyca e de mesura. Mas assi como cada dia ueemos a olho en como moçidade en ssy he mũy fraca, esta uirgem per aazo de uagar continoado $<f e z>$ cahio em hũu tal caso que amor contra sua fresca e fraca moçidade fez hũa querella en tal guisa, que aynda que nom quisesse conuynhalhe per fforça dobedeçer aa ssua ley, no qual amor ella padeçeo mujto mayor pena porque ãte daquella ${ }^{33}$ ora nũca sentyra que cousa era. $E$ antre os padiçimentos que auya asy foy que por amor deste homẽ de Tyro o sseu coraçom aas uezes era quente [8ra] como fogo e outras uezes era frio como a neue; e esso meesmo, segundo a condiçom da ssua ymaginaçom, ora se tornaua coorada e outra ora se lhe demudaua toda sua coor. Mas, nom enbargando os penssamentos desuairados que lhe bynham pollo cujdado, cõ temor de uergonha feminyna senpre guardou mũỹ bem sua nomeada. Pero a cabo de tenpo o sseu amor staua en tal ponto, que ella perdeu o apetito do comer, do beuer e do dormyr. Como aquella que nom sabia outro consselho, se nom por tal dauer logar de cuydar aa ssua uoontade, muytas uezes ficou dentro na sua camara e nom sahio della fora. Por a qual cousa El-Rrey seu padre nom sabendo parte da causa da sua ynfirmydade staua ẽ grande duuyda da ssua uyda.

[Capítulo XIII] En como tres filhos de dyuerssos prinçipes demandarom a filha dEl-Rrey pera casamento e de como ella nó curando dos outros soomente scolheu Apollyno por marido.

[O]ra assy aconteçeo hũu dia que, em hyndo El-Rrey por se desportar fora da çidade, os filhos de tres prinçipes onrrados se poserom ẽ giolhos ante el pidindolhe cada hũu em seu cabo que lhe desse conssẽtimento de casar com sua filha. El-Rrey, querendo guardar a onrra della, disselhes que por quãto jazia doẽte e nom sahia fora de sua camara [8rb] que nom era entom tenpo de fallar sobrello aa ssua pessoa della. Mas mãdou que cada hũu aa sua uoontade fezesse

32 'fazer': 'saber fazer', 'saber' tachado.

33 'daquella', 'da' escrito en el margen izquierdo y fuera de la caja de escritura. 
hũa enformaçom, na qual ffezesse mençõ de sseu nome e do de sseu padre e dos bẽes que auya. E tanto que as ella ouuesse bistas fossem çertos que cada hũu auerya sua rreposta, cõ o qual consselho todos tres ficarom mũỹ ledos. E cada hũu screueo de sseu cabo assi como per El-Rrey foy mandado. E desy entregaronlhe suas enfformaçõoes, as quaees elle logo enuyou a ssua filha, rrogandolhe que de como achasse em seu coraçom que logo per sua mãao lhe screuesse a rreposta. A filha dEl-Rrey, ueendo as enfformaçõoes todas tres e nõ curando do amor de nehũu delles, penssou que entom era tenpo de sse poer na guisa de sseu padre e na carta da rreposta que lhe sobrello ẽuyou disse em esta guisa:

«A uergonha que as uirgẽes ham nom a ousam aas uezes descobrir per pallauras; porem, padre senhor, per esta carta faço saber aa uossa merçee que sse eu Apollyno nõ ouuer por marido, de todollos outros que no mũdo som nõ farey conta. E digo aynda mais, que, falleçendo de o nom teer por meu marido, seede çerto que uos per mỹ ficarees sem filha».

Esta carta apresentada ante El-Rrey, aquelles que bynham demandar sua filha [8va] assaz se apressauã por auer a rreposta queianda era. E tanto que ElRrey entendeo a postumeira uoontade della, a cada hũu delles deu sua rresposta apartadamente, en tal guisa que nehũu delles sabia a puridade do outro. Partironsse ẽtom dhj e encamynharõ pera onde queriam. Mas El-Rrey com trigança nom era tanto uençido que el por ẽtom a puridade de sua filha quisesse descobrir a njguẽ ${ }^{34}$. Mas sofreo todo dentro en ssy, ataa hũu tenpo que chamou pera ssua camara este homẽ de Tyro e mostroulhe a carta da puridade que lhe sua filha enujara, o quall, poendosse em giolhos, mũy homjldosamente a elle $e$ a ella rrendeu mũy grandes graças. Entom, ante que eles da camara partirem pera ffora, em rrazom do casamento anbos de coraçõ e de uoontade ficarõ concordados. E depois quãdo sua filha soube de çerto que elles eram auỹdos, aynda que lhe deram todo o mũdo por sseu nõ ouuera en ssy tamanho prazer como entom auya. E por tal de auer conssentimento da rraynha sua madre, ElRrej enuyou por ella e lhe contou toda a uerdade da cousa queianda era, a qual soomente por squiuar noio e desaueença e desy por conplazer a sua filha conssentyo e afirmou o que antre elles foy acordado. E esto era de maraujlhar, porque nom auya homẽ en toda aquella terra que soubesse em çerto dõde [8vb] el biera, senom el soo. Por [sic] quãtos com el conuerssarõ, per suas obras bem sentirõ que el bynha de gentyl sãgue e que, nom enbargando que ella en ssolido herdeira fosse de sseu padre, que ele assaz de siso e entendimento auya pera rreger e gouernar aquel rreyno. Per esta guisa El-Rrey e a Rrainha, por nom toruar o grande amor que auya antre elles, teuerõ por bem de conssentyr o que queriam.

${ }^{34}$ Para el tratamiento elaborado de la «triganza» en causas de Amor, ver Confessio, libro III ( Aqui falla o Confessor contra aquelles que nas causas d'amor per aazo do sseu gram trigamento falleçem d'arrecadar o que deseiam, e conta por enxenplo hũa fabulla do que aconteçeo ante Phebus e hũa fermosa uirgem que auya nome Dafna»). 
[Capítulo XIV] En como Apollyno casou cõ a filha dEl-Rrey e a enprenhou dhüa filha.

[O] dia do casamento onde Amor he senhor do coraçom pareçe mũỹ tardinheiro ante que uenha, mas em fym chegousse o tenpo en que elles cõ grandes ofertas e sacrifiçios forõ casados, no qual foy ordenada hũa tal alta e custosa festa que a nobreza della per toda a terra foy ssoada. Ca os caualleiros nouees naquel dia justarõ, dançarõ e fezerom todo o prazer que podiam; os herautos e jograres, suas altas uozes ameude braadauã as largesas contra os senhores que hi stauã. Assy que em mujto prazer e allegria foy leuado aquel dia ataa o cabo. Mas depois que a noite scura ueo, este senhor que tynha guãçado o sseu amor lanc[,]ousse em sua cama com sua molher, onde antre ssy ouuerom conprido prazer, que ao depois pareçeo bem a olho, porque anbos antre [9ra] seus jogos tomarõ tanta allegria, de que foy geerada hũa filha, aa qual foi destynado de padeçer mujtas tribullaçõoes.

[Capítulo XV] Aqui conta da morte dEl-Rrey Antiocho, ymjgo de Apollyno, que logo encamjnhou com sua molher p[er] a hir a Tyro, e de como ella no mar paryu hüa filha que ouиe nome Thaysa.

[P]ois dicto hey do casamento destes anbos, daqui en diante contarey das stranhas maraujlhas que lhes depois aconteçerõ per tenpos desuayrados. Assi aconteçeo hũu dia que El-Rrey e a Rraynha con peça de gẽtes se forom a cauallo pera a praya do mar por sse desportar, onde aconteçeo que birom bỹr contra a terra hũa naao mũỹ fermosa. E por saber donde era e a que bynha aguardarõ ataa que chegou ao porto e lançou ancora. Pergũtarõ entom donde era e o que buscaua, e elles respõderõ: «Somos de Tyro e bỹmos buscar Apollyno, que he nosso Rrey e uerdadeiro senhor». O qual, seendo mũỹ ledo, chegousse pera alla e elles lhe contarõ nouas de grande prazer com grande allegria, contandolhe en como Deus tomara byngança sobre El-Rrey Antiocho e sua filha, os quaees com ffogo de corisco forom feridos a morte. «E, por ende, senhor, ẽ nome de toda a uossa terra e senhorio de Tyro, de sseu [9rb] mandamento uos suplicamos que, leixãdo todallas outras cousas, uos praza de birdes bisitar uossos sojeytos e uerdadeiros serujdores, cõ outros uossos parentes que jũtamente com grande soydade stã aguardando polla uossa hida». Tanto que El-Rrey Artestrates ouue notiçia daquella cousa, as nouas dello logo forom spargidas per toda a çidade de Pentapollym e o prazer que entõ antre ssy ouuerom era sem conto. Ca todos geeralmente diserom a hũa uoz: «Honrrado rrey teeremos por nosso senhor e o que cujdamos aa primeira que era por nosso mal por a uoontade de Deus he agora hordenado por nosso grande bem».

Apollyno, seendo prestes de todo o que lhe conpria pera bjr aa ssua terra de Tyro, encomendou a Deus o rregno con todo o poboo que em el moraua; e como quer que El-Rrey e a Rraynha por sua partida ouuerom en ssy noio por aquella ora, pero doutra parte allegrarõsse por teer hũu tal filho qual lhe Deus enuyara por sseu grande bem e onrra, assy que antre prazer e pesar este Apollyno e sua molher - que de condiçõ era manssa e omjldosa- entrarom anbos em a naao. E nõ enbargando que ella entom era prenhe, pollo grande amor que antre ssy auyam nõ sse queriam partyr [9va] hũu do outro. 
Lycorida foy dada por ama a esta molher noua, aa qual a pouco de tenpo foy ordenada mũỹ noiosa uyda. $\mathrm{Ca}$, seendo elles ia passados aa meytade do mar, byrom leuantar hũa nuuẽ negra da parte do aguyom, e desy os vẽtos começarom mũỹ brauamente de soprar e o çeeo de sse mexer, e o ssoll com scuridom da noite perdeo seu lume, e a llũa e as strellas per aazo das nuuẽs ficarom çegas. A tenpestade dos toruõoes e rrellanpagos tam fora de rrazõ era grande, que esta rraynha noua com spanto dello começou de chorar e de clamar como aquella a quẽ confforto nem esfforço que lhe seu senhor entom fezesse podia prestar, mas ante jazendo na sua camara bem çarrada bierõlhe as doores do paryr. Polla qual rrazõ El-Rrej mujto ante menhã se leuãtou da par della, assy que em grande noio e tristura paryo de noite hũa filha, no parto da qual quãtos hi stauõ por entõ a julgarõ por morta. Apollyno quãdo esto soube com noio dello cahiu smoreçido en terra de tal guisa, que todos cuydauõ que era ja finado deste mũdo. E depois a cabo de tenpo, quãdo acordou, fez por ella seu planto em esta maneyra:

«Oo molher mjnha e todo meu [9vb] prazer! Oo meu sollaz e todo meu deseio! Tu es mjnha boa andança e todo meu rrelleuamento. Pois assy he que mjnha ynffortuna quer que tu aias de morrer, eu nõ ssej pera que a mjnha ujda pera mais longe seia p[ro]lõgada. E tu, Fortuna, que agora me as feito o pior que podes, daqui en diãte pera ssenpre eu te despreçarey. Oo coraçom! Por que nom rrebentas ora por tal que em aconpanhando mjnha senhor a pena que padeço seia mais pequena?».

Em chorando e fazendo seu conplanto per esta guisa myl uezes beyiaua sua molher, que ia entõ jazia finada ante seus olhos. Que uos direy mais? Nõ ssey fallar de sseu mal. Tam grande era e tanto que quãtos o birom o julgarõ pollo mais triste e mais noioso de quãtos nũca birom. Assy que el, como homẽ que pareçia sandeu, ora sse lãçaua, ora sse leuantaua, ora pasmaua e perdia a falla, ora alleuãtaua braados temerosos e outra ora com pallauras dooridas damor pidia aos deuses que rresuçitassem sua senhor ou dessem acabamento a sua ujda. Seendo El-Rrey em esta coita, o meestre da naao e outros marinheiros em sua conpanha chegarõ a el dizendo:

«Senhor, uos bem sabees que a ujda da Rraynha uossa molher por grande noio que uos [10ra] tomees nem aynda que uos por ella matees nom pode sseer rrecobrada. E sabees outrossy en como o mar de sua propria naturalleza nom quer sofrer en ssy criatura morta algũa que rrazoauel seia. Por ende, consyrãdo o grande perigoo en que stamos com esta grande tormenta, consselhamos a uos e de merçee uos pidimos que lançees fora da naao esta fynada; ca mjlhor he ${ }^{35}$ que ella uaa fora, pois ja nom pode aproueitar, que uos e nos outros todos seermos aqui perdidos».

El-Rrey ueendo a uoontade delles queianda era, e esso meesmo que the consselhauõ que era uerdade, com piedade dos outros mais que por ssy meesmo começou desfforçar quanto quer seu coraçom. E disse em esta guisa:

35 'he': 'q he', 'q' tachada. 
«Bem ssey que uos me dizees toda a uerdade. E por ende querouos mostrar como por conplazer a mjnha pessoa soomente eu nõ queria que a uos outros aconteçesse cousa contrayra; ca, pois assy he que esto que uos dizees per fforça conuem que seia ffeito, fazee logo bỹr aqui hũa arca de bordos fortes mũỹ bem çarrada cõ pez e cõ chunbo».

A qual logo em hũu ponto foy acabada e tragida aa ssua presença. Tomarõ entom a fynada e, ella primeiramente cosida em pano douro, poserõn[10rb]a dentro em aquella arca. E por tal que en chegando aa costa do mar o corpo achasse mais asynha sopultura queianda the perteeçia, fez meter dentro na arca hũa grande soma douro e outras mũỹ rricas joyas cõ hũa carta que dizia em esta guisa.

[Capítulo XVI] Tresllado do scripto que Apollyno mãdou poer so a cabeça de sua molher e como leixou dhjr a Tyro e foisse dereito pera Tarssea.

«[A] quantos esta birem ou ouuyrem, eu, rrey Apollyno de Tyro, faço saber que em esta jaz fynada a filha dhũu rrey, a qual por agora nõ tem outra maneira en como possa seer acorrida; e porem rrequeiro a qualquer que primeiro açertar de a achar que aa onrra de Deus e por caridade com este thesouro a queira enterrar en llugar onrrado».

Scripta esta carta, çarrarom a arca e pregarõna mũỹ fortemente com çyntas de ferro, por tal que as uagas a nõ rrebentassẽ; e desy çarrarom as fendeduras de fora com pez e com chũbo e encoyrarõna per tal guisa que a auga nõ auya poder dentrar em ella. Assy que em sperança que o corpo arribasse ẽ saluo em algũa terra lançarõno entõ fora ao mar sem mais tardança. [10va] Este nobre prinçipe Apollyno andãdo no mar mudou seu primeiro proposito, dizendo aos mareantes da naao que el por entom scusaria a hida de Tyro e porem que se encamjnhassẽ dereito pera Tarssea. O meestre marinheiro, por conprir a uoontade de seu senhor, tanto que a tenpestade foy çessada guyou a naao dyreitamente pera hu el mandou.

[Capítulo XVII] En como Cyrimõ o phisico achou o corpo da fynada en terra açerca da çidade de Ephasym e como achou em ella o pulsso de tal guisa tenperado, que prouando em ella sua grande mesteria lhe fez cobrar ofolgo que em ella era mortifficado.

[T]ornando outra uez aa materia de que ante começey a fallar, segundo contam os lyuros antigos, esta fynada de que eu ante disse antre o uento e as hondas do mar foy lançada ora aca oralla, ataa que o mar lançou a arca em hũu lugar chamado Ephesym. Ora quem ouuer sabor descujtar a maraujlha desta storia podera entender que quẽ Deus quer guardar cousa algũa lhe nom pode enpeeçer. Tanto que este corpo foy lançado en terra, açertousse de bỹr per hi hũu gram meestre ẽ phisica e çellorgia per nome chamado Çyrimom, o qual ẽ estas sçiençias [10vb] anbas era mũy uallente leterado qual nõ auya en todas aquellas terras. Este meestre, logo como chegou aa praya onde a arca jazia, porque a achou pesada, cujdou em seu coraçom que bynha em ella grãde algo e mandou a esses seus disçipollos que com elle hiam que ssem mais deteença a leuassẽ pera casa. 
Teendo elle esta arca bem fechada dentro em sua camara, buscou engenho en como fosse logo abrida. E quãdo byo o corpo enbrulhado ẽ pano douro e o thesouro e a carta, per que soube parte da uerdade, descoseu logo o pano por ueer o corpo ẽ que ponto staua. E porque o byu fresco que nom fedia, como nobre e exçellente leterado praticador das cousas que perteeçiam a ssua sciençia de phisica, ueendo en como ella era molher de ydade assaz mãçeba começou primeiramente de prouar o pulsso della e buscar outros mujtos sinaaes que perteeçẽ aa ssabedoria desta sciençia. Pollos quaees achou que cobraria ujda en lhe fazendo sua cura com dilligençya. Mandou entõ tirar o corpo mũỹ onestamente fora da arca; o qual lançado em hũa cama molle, cõ lenço[ ] oes queentes fez squeentar os seys peytos frios. E esso medes todo [11 ra] feito en tal guisa, que antre os yngoẽtos e a quẽetura e olleos mujtos que lhe poserom, e espiçialmente por lliqor que lhe el mãdou lançar polla boca, o qual a grandes leterados he pouco conheçido, o coraçom della começou de aqueeçer e latejar. Assy que polla cura mujto boa que este gram meestre ẽtom fez, naturalleza começou obrar em ella, per tal modo que abryo os olhos e des hi per tenpo rrecobrou en ssy força, lançando as mãaos pera o alto, dizendo mũy dooridamente, como molher que staua fora de ssy: «Oo ssenhor Deus, en que lugar stou ora eu? Que mũdo he este? Onde sta meu senhor El-Rrey?» Mas Cyrimõ, o nobre phisico, rrespondeo e disse: «Senhora, uos em saluo stades aqui, e por ende eu uos conselho tomees ê uos confforto quanto poderes. Ca seede çerta que a uos nom falleçera cousa que de rrazom uos seia fazedora».

Depois, a cabo de çertos dias que ella en ssy tyjnha cobrado seu entendimento, o meestre, por saber quejanda era sua entẽçõ, pergũtoulhe cuja filha era e por todo o caso que the aconteçera. «Meestre,» disse ella, «o modo en como eu aqui som bỹnda nom uollo saberey dizer, mas de todollas outras cousas que eu antes padeçy soo bem nẽ[11 rb]brada». E contoulhe entom de põto a ponto a uerdade da cousa como fora. E el meesmo de sseu cabo disselhe per que guisa a achara em hũa arca bem fechada, descubrindolhe ajnda mais do thesouro que bynha dẽtro com ella, o qual el dizia que ella a todo tenpo tynha bem prestes a sseu mandado, e el medes de sseu cabo en todallas cousas que a sseu serujço conprissem dhi en diante e lhe queria sseer senpre obediente. A qual cousa lhe ella gradeçeu mũỹ muyto como a homẽ en que toda sua fiança era ia posta. E porẽ começou logo de lhe descubryr todo o que tyjnha na uoontade dizer do que ella entendia: çertamente que El-Rrej seu senhor e sua filha eram ia perdidos no mar e que, pois assy era, que nom podia scusar de biuer senpre noiosa, e que porem propoynha em seu coraçom de nũca jamais curar da ujda deste mũdo. Mas, por tal de guardar e manteer castidade pera senpre, rrogoulhe mũỹ aficadamente que lhe ordenasse sua morada em algũu tenplo antre molheres honestas e de boa ujda. Tanto que o meestre sentyu sua entençõ queianda era, dentro em seu coraçom ficou ẽde mũỹ ledo, prometendolhe que em logar daquello que auja perdido que elle aa ssua propria despesa lhe daria hũa [11va] sua filha pera a auer de serujr em quanto biuesse. "Desto e de todo o al que me auees feito", disse a Rrainha, «eu uollo gradeço muyto; Deus uos de ende uosso guallardom, pois em meu poder nom he de uollo dar». Per esta guisa andou ella padeçendo hũu tẽpo ataa que prouue a Deus de lhe dar esfforço e foy sãa. Entom per consselho danbos foy asynado o dia en que ela e a filha daquel meestre ouuerem dẽtrar em 
hordem. Na qual <no qual $>$ uestidas de preto com proçissom e grande festa e sollepnjdade se obrigarom a rreligiom segundo a rregra do lugar onde Dyana era santificada.

Ora leixarey de fallar desta senhor que he posta em hũa ordem, ẽ a qual pera ssenpre entende de biuer, e tornarey a rrecontar dEl-Rrey Apollyno, seu marido, que andou syngrando pollo mar ataa que chegou ao porto de Tarssya de que eu ante disse.

[Capítulo XVIII] En como Apollyno deu a criar sua filha ẽ Tarssia e dhi se ffoy a Tyro.

[T]anto que foy sabudo polla çidade que el era byndo, todos geeralmente com uoontade que aujam de o beer forõno rreçeber com grande onrra. $E$ aynda que el por entom dẽtro no sseu coraçom fosse anoiado, em seu senbrante aa de fora mostroulhes de ssy mũy boa cara. E desy aderençou pera casa do sseu [11vb] ospede, onde el foy mũỹ bem rreçebido. Depois que todo o poboo foy hido, el chamou Strãgullo, seu ospede, a de parte e as infortunas que lhe auyerõ todas lhas contou a meudo. Dizendolhe aynda que, por quãto el e sua molher eram daquelles en que el mais fiaua, que por sua uoontade era por hũu tenpo de lhes dar encarrego de Taysa, sua filha, se a elles prouuesse de o fazer; rrogandolhes que, como ella chegasse a idade, que a fizessẽ poer em scola pera aprender, fazendo seu uoto e promjtymento a Deus que nũca por seu amor mandaria rrapar a barba ataa que en llogar conujnhauel a seu stado a uysse casada. Elles, acordados sobresta materia, Apollyno per hũus poucos de dias ficou ally por sse desportar. E des hi spediosse delles e aderençou per mar alto aa ssua çidade de Tyro, onde todos geeralmente com grande deseio o olhauõ cada dia por sua bynda. $E$ tanto que ouuerom bista da naao e souberom de çerto que el bjnha, nũca foy çidade no mũdo en que tãto prazer fosse tomado como entõ foy em ella. $\mathrm{E}$ pollo prazer que as gẽtes filhauõ o sseu coraçom se começou de allegrar hũu pouco.

Pero esta Fortuna per desuayrados modos em gram trabalho se gisou a ujda deste nouo rrey. Mas, nom enbargante [12ra] que el assy fosse conbatido de muytos noios e tribullaçõoes, ssua fym, porem, aa derradeira foy mũy boa.

Ora, tornando a fallar de Thaisa, sua filha, que leixou ẽ Tarsya, segundo conta a cronyca, ella foj mũy bem criada e guardada, ẽ tãto que na sua criaçom do que auya mester nõ padeçeo mỹgua. E em feito de sua scolla tanto aprendeu, assy das boas enssynãças e costumes como doutra leteradura, que em saber nõ auja en toda a terra semelhante a ella.

[Capítulo XIX] Aqui falla en como Dionysia, molher de Strangullyo, por enueia mandou matar Thaisa, filha de Apollyno, $\langle e\rangle$ entregandoa a hüu seu seruo que a matase lonje da çidade de Tarssia.

[F]alssa ẽueia, con que a Deus nom praz, obrou depois cousa tal, que Thaisa en grandes afliçõoes foy posta. Ca assi foy que este senhor Strangullio, que della tjnha encarrego, naquelle tenpo teue hũa filha, per nome chamada Phillotemya. E fama, que nunca queda de correr polo mũdo, chegou aas orelhas de De- 
onisya, sua madre, dizendo que em qualquer lugar que sua filha cõ Taisa andasse ou steuesse assẽtada que todos geeralmente fallauõ da sabedoria e fermosura de Taisa, e de sua filha nõ auyã memoria. Polla qual cousa Dyonjsia, sua [12rb] madre, foy en ssy tam sanhuda, que cada hũu dia lhe pareçia mjl anos, ataa que podesse tomar byngança sobre esta uirgem fermosa. Ora assy aconteçeo que Licherida, que era ama e leal seruente desta Taysa, pouco auya que fynara, assy que ella per mj̃gua de Licherida padeçeo mujto mal, por quãto todo o serujço que lhe era feito bjnha da parte de Dionysya, que era sua mortal inmjga. A qual conpassou hũa sotil traiçõ em esta guisa. Ella mandou chamar hũu seu seruo, que auja nome Theophillus, ao qual deu logo seu juramento en puridade, e lhe mãdou que posesse em obra o que lhe ella diria. Entom lhe asynou tenpo çerto ẽ que auja de bỹr calladamente por esta uirgem e a lleuar a hũu logar çerto jũto com o mar onde a matasse, per guisa que o alguẽ nom bisse. Quãdo o seruo soube sua entençõ, cõ temor da byngança que lhe por ello poderia bỹr o sseu coraçom se tornou mũỹ mujto, mas enpero nõ ousou a dizer de nom. E porem juroulhe que o seu mandado segundo sua uoontade seria conprido.

Chegado o dia en que esta falssa traiçom auya dauer acabamento, o seruo leuou esta uirgem jnoçente aa rriba do mar, onde lhe Dionysia asynara, e des hi tirou hũa spada fer[12va]rugenta que tragia, dizendo: «Tu morreras agora aquy sem outro rremedio». «Oo ssenhor Deus!», disse ella, «por que rrazom?» «Porque mjnha senhora», disse el, «me tem mandado que te mate». Ella entom com grande medo da morte começou de gritar mũỹ altamente, rrogandolhe por amor de Deus e por saluaçom de sua alma que lhe desse tanto de spaço que podesse fazer sua oraçom a Deus em giolhos ante que morresse. Com o qual arroido e gritos tam altos que ella daua çertos cossairos, que hi açerca jaziam ascondidos tras hũa rriba de penedos em hũa barcha sahirõ a pressa fora. E quãdo o ujllãao seruo ouue deles bista pos os pees ao camjnho fogindo quãto podia. E ella de seu cabo braadaua contra elles, dizẽdo: «Oo senhores, acorreeme aqui por amor de Deus ante que nom moyra!» Leuarõna entom pera sua barcha como ladrõoes que eram e foronsse ao mar, onde, assi como Deus quis, o uẽto com tormenta mũỹ grande per fforça os leuou ao porto da çidade de Antellena. Onde depois que arribarom em saluo o meestre da naao aderençou logo pera a çidade e pergũtou se auja hi alguem que quisesse conprar esta uirgem Taysa. E quãdo Leomyno, que tynha encarrego das mãçebas da mançebya, soube daquello [12vb] parte, disse ao meestre que fosse logo por ella. $E$ tanto que anbos forom aujdos sobre o preço, Leomyno, por dauer por ella mayor proueito, fez apregoar, que qualquer que quisesse atentar ou prouar a ssua uirgjndade que lhe desse çerto preço douro e elle lhe daria logar pera ello.

[Capítulo XX] En como Leomyno em hũa casa partada meteo Taysa dentro na mançebya, e por sseu grande planto e mujta tristeza algũũ no[ ] ousou de se atreuer a dormir cõ ella.

[D]ado o pregom per toda a çidade, em bista de todo o poboo foy Taysa leuada aa mancebia. Nõ he de maraujlhar se ella cõ tanto mal e desonrra ouue noio. $\mathrm{Ca}$, seendo ela soo apartadamente em hũa camara, dez ou doze mançebos per spaços hũu en pos outro entrarom onde ela staua. Mas non enbargando o maao deseio de luxuria que os fez alla chegar, prouue a Deus que, tanto que 
bjrom o noio e pesar com planto que ella fazia, nenhũu delles auya poder de chegar a ella por lhe fazer desonrra. Quãdo Leomyno esto soube, com grande manẽcoria mãdou a hũu seu serujdor que logo per força dormysse com ella. $\mathrm{O}$ qual, oolhando suas querellas e pallauras tan doridas, moor sabor ouue de chorar que de fazer o al que lhe seu amo [13ra] mandaua.

Esta uirgem seendo assy guardada do biltamento de sseu corpo poss $<\mathrm{s}>\mathrm{e}$ em giolhos ante este homem e disselhe:

«Se meu senhor per mỹ quiser guãaçar algo, nom he este o camynho pera el muyto percalçar. $\mathrm{Ca}$, sse me quiser tirar desta casa e me poser em lugar honesto onde molheres rrelligiosas e de boa ujda moram, eu lhe darey camjnho en como per mỹ aia grãde proueito. Por ende uos rrogo que digades a uosso amo que, depois que me el poser apartada antre ellas, entõ faça apregoar per toda a terra arredor que, sse hi ouuer caualleiro ou senhor ou outra pessoa onrrada que deseie de teer sua filha bem enssynada, que eu the enssynarey cousas nouas de bem quaees outra molher deste rregno nõ sabera fazer».

Ditas estas pallauras, tornouse o homẽ a sseu amo e contoulhe todo o que lhe ella disera. E el, ueendo ẽ como na mançebia nõ poderia per ella auer proueito, mãdou a sseu serujdor buscar algũu lugar onde ella steuesse, por tal que per o que ella sabia podesse sequer cobrar o que lhe custara. Assy que este Leomyno a tirou entõ fora da mançebia, nõ pollo de Deus mas por com ella guãaçar. Dhi ẽ diante as molheres nouas de toda a terra darredor beerõ a ella pera apre[13rb]nder cousas desuairadas que antes nõ byrom. E ella, como senhor mũỹ sperta en toda boa sabedoria, spiçialmente nas obras e enssynanças que perteeçem a molheres filhas dalgo e dalto lynhagem, enssynauaas mũỹ de boa uoontade. A hũas laurar de ouro e de seda, e a outras de tãger e cantar com arpa e outros stormentos de musica, e aallem desto de fallar mũỹ cortesmente e outras cousas sotys, das quaees ella tanto sabya que quãtos a ouuyam lhe dauam sobre todas mũy grãde louuor. Assy que per estas cousas e outras mujto boas que ella sabia e enssynaua sua fama creçeo per toda a terra en tal guisa que Leomiyno guãaçou per ella grossamente.

Mas ora leixa a estoria de fallar desta uirgem e torna a Dionysa e seu seruo Theofillo, sobre a morte que lhe per ella foy ordenada, como ante disse.

[Capitulo XXI] En como o seruo Theophillo trouxe nouas a ssua senhora Dyonysa da morte de Taysa, e como Apollyno, acabadas as cortes que fez em Tiro, foy buscar sua filha a Tarssya.

[T] anto que o villãao seruo Theophillo chegou onde staua sua senhor Dionysa, contoulhe logo calladamente en como per suas mãaos matara Taysa e que a tynha soterrada en logar secretario[13va], como lhe ella mandara; e, por ende, por tal que a cousa nom fosse descuberta diselhe que teuesse todo mũỹ bem em porydade. Logo como esta diaboa aquello soube, dentro no sseu coraçom tomou mũỹ grande allegria, cujdando que era assy a uerdade. Daquy en diante scuyta bem e ouuyras hũa grande falssura que esta maa molher entõ conpassou. Ella, fyngjndosse noiosa, começou de chorar e de praça fazer con- 
pllanto, dizendo a quãtos lhe pergũtauõ que, em jazendo Taysa e ella anbas com seu senhor na cama de noite, que ella biera a morrer de morte supytanea. $\mathrm{E}$ porque esta Dionysya era molher onrrada e de grande stado, todo quãto dizia geeralmente foy creudo per toda a çidade. $\mathrm{E}$ aallem desto, por mostrar mayor eujdençia que esto que dizia era uerdade, em synal de doo o marido e ella anbos se uestirom de doo preto e lhe fezerom mũỹ grande e õrrado enterramento. E aynda mais, por çegar as gentes e as tyrar de toda sospeiçom, mandarõ fazer por sua rrenenbrança hũu mũj nobre e mũỹ rrico moymento de latom, segundo o rreal costume que sse entõ vsaua, cõ hũa ymagem jazendo ençyma semelhante a ella nom mais nẽ menos, e a scriptura do moymento dizia em esta guisa:

«Aqui jaz aquella que das molheres ffoy [13vb] auuda por frol em fermosura, cujo nome era Taysa, filha dEl-Rrey Apollyno de Tyro, a qual seendo ẽ jdade de quatorze anos, morte, que a nehũu perdoa ${ }^{36}$, arreuatouha e assy acabou seus dias».

Per esta guisa a falssa trayçom hũu tenpo foy ascondida, ataa que depois se açertou de seer descuberta segundo adiante polla storia poderas seer çerto.

Ora conta a cronyca, tornando aa mjnha materia de que eu dantes falley, que, tanto que el rrey chegou aa çidade de Tyro, logo sem mais tardança fez chamar os senhores de sua terra pera fazer cortes, em as quaees depois que soube as cousas todas como sse pasarom em rrazom do rregimento de seu rregno contoulhas grandes auẽturas e ỹffortunas que padeçera andando fora, e ssobre todo nõ lhe squeeçendo sua molher, que leixara na scuma do mar salgado. Rrogoulhes a todos que aguardassem por hũu tenpo, por quãto entendia de fazer por memoria della hũu saymento onrrado. $O$ ofiçio do qual foy mũỹ sollene a marauylha, $e$ cõ ysso os sacreffiçios eram mũỹ rricos e a ffesta que foy feita em rrealleza nom podia seer melhorada, como aquel que era bem thudo de $\mathrm{o}$ assy fazer, porque em aquel tenpo nõ auya homẽ que em bondade teuesse molher semelhante a ella.

[14ra] Acabada esta festa e onrra que fezera por amor de sua molher, nẽbrousse de sua filha que lhe ficara em Tarsea. E por tal de a trazer a sua terra, rrogou a çertos senhores que dos que hi stauam que teuessẽ por bem de hyr em sua conpanhia, ca el per sua pessoa medes queria hjr por ella. Os quaees, nõ querendo negar ao seu rrogo, fezeronsse logo prestes. E depois que fforom entrados nos nauyos seguyrõ sua rrota, ataa que prouue a Deus que chegarom aa porta de Tarssea, onde do que bynham buscar ficarom fallidos. Ca Strãgullyo e sua molher, Dyonjsya, en cobryndo per ssotilleza sua fallssura, por lhe dar mjlhor a entender o que diziam seer pura uerdade, leuarom Apollyno ao muiỹmento que foy feito pera ella. E como quer que com a bista do mõymento tam bem obrado ficasse en ssy hũu pouco allyuado do sseu nojo, nõ leixou porem de dizer mal a Ffortuna, como aquella en que nehũa segurãça nom auya, pois que tam ameude rrenouaua os seus nojos e tribullaçõoes. Mas em fym, quãdo bju que ao sseu mal nõ auja cobro nem rremedio, louuou mujto a Deus e desy tornousse outra uez pera Tyro.

${ }^{36}$ Sobrescrito. 
[Capítulo XXII] En como Apollyno hjndo pera Tyro per fforça de tormenta aportou na çidade de Mytellena, onde Athenagoras [14rb], rrey della, por ueer Apollyno se foy a naao ante que el beesse ẽ terra.

[A]ssy aueo que, hjndo Apollyno sua biagem pollo mar, tal tẽpestade de uento e chuyua se leuãtou subitamente que lhe conuynha todauya obedeçer aa lley de Neptemos, por a qual cousa se querellaua muytas uezes a Deus e anoiauasse dẽtro en ssy muyto mais, por aazo do que dantes auya passado. Assy que pollo noio e coita que padeçya, uẽedo seu mũdo andar pera mal, leixou dhi en diante de jazer ençima na camara e meteosse abaixo sotilha, onde sem lume de dia e de noyte jouue soo, nõ çessando de chorar continoadamente a ssua tristura sem conssollaçom, ataa que per spaço de muytos dias a tenpestade do uento os leuou aa c[,]idade de Mitellena. E foy en tenpo que os senhores e outros comũees, segundo seu costume, geeralmente çellebrarom alta festa de Neptimus com grandes sacrifiçios e mujtos prazeres. E quãdo birom esta naao strangeira dentro ẽno porto llançar suas ancoras, quãtos na çidade morauõ teuerõ que fallar della todo aquelle dia. O ssenhor da çidade, cujo nome era Athenagoras, staua hi entom quando a naao entrou, o qual mãdou logo aparelhar hũa barca pera hir beer que naao era e que gente bynha [14va] em ella; e tanto que chegou alla bio a naao mũỹ rricamente apostada e de todallas outras cousas que lhe conpriã mũỹ bem aparelhada, e, nõ enbargando que os bisse todos de seenbrãte pesado, pero pareçialhe per sseu modo que erã homẽes onrrados e dalto sãgue. Pergũtoulhes entom quẽ erã e donde bynhã. Elles contarõlhe todo o caso: como seu senhor per fforça de tenpestade se acolheo a aquelle porto, e esso meesmo do sseu noio que tomaua, o qual fora de rrazom era tam grande, que conforto de nehũ homẽ que lhe podesse fazer lhe nõ prestaua. Athenagoras rrogoulhes entõ que o leixassem allo hir pera ueer se lhe fallaria. «Senhor, cousa he que nom pode seer», diserom elles, «porque el jaz em hũu lugar tam scuro, que ajnda que alla uaades nõ enxergarees o sseu rrostro». Nom enbargãdo o que lhe elles diserom, deçeusse pola scaada a füdo e foilhe fallar. Mas por cousa que soubesse fazer nem dizer nũca el pode auer rreposta pequena nem grande. Assy se tornou.

[Capítulo XXIII] Aqui diz en como per mãdado de Athenagoras Thaysa cõ sua arpa foy a naao por confortar Apollyno, o qual em fallando com ella a conhoçeo que era sua filha.

[A]thenagoras, quãdo sse tornou, ouue consselho sobre Apollyno e sua tristeza. E em fym de suas [14vb] departiçõoes que ouue cõ os altos senhores e mũỹ sesudos, foy acordado per todos que a nobre Taysa e fermosa uirgem, que en todallas cousas era molher auysada e graçyossa, fosse logo chamada por tal que este rrey noioso pollo que ella sabia de sseu noio fose allyuado. Mãdarõna entom chamar e ella. Com sua arpa chegou logo, e sobre todos os que hi stauom os da naao lhe rrogarom mũỹ aficadamente que por sua cortesya fezesse sua dilligençia, per tal guisa que seu senhor rrecobrasse algũa cousa desfforço em seu coraçom, prometêdolhe que, sse per algũu desporto ou sotilleza que ella soubesse a tristeza de sseu senhor fosse desuyada, que elles de sseu cabo lhe dariam tal guallardom per que ella ao diante soportaria mjlhor stado e mais honrradamente. Quãdo ella aquello ouuyu deçeusse polla scaada a fundo, onde este nojoso rrey jazia, e começou logo de tanger e cantar mũỹ graçiosamente. Mas el tã pouco 
curou entom do que ella fazia como se fosse hũa pedra muda. Tanto que Thaisa entendeo sua condiçom queianda era, começou de lhe contar storias de prazer, pergũtandolhe de mujtas cousas stranhas, com as quaees o sseu coraçom hũu pouco foy demouydo, como aquel que em parando mentes ao seu fermoso rrazoar maraujlhauasse muyto do [15ra] grande saber que em ella auya.

Pero nom enbargando que el por exẽplos e poblemas [sic] e outras questõoes mũỹ sotys lhe demandaua que julgasse o que entendesse, nũca del pode auer soomente hũa pallaura de rreposta. Mas ante bem, como homẽ fora de sseu siso, chorando desuyou o rrosto pera hũu cabo, dizendolhe cõ sanha que sse afastasse e se fosse sua bia. Mas ella porem nõ o quys assy fazer, e chegousse pera el onde jazia no scuro e tocouho hũu pouco cõ as faldras, polla qual cousa se el tanto assanhou que lhe deu hũa palmada. E quãdo ella byu que sse tanto queixaua disselhe mũỹ mesuradamente em esta guisa: «Oo senhor, paraae ora mentes aa cortesia e a mỹ, que soo hũa uirgem, que sse uos soubessees a lynhagẽ donde eu desçendi creo bem que mujto uos aujsarees de mostrar contra mỹ tal braueza qual nõ conuem a tam nobre senhor qual dizem que uos soes.» $E$ cõ esto começou elle de tenperar seu coraçom [15rb] e allegrar hũu pouco o ssenbrante. Per estes anbos pode homẽ aprender a obra que naturalleza mostra antre aquelles que ssom dhũu sangue, ca, nõ enbargando que o dyujdo antre elles era scondido, aynda que fosse tam chegado, pero o padre, nom sabendo por que, aa boa ffe cõ todo seu coraçom naturalmente amou esta uirgem con que fallaua. Mas ante que sse anbos partissẽ prouue a Deus que a uerdade de todo seu feito foy sabuda per esta guisa.

Entom pergũtou El-Rrey a esta uirgem que lhe dissese o sseu nome e de que linhagẽ bynha e onde aprendera aquelles jogos. E ella rrespondeo aa sua pergũta e disse: "Senhor, a mỹ chamom Thaysa, que em seendo moça pequena fuy criada em Tarssea, onde aprendy esto que agora sey. Segundo me a mỹ entom foy dicto, meu padre era hũu Rrey, mas nõ soo acordada donde, e que mjnha madre fora allagada no mar.» $E$ desy en diãte começoulhe de contar o que longamente tynha guardado en ssy dentro que o nom ousaua descobrir a nehũa pessoa do mũdo. Entom de todo en todo pollo meudo contou a este senhor o caso de ponto a ponto, ao qual ora beesse dello mal o bem o seu coraçom nõ sse podia encobrir que lhe nõ dissesse todas suas ynfortunas que antes padeçera. Seu padre, sabendo ia de çerto que ella era sua filha, con todo prazer a tomou nos braços como aquel que com a grãde allegria que dello auya nõ sabia entom onde staua. Assi que estes que antes stauam mujto anojados, como sse conheçerõ ficarõ mũỹ confortados, e dhj en diante Fortuna jurou de o fazer sobyr na rroda, assi como ueemos o mũdo ãdar ora bẽ ora mal.

[15va] [Capítulo XXIV] Aqui diz en como Athenagoras [casou cõ Thaysa], filha de Apollyno, o qual hjndo pera Tarssea foilhe rreuellado que sse fosse a Eph[e]s $\tilde{y}^{37}$.

[E]ste rrey, sentyndo a graça que lhe Deus dera, nouamente tirouse do logar scuro en que antes jouuera. E tragẽdo sua filh $<0>[\mathrm{a}]$ conssigo beosse açima onde os outros stauã, e desy forõsse anbos pera a camara que pera el era hordenada,

\footnotetext{
${ }^{37}$ Arriba en el margen superior dice: «caso cõ Taisa».
} 
onde os panos pretos que ante trazia bestidos despio [sic] e uestyosse de panos rreaaes queiandos a seu stado perteeçiam. Sahiosse entom pera fora, onde achou Athenagoras, que o estaua aguardando, o qual cõ pallauras de grande mesura lhe rrogou que quisesse hjr ueer o sseu castello e a çidade toda. Foronsse entõ todos tres pera os paaços daquel senhor que os assy conujdara, e lhes fez mũỹ rrica e custosa festa con todo outro honesto gasalhamento en que entendia de conplazer a este Rrey onrrado. E por que este Athenagoras fosse hũu senhor rrico beadante e de mũ̃̃ grandes apostamentos, elle ataaquel dia nũca fora casado; e assi the aconteçeo como a homẽ que aynda entom de dias era bem nouo, que lhe entrou no coraçõ aquel praziuel noio e allegre pena damor, a cujo poderio nehũu homẽ naçido pode rresistyr. O qual senhor, penssando en ssy que se El-Rrej lhe nom fezesse graça que o seu mũdo [15vb] de todo seria perdido, e buscou tenpo e lugar, como homẽ a que pareçia quem o coraçom lhe queria rrebentar, por fallar a El-Rrej e a esta uirgem sua filha pera casar com ella. E en cabo o que deseiaua segundo seu proposito todo lhe foy outorgado, en tal guisa que ela casou cõ el, e assy en boa lyãça ficarom todos concordados.

Acabada a festa da honrra do casamento, El-Rrey contou a Athenagoras, seu filho, a estoria da traiçom que fora conpassada a ssua filha em Tharssea, dizendolhe que el e sua molher beesẽ em sua conpanha pera tomar byngãça sobre aquelles que aujam feito tamanho alleyue. Os nauyos mũỹ asynha forom prestes, e elles como birom tenpo ssem mais tardança segujrõ pera Thassia sua rrota. Mas aquelle alto Deus, sabedor das cousas que ham daconteçer, jazendo este Rrey onrrado em sua cama, mãdoulhe que sse fosse camjnho de Efessym e que ally fezesse seu sacrifiçio como entom mandaua sua lley; dizendo aynda mais que no tenplo, presente todos os que hi steuessẽ, contasse a grãde enfortuna que lhe aconteçera en rrazõ de sua molher e de sua filha. El-Rrey maginou mujto que poderia signjficar esta bisom que lhe Deus demostrara. [16ra] E tanto que foy menhã fez amaynar treu e lançar ancora, e em jazendo assi de pouco o uẽto que antes era contrairo subitamente tornousse pera onde elles aujam dhir. Entom entendeo elle çertamente que a Deus prouue de lhe mostrar de noite per bisom o camjnho que el auya de leuar, e mãdou ao meestre da naao que logo sem deteença se aparelhasse pera sse hyr dereitamente ao porto de Ephasym. E logo assy foy feito. E tãto que aportou ante a çidade, logo ẽ outro dia sahio en terra pera conprir o mãdado daquel que o allo enujara. E como bio a menhãa, seus filhos Athenagoras e Thaisa cõ outra mujta gente em sua cõpanha encamjnharõsse dereito pera o tenplo de Diana a deessa. Quãdo os da çidade ouujrom dizer que hũu Rrej bynha fazer sacriffiçio aa dessa, foronsse todos alla pera ueer sua pessoa cõ a ssollenjdade da onrra que entõ auja de fazer.

\footnotetext{
[Capítulo XXV] Aqui diz en como Apollyno fazendo seu sacrifiçio no tenpllo de Diana achouha sua molher.

[A]companhado de onrrados caualleiros e cõ boa tẽçõ entrou El-Rrey no tenplo, onde com grande deuaçom primeiramente contẽplou dentro en ssy e se mẽfestou calladamente, e des hi cõ deuuda [16rb] rreuerença ofereçeo mũỹ grandes rriquezas a maraujlha. E depois que esto todo ouue feito, en presença de quãtos hi stauam contou pollo meudo as jnffortunas que lhe ãtes aconteçerom. $\mathrm{E}$, assi como Deus quis, sua molher, seendo abbadessa daquel lugar, açertousse
} 
destar ally aquella ora, a qual, em scujtando a estoria que el contaua, conheçeoho logo pola falla e pollo rrosto, e com prazer que ouue quãdo soube quem el era, trigosamente se ffoy pera elle e cõ allegria cahio smoreçida nas lageas do tenplo. Lançarõ entom auga sobre ella ataa que outra uez foy tornada a sseu acordo, e desque teue cobrada sua falla disse: «Oo Ssenhor, tu seias senpre louuado, pois ãte que eu morresse me deste a ueer meu senhor e meu marido, que eu cujdey de teer morto!». El-Rrey, oolhãdo esto, conhoçeoha logo e, tomãdoa nos braços, chorando beyjouha mũỹ de uoontade. Tanto que os da ujlla souberom esta cousa, tomarõ por ello mũỹ grãde allegria per mujtas guisas; a hũa, porque El-Rrej achou sua molher, e a outra porque prouue a Deus que tall mjllagre fosse feito naquel lugar. Mas sobre todollos outros [16va] nũca foy homẽ que tanto prazer ouuesse como El-Rrey quãdo achou sua molher byua que cujdaua seer fynada. E depois que foy sabudo per que guisa e cujo aazo sua uyda foy salua, todos geeralmente ouu<u>erom por grande marauylha, en tal guisa que a fama da sciençia de meestre Çyrimõ por seu louuor foy rressoada per toda a terra. Por a qual c[o]usa El-Rrey e a Rraynha lhe rrogarõ mũỹ aficadamente que elle pollo seu quisesse leixar a uylla de Ephesym e hir com elles pera o rregno de Tyro, onde por o estremado serujço que del auyam rreçebido leuaryam guallardom segundo seu meriçimento. E el, entendendoo por seu proueito, o mais asinha que pode ordenou sua fazenda e foysse com elles. Per esta guisa acabarom seus feitos em aquell lugar e tornarõsse outra uez aos nauyos com toda sua conpanha que tragiam.

[Capítulo XXVI] En como Apollyno e sua molher chegarõ a Tyro, óde el fez coroar Athenagoras e sua molher.

[O] rrey, como homẽ que entom tynha conprimento do sseu deseio, disse que sse queria hir dereito pera Tyro. E teendo aa sua uontade o uento, nũca amaynarõ treu ataa que chegarom ao porto desse Tyro, assi como deseauõ, onde cõ mũỹ grande prazer forom reçebidos, spe[16vb]çialmente quãdo a Rraynha e Taysa, sua filha, sahirom en terra. Ca entom o prazer e a llediçe que o poboo en ssy ouue com a ssua bỹda ${ }^{38}$ nom ha hi lyngoa que o possa bem contar. Porque quãtos as birõ todos geeralmente a hũa uoz diserom: «Ex aqui vem a ffonte de toda graça femjnyna». Foysse entom El-Rrey pera a sala e assẽetousse na seeda rreal, mas a rraynha foisse dereito pera a ssua camara, e tãto que birom que era tenpo de comer assẽetarõsse aa mesa. $E$ as festas eram mũỹ rreaaes e os noios ante passados todos forom squeeçidos, allegrando seus coraçõoes com nouo prazer quãto podiam, en tanto que a collor que dantes cõ noio era amarella começou entõ denuermelheçer e rrefrescar o rrostro de cada hũu. El-Rrey ao sseu poboo mostrou grande guasalhado e mũy boo aar cõ ledo senbrante. E a cabo de pouco jũtou as gentes de sseu rregno e fez cortes geeraaes, nas quaees Athenagoras, senhor de Mitellena, e sua molher Taysa forom coroados. Per esta guisa, seendo a terra segundo a ordenança do padre posta ẽ gouernãça, disse El-Rrey Apollyno que el querya hyr a Tharssia por tal de tomar byngança sobre aquelles que auyã trayda sua filha, de que todos geeralmente [17ra] eram contentos, como aquelles que diserõ que o auyam por mũỹ bem feyto.

38 'bỹda': 'lingoa bỹda', 'lingoa' tachado. 
[Capítulo XXVII] En como Apollyno se foy a Tharssya por tomar byngança sobre Strãgulo e sua molher da traiçõ que fezerom a ssua filha Thaysa.

$[\mathrm{O}] \mathrm{s}$ nauyos aparelhados, tomou de gente grande poder e, depois que birom o uento de biagem, leuantarõ as ancoras e gujdarom treu, e des hi syngrarom tanto per mar ataa que chegarom aa çidade de Tharssya. E logo como os çidadãaos e moradores dhj souberom quem el era, sahirõ fora a rreçebello cõ grande rreuerença. El-Rrey contoulhes entom a grande malliçia e traiçõ que Strãgullo e sua molher Dionysya auyam feito a el e a ssua filha Thaysa, que leixara ẽ sseu poder. A qual cousa per ante todos notificada, el, como homẽ que deseiaua paz e nom guerra, rrogou a aquelles da çidade que lhe fezessẽ dereito delles. Os quaees, auendo boo deseio de o fazer, logo sem mais deteença per fforça de gente fezerom prender Strãgullo e sua molher, e elles tragidos a juizo forom achados em culpa da cousa que lhe per El-Rrej foy aposta e des hy sentençiados de sseerem arrastados enforcados e queymados, a qual sentença ffoy logo em elles executada. E todos aquelles que ouuyrõ dizer desta falssidade tam grande louuarom muyto a proujdençia de Deus, [17rb] que fez misericordya com justiça, ca per dereita justiça forom mortos Strangullo e sua molher; e Thaysa, que, per a ssua mjsericordia foy preseruada e mereçeo dauer bem, ficou salua.

[Capítulo XXVIII] En como Apollyno e sua molher, morto El-Rrey Arthestrates, forom coroados por reys de Pentapolly.

[D]epois que esto que dito hey foy de todo acabado, este rrey Apollyno, seendo bem quisto de muytas partes, rreçebeo hũa carta que lhe per mar foy enuyada da çidade de Pẽtapollym, ẽ a qual todo o poboo da terra lhe fez assaber en como El-Rrey Astrathes, seu padre, seendo de paz e em boa memoria, se fynara deste mũdo. E por ẽde todos geeralmente ẽujarom pidyr aa ssua merçee que lhe prouuesse de parar mentes a esta $\operatorname{carta}^{39}$ que lhe ẽujauõ e se trabalhasse de bỹr asynha rreçeber aquelle rregno que lhe Deus e a ssua boa fortuna auya dado. Per esta guisa, sẽedo este rrey primeiramente rrequerido per os comũes daquella terra, cõ todollos nobres senhores que com el bynham, spidiose dos de Tharssya e tornousse outra uez pera seus nauyos. $O$ uento era mũ̃y boo e o mar prano, ẽ tãto que nom lhes fazia mester de tirar soo hũa moneta do treu, ataa que chegarom aa çidade de Penthapollym, onde os da terra ouuỹdo nouas da sua bynda eram mũỹ ledos. Depois desto, a cabo de dous dias ou tres, [17va] auydo primeiro seu consselho, asynou hũu dya çerto en que faria cortes geeraes, nas quaees per conssentimento de toda a terra el com sua molher por sseu grande bem e onrra forom anbos coroados.

$* * *$

[Confessor]: Para ora mentes quãto bẽ vem ao homem que leua boo fundamento. $\mathrm{Ca}$, porque este rrey se fundou sobre honestidade de casamento, el senpre logrou seu amor ${ }^{40}$ honestamente e, auendo filhos de ssua molher, biueu de hj en

\footnotetext{
39 'carta': 'terra carta', 'terra' tachado.

40 'amor': 'casamento amor', 'casamento' tachado.
} 
diante mujto aa ssua uoontade. $E$ po[r] enxenplo e rrenenbrança dos que bem amã esta sua ujda foy posta em cronyca, por tal que elles fossẽ çertos que o seu amor na fym sera mostrado queiãdo he. Ca doutra parte se quiseres parar mentes, acharas en como Anthioco - com sua soberua, que contra naturalleza acustumada husou de sseu amor por maao delleyto - rreçebeo depois peendença, como aquelle que per bygança contra naturaleza subitamente ouue maao acabamento.

Por esto, filho meu, tu podes aprender que cousa he amar em boa maneira $e$ em outra guisa, e en como o guallardom dello proçede soomente do serujço; ca, aynda que Ffortuna en sy nom seia stauel, ella aas uezes he fauorauel a aquelles que em amor som uerdadeiros. Mas he dauer pesar do amor que he husado contra Naturalleza, porque he cousa que traz [17vb] os homẽes a maao acabamento, assy como de suso me ouuyste dizer. Porem, filho meu, eu te consselho que leixes dhusar do outro amor, saluo onde amor e rrazõ anbos a boa fym seiam concordados. Ca doutra guisa se tu per $<$ dereito $>$ delleyto, assi como faz o bruto anymal, quiseres desujar o camjnho que deues teer, o teu amor em nehũa guisa pode seer boo e nẽ onesto. Ca eu per rrazom nõ acho ẽ meu juizo en como delleytamento soo possa seer da naturalleza do amor uerdadeiro.

Amante: Padre meu, como quer que seia meu feito em rrazom desta materia, eu o uosso rrazoar hej bem scujtado e entendido como cousa que de grande enxenplo e proueitosa deue seer ouujda e notada. Mas deste ponto soo me posso bem scusar, que eu ataaqui nũca endoudeçy, saluo naquelle onrrado logar onde todo delleytamento e toda graça he posta, se aquel maao bischo Daũger nom fos$\mathrm{se}^{41}$. Ca eu nom sej a que chamades Fortuna, mas que Daũger he eu o hey mũy bem prouado. Porque ao tenpo que o meu coraçom tenho mjlhor aparelhado e o meu ẽte[n]dimento ${ }^{42}$ mjlhor prestes pera lhe pidir cousa de meu amor, nom en-

${ }^{41}$ En el libro III, rúbrica «Aqui põe o Confessor contra aqueles que nas causas dAmor per uontade arreuatada agrauam ssy meesmos e conta sobr'ello hũũ enxenplo que aconteçeo de Piramo e Tysbe» (cap. LXV del texto castellano), se lee la definición más amplia de Danger de todas las que aparecen en la Confessio. «Amante: «Digouos, padre, que Daunger he chamado em algũas terras, que tanto quer dizer como 'nom querer conssentyr', o qual he consselheiro de mjnha senhor. Porque eu nũca tam sotil fuy, em chegando ao logar onde ella steuesse, que eu este Daũger senpre aprestes nõ achasse. [...]. Este tem mjnha senhor assy atada, que ella nom quer que elle de ssy seia departido. Ca senpre se pendura no treu della e he tam chegado do sseu consselho, que tanto que eu algũa cousa lhe uou demandar logo eu acho Daũger ẽ sseu logar e me da senpre mjnha rresposta. Mas por quãta merçee lhe eu demando nũca em merçee pude cobrar. E assy Daunger de mjnha fortuna he gujador, en tal guisa que peor nõ me pode hyr. Mas se eu fosse tam uallente que este me ẽmjgo podesse bençer, assaz de prazer ẽ mỹ auerya. E uos creede que por pecado nõ lleixaria, nẽ aynda por auer todo o mũdo por meu, se eu algũa sotilleza podesse achar por cujdar de poer por ello o meu stado em uẽtuyra da corte o ffaria degradar de maneira que nũca pera ella mais tornasse. $E$ por esto deseio eu e de grado queria que elle per algũu modo fosse todauya morto. Ca çerto soo que em quãto elle em aquelle llogar steuer, nũca de mjnha senhor poderey guaançar graça. E per esta guisa tenho odio mortall a este biçio e queria que nom teuesse ofiçio em logar onde mjnha senhor steuesse. Porque se o elle teuer, eu sej de çerto que ante de poucos dias conuem que hũu de nos aia de morrer.»

42 'ẽte[n]dimento': 'cor ẽte[n]dimento', 'cor' tachado y 'ẽ-' añadido al margen izquierdo fuera de caja. 
bargando as mjnhas rrazõoes que lhe eu diga, senpre soo concludido com [18ra] esta silua: «Nom». A qual en ssy he de grande poder, en tanto que derriba myl pallauras das mjlhores que eu em mjnha maginaçom sey deuysar. Assi que em fym eu fico como homẽ lleigo en que ha mũỹ pouco rrecado.

Mas, padre meu, por quanto uos damor auees grande conheçimento e esta materia - en que eu cada uez ssej mais pouco- he mũy scura, peçouos, pois me nom posso teer de amar, que em este caso me dees sãao consselho e me enssynees finalmente o que me he mjlhor e mais sãao de fazer.

Confessor: Filho meu, leixando todallas trufas aa de parte, eu por teu amor te quero ora dizer toda a uerdade.

\section{[EPÍLOGO]}

[Capítulo XXIX] Acabada a confissõ, o Confessor Genius deu sãao consselho ao Amante segundo a ele era mais conpridoiro.

[Q]uanto mais alto he o negoçio tanto mais neçessario he ao negoçiador de sseer sotill em seu feito. Porem, filho meu, eu entendo bẽ o que em esta tua confissom me as dito e esso meesmo rrogado, e, finalmente, por consselho deste teu negoçio en que es posto, eu cujdo datar o teu feito onde ora elle sta desatado e des hi fazer fym deste nosso rrazoamento. Ca no começo desta tua [18rb] confissom te promety que, nom enbargando que eu chegado fosse aa dessa Venus, que por onrra de mjnha ordẽ saçerdotal eu de meu ofiçio te ensynaria tal doctrina polla qual te ouuesses denclinar mais aas uertudes que aos biçios. Porende, fallando mais adiante em ffeito deste teu amor, consselhote que o enpregues en llogar onde te possa prestar. Ca este amor en que tu ora stas, segundo eu ueio per teu rrazoar, elle he pecado, e pecado nom pode merçer prez de serujr nem louuor ou prez, e quem sse trabalha de serujr sem louuor ou prez nõ ssej que proueito possa ende rrecobrar. Assy que, sse tu enpregares o trabalho por cousa de que a ty nom pode bỹr proueito nem louuor, contra ty medes nom husas de boo rrecado, ca, posto que ouuesses logar de conprir teu delleytamento, bem sabes que aa fym todo he pena e pena he mujto pera squiuar. Porem de marauylhar he que tal cousa pollos homẽes que ssom rrazoauees seia deseiada, porque ueemos cada dia a olho en como quâto mais o çepo he queimado tanto mais asynha he tornado em çynsa. E esso meesmo que pollo enpeçar do pee o homẽ muytas uezes bay dar cõ a cabeça no chãao. Per esto consyra na tua bõtade en como Amor he çego: ataa [18va] que caya nõ conheçee o camynho en que anda. Porem, se per boo consselho nõ for gujado, quem em el caae auera rrezom de sse temer. Mas boo consselho trespassa todallas outras cousas, speçialmente naquel que entende de sseer rrej. Assi como de todollos homẽes, geeralmente cada hũu em seu cabo tem de julgar hũu rregno, scilicet se el mal rreger o rregno de sseu juizo sera aazo de perder ssy medes. Ca aquel que nom ha poder sobre ssy meesmo as pedras preçiosas e as cascas dos berguegões todas a elle stam em hũu uallor, porque, ajnda que teuesse o mũdo a sseu mãdado, tanto que nom quer guardar seu coraçõ e o gujar como deue, engana ssy medes e quãto faz tudo he uãao. 
Por esto, filho meu, o que te ante disse agora aynda to rrecõto outra uez, que te leuantes ante que cayas, per tal guisa que nom possas rreleuar te medes quãdo quiseres. Ca Amor, que senpre foy çego, faz çegos todos aquelles que o seruem; e se tu ante desto steueste em este caso tenpo he que te rretenhas dello quãto poderes e de ssometer o teu coraçom so aquela ley que per rrazõ he gouernada e nõ per uoontade.

E por enssynança de esto que te ora digo assaz de enxenplos te hey contados, pollos quaees tu podes entender como toda delleitaçom nõ dura senom pouco. Ora, filho meu, [18vb] parte do que te queria dar a entender creo que tees conçebido na tua uontade, e se tu creeres a mjnha doctrina ou nom daqui en diante pareçera e sera sabudo, ca eu nõ te posso mais fazer saluo enssynarte o camjnho dereito. Ora en ty seia a escolheita, se quiseres biuer ou morrer.

[Capítulo XXX] Aqui falla das departiçõoes que o Confessor e o Amante ouuerom antre ssy em fym da confissom.

[P]adre meu, pois assy he que eu ja ouuy a uossa storia, aa qual se uos nõ desse rreposta eu ficaria em grande culpa, as mynhas penas e o noio que padeço a uos he jogo, que nom auees sentimento do que eu sento. $\mathrm{Ca}$ a door do calcanhar nõ he semelhauel aa do coraçom, a qual eu nom posso tirar de mỹ aynda que queira, assi como uos podees, que staaes quite das penas damor, de que me eu tanto querello. $O$ çeruo que no mato anda solto pera õde se paga sabe mũỹ pouco <quena> [que pena] padeçe o boy que anda tirando o arado. E bem asi aconteçe aas uezes a muytos homẽes, que em uẽedo padeçer outros se maraujlhã; mas, se elles sentyssẽ e soubessẽ a uerdade das penas suas, eles fariã o que os outros fazem, ou pyor mujto asynha. Porque eu ssej mũỹ bem, e assi o ssabees uos, que amor he hũa cousa que senpre foy... [19ra, rb, va, vb]

$\left[\right.$ Lacuna $^{43}:$...vsada entre los onbres e las mugeres. Por agora, con esto me escuso. Mas, padre mjo, sy vos agora en esta mj querella conta Cupido e Benus me querés tanto ayudar, porque mj coraçón de padeçer de algún tuerto podiese ser aljuyado, faríadesme muy grande bien. Ca yo sé que para mj provecho nunca otro tal clérigo en el mundo fue nasçido commo vos. Ca, en quanto yo estó commo sobre cosa no çierta, sabiendo sy es a mý ordenado plazer o enojo, padesco dentro en mi corazón grant mjedo, en tanto que non sé qué será de mj njn qué consejo me tome. Mas por fynal conclusyón de todo mj fecho en palabras llanas entyendo de escreujr vna supljcaçión para Benus, la diesa, la qual, padre mjo, yo vos rruego que le vos queráys presentar e traerme dello buena rrepuesta.

E estonçes entre mj el my clérigo ovo vna habla de grant posybylidat e muy prolixa. Ca, no enbargante que mj rrazón no entendiese bien, lo que me él

${ }^{43}$ Los Capítulos XXX (restante) y XXXI, es decir capítulos XXXI y XXXII castellanos [CCCL y CCCLI])]-, no están encuadernados con el libro VIII en el ms. de Palacio: «Departiçõoes que o Confessor e o Amante ouuerom antre ssy»; "Que trata de la carta o suplicaçión que Benus, de partes del Amante, rreçibió por Genjus, su clérigo» y en apariencia se han perdido. Lo que sigue es el texto castellano, tomado de Alvar, con las modificaciones editoriales ya señaladas arriba. 
consejaua todo hera verdad por mj grant bien. Pero la mj voluntad del su rrazonar fizo pequenna cuenta, porque en cosa de tamanno seso al que con rrazón es afyncado, viénele dello poco plazer njn folgança. Porque, donde Amor es sennor del coraçón del onbre e rrazón no á lugar en él, commo cosas muy contrarias que no tienden a vn fn. Asý que, sobre aquesto, yo e mj clérigo estamos desabenydos. Mas yo, de mj cabo, so tal mesura rrazoné mjs palabras que quedamos concordes. Et él me prometió que fablaría a Benus por mj, et, asý mesmo, a Cupido, dizyéndome que ecriuujese lo que quysyese et que él, lealmente, lo diría al dios de Amor. Asentéme estonçes sobre las yeruas verdes, estando lleno de fantasýas de Amor. En lugar de tynta, con lágrimas de mjs ojos començé de escreujr vna carta en esta guysa»:

[Capítulo XXI] Que trata de la carta o suplicaçión que Benus, de partes del Amante, rreçibió por Genjus, su clérigo.

[L] a dolorida pena de la enfermedat de Amor, contra la qual njnguna física puede ayudar njn aprovechar, con enbeueçimyento tiene enpachado el mj coraçón. E, en tal guysa que agora travaje o tome folgança, yo lo fallo syenpre presto a conbatr mj rrazón, que dél non me sé defender. Por ende, querría yo buscar melezjna con que me pudiese rremediar, non sé en qué manera. Ca, sy me quexare a dios de la natura, fallo que algunas criaturas, algunt tiempo del anno, tienen Amor en su poder, e en tanto que, desde el más pequenno coraçón, segunt la medida de su naturaleza, tiene su cargo. Mas yo, que no deseo syno sola vna, la qual es apartada de mj, commo de onbre de que faze pequenno cuydado, asy que todas las criaturas algún plazer an en Amor. E, porque la rrazón del mj entendimjento non puede conçebjr el modo en que la naturaleza me manda amar, no me ponyendo determynaçión çierta, sy tengo de rrecabdar o no, por ende, seyendo o puesto en estos dos estremos, commo aquel que non sabe sy ha de morir o de beuyr. Et, avnque razón pelee con mj voluntad, no puedo ser apartado de amar. Asy que sobre mj es complida aquella estoria que dize en cómmo dios de la naturaleza, que es Pan, luchó con el Amor. Ca yo syenpre quedo vençido, en tal guysa que, en mj coraçón, no fallo fuerça poque sola vna hora pueda estar en pie, aquesto es porque mj entendimjento con Amor es todo derribado. Quien menester á ayuda, conviene que la demande o que, por mengua de su sý, pierda todo en su negoçio. Et commo quier que yo todos mjs entendimjentos aya buscado, njnguno non me sabe ayudar, según que mj voluntad desea, pues que demande ayuda a my sennora bien sé que me aprouechará poco. Et, por ende, non fallo camyno cómmo pueda ser ayudado. Et avnque al gran Júpiter demando ayuda e le rruego que quiera prestar de su graçia, dándome a beuer de aquel tonel, que en su bodega tiene ençerrado, de beuer dulçe; pues que yo tanto he padeçido, bien çierto so que aquella tal fortuna es de mj bien apartada, mas del beuer amargoso yo bien çierto puedo fazer testimonyo, commo aquel que muchas vezes lo ha prouado. Asý que esto que padesco no es por juego, pues que yo syenpre demando de beuer $e$ syenpre me dan lo amargo a beuer. Yo veo este mundo estar sobre mudança, vnas vezes en calma e otras vezes en tenpestad, et otras vezes tiempos tenprados, et otras, calurosos. Et veo, otrosý, que la luna cada día se muda et que todas las cosas se mudan. Et las graues e las crudas muchas vezes se tornan en paz, mas el no querer syenpre está contra mj en vn estado. Ca, por me fazer graçia, sola vna 
ora no quiere mudar su voluntad. Ovidio, el grant clérigo, sobre esta materia cuenta en cómmo el dios que de Amor tiene la governança es llamado Cupido, el qual, según él dize, con... $]^{44}$

... [20ra] dardos queymantes que tem em as mãaos, muytas uexes fere en lugar onde nom cujda de ssaar. E esto ẽ parte he causa da mjnha querella. Diz ajn-

44 Será importante para la comprensión final del libro recordar que, en el libro V, se había ya hecho, al hablar de los dioses de los gentiles, un tratamiento extenso y nada halagüeño de Venus y Cupido (caps. CXXXII, CXXXIII y CXXXIV del texto castellano) (cf. asimismo con la glosa del dios Cupido infra):

Amante: «Padre meu, assy pareçe a mỹ, mais hũa cousa uos peço aynda mays que me queyrades declarar, de como o deus e a deessa do Amor, de que todo o mũdo falla, cobrarom e ouuerõ os seus primeiros nomes, por quãto uos ataaqui do sseu stado nehũa cousa ẽmentastes».

[O] Confessor falla aqui de Uenus, que he chamada deessa do Amor.

«[F]ilho meu, porque eu soo seu clerigo leixey de fallar delles por uergonha. Mas por quanto a materia desta tua confissom sta principalmente sobre elles, porem para bem mentes ca eu de todo te cuydo dizer a uerdade. Venus foy filha de dom Sotumo, e era de tal condiçom que todo daũger ẽ amor lãçaua a de parte soomente por segujr seu tallante, de tall guysa que em qualquer logar que steuessẽ homẽes acharom senpre em ella graça. E em usando esta tallantosa ujda ouue filhos de desuayrados homẽes, asi como Mares, que ouue della hũa filha chamada Armena. Della proçedeu outrossy Andragena, cuio padre foy Mercurio. E ella de Anchises foy madre, o qual era filho de Eneas de Troya. E Uerycom foy seu filho outrossy, cujo padre Bytem ouue nome. E quãdo byo que hi nõ auya mais deytousse cõ Jupyter, seu jrmãao, e ouue dele hũu filho chamado Cupido, que de rrostro era mũy fremoso. Mas tanto que este seu filho chegou a ydade dhomẽ acertousse hũa ora que byu sua madre amorosa, e elle, que de sua naturalleza era luxurioso e nõ tynholhos con que ueer rrazõ algũa, tanto que sse byo cõ sua madre chegousse a ella e beyiouha. $E$ ella, que outro sentydo nõ auya saluo o que a luxuria perteçee, tomouho por seu namorado, de tal guisa que anbos ficarõ çegos. E assy, porque Cupido ousou damar sua madre, este nome de deus dAmor lhe ffoy aposto. Entom Venus, outrossy pẽsando de continuar seus delleytamentos, muytos outros namorados ouue, aallem deste que dictos hey. E por se scusar aynda mjlhor da sua maa usança fez aquelle iogo seer comũu a todas. E pos por lley que toda molher podesse tomar qualquer homẽ que lhe caysse em uoontade e nõ leixar porem de sseer comũu a todo tẽpo que ella quisesse. Esta Uenus foy a primeira outrossy que disse aas molheres que uendessẽ seus corpos, e, segundo se acha ẽ scripto, Semyramus della tomou aquella enpresa. E assy a fremosa Neabolla $<\mathrm{ffez}\rangle$, natural de Rroma, ffez semelhauelmente como aquella, que con todo homẽ era conpanheira, nõ doujdando o sseu corpo a quẽ o quisesse. [...] Ves aqui hũa lixosa e desuyada creença que os gregos entõ tynhã, ca, ao tenpo que Uenus assy este nome tomou de sseer chamada deessa, nõ auya cousa a sso a llũa per que a elles biesse bem ou mal que naquelle caso nom tomassẽ hũu deus ou deessa por sua ajuda».

Nota da Epistolla que Dydemo, rey de Draginus, screueo a El-Rrey Allexandre o Grãde ẽ rrazõ dos muytos deuses que os gregos adorauõ.

«[E]m testemunho que esto ffoy uerdade eu acho El-Rrey de Dra[g]inus, que Dydamo era chamado, em hũa epistolla que screueo a El-Rrey Alexandre por despreçamento da fe que os gregos entom mantynham, disse que por cada hũu menbro que o homẽ no corpo [tynha], os gregos ẽ spiçial hũu deus tynhã apropriado, o qual elle seus braços stendiam e ao tenpo de sseu mester demandauã sua ajuda. A Mynerua, que era sesuda, rrogarõ elles por a cabeça, porque o ent $<i>$ [en]dimento e a rrazõ que homẽ ha ẽ as çellulas do myollo som ençarrados, de que segundo elles afirmarõ ella sobre todos ouue melhoria. Mercurio ẽ sseus dias de falssas lleis era gram pronũz̧iador, e porem, quãdo elles auyam de fallar a elle, das suas lyngoas dauã a encomenda. E porque Bacus era guargantõ, elles o adorauõ polla guarganta, por tal que com os doçes beueres lauasse ameude suas guargantas. Dos onbros e dos braços Hercolles foy auudo por deus, porque elle ẽ feyto darmas era o mais poderoso, e porem todollos menbros a elle encomẽdarõ. $\mathrm{O}$ deus que foy chamado Mars do coraçom e 
da mais, que o conprimento deste amor sta en poder da deessa Venus, a qual a nehũu pode fazer graça ao tenpo que toma consselho com Saturno, ẽ no qual tenpo, segundo eu acho e entendo, foy começado o amor de que proçede este meu nojo. E por ende eu nom sey que consselho tome, saluo cõ todo obedicymento do meu coraçõ rrogo a uos, Cupido e Venus, que, sse ao tenpo que eu primeiramente começey damar fostes sanhudos em algũa parte, que uos aquella sanha e jnfortuna queyraaes lançar a llonge, en tal guisa que Dãũger -que com mjnha senhor ataaquy foy rrethudo - seia de todo en todo rremouydo de sseu logar. Oo tu, Cupido, que com o teu dardo queyma[ ]te tees açeso meu coraçom, ordena maneira en como da ferida que me deste eu seia sãao per aquella meezinha que deseio, ca seruj̧̧o em a tua corte sem soldada a mỹ, [que] senpre ataqui guardey os teus mandados aa lley do Amor, nũca pode seer onesto! Oo gentyl Venus, que es rraynha dAmor, sem o mereçendo eu tu tomas de mỹ byngança, em fazẽdo seer a mjnha pena senpre uerde por amor, o qual ataaquy nũca mynha ffortuna quis que eu cobrasse! [20rb] Porem, por conclusom de todo esto que eu deseio, rrogote que do meu amor me des guallardom segundo eu mereço, ou me faças logo dar morte queienda por bem teueres ${ }^{45}$.

\section{[Capítulo XXXII] En como Venus rrespondeu a cada hüa das cousas cont- heudas na suplicaçom do Amante.}

[A]cabada descreuer esta mynha suplicaçom pollo modo que uos eu hey rrazoado, Genyus, o meu confessor, açeytouha logo da mjnha mãao, como aquelle que queria tomar encarrego pera a presentar a Venus e Cupido da mjnha parte. $\mathrm{E}$, ficando eu em aquel lugar onde me el confessara primeiro, se foy dereito a Venus por saber queiãda era sua uoontade. E nõ tardou alla o terço dhũa ora que, em oolhando eu scontra hũa parte da mata, by subitamente Venus star açerca de mỹ a sso hũa aruor uerde. Pugeme entõ en giolhos ante ella, pedindolhe por merçee que ouuesse de mỹ conpaxõ e piedade. E ella, em oolhando mẽtes ao meu rrostro, em modo de joguetar preguntou por meu nome. «Senhora», disse eu, «a mỹ chamam Joham Goer». «Joham», disse ella, «en rrazom do teu amor a ty conuem destar per fforça so o meu poder. E sabe que eu bem entendo a tua petiçom en que primeiramente te querellas a dom Cupido, meu filho, e a mỹ, e esso meesmo aa Naturalleza. Mas com esso nom [20va] tenho eu que fazer, porque he cousa que em sollido he antre ty e ella, ca a Naturalleza he dado o

dos peytos auya a guarda, ao qual elles muyto rrogarõ que elle os seus coraçõoes quisesse esfforçar. E pollo fell adorarõ elles a deessa Juno, porque em manãcoria ella foy mũỹ arreuatada. Cupido, que tem o tiçom do fogo, per que as uoontades en prazer som acreçentadas, elle do stamago, que senpre fferue, foy entõ auudo por prinçipal senhor. A deessa Çeres, porque do pam foy acrecentadeyra, 0 encarrego do uentre lhe foy encomendado. E aa deessa Uenus, que por sua luxuria era deyficada, elle teue a guarda de todo o al que a aquelle mester he apropriado».

${ }^{45}$ Para completar el cuadro de las descripciones de Amor, recuérdense éstas del libro VII.

Do terçeiro syno, que he Geminy.

"[O] terçeiro syno he chamado Geminy e este he figurado semelhante a dos gemeos nuus, cuia cabeça tem parte daquellas duas strellas luzentes que no cabo do Touro som asseentadas, mas o sseu uentre tẽ çinquo e os seus pees duas, e, segundo diz Thollomeu nos seus liuros, o mes que he apropriado a este syno he o tallãtoso mayo, quãdo todallas aues ẽ suas uozes sobre os rramos uerdes andã cantando e Amor, segundo a lley de naturalleza, pũge a mançebya de cada hũa creatura». 
assenhoramento de todallas criaturas uyuas, saluo quãdo assy aconteçe que ella acha algũu homẽ de boa uyda que contra a ssua ley queira rresistyr aos apetytos delleytosos, o que ao tenpo dora mũỹ poucas uezes se açerta antre os homẽes. Mas assaz ha hi doutros que de sseu maao rrecado contra o ofiçio da Naturalleza se delleitam em desuayrados viçios, de que ella muytas uezes se querella. E esso meesmo a mynha corte fica descontẽta, como aquella que de maamente rreçebe estes taaes que Naturalleza assy engana. Porque a mjnha corte se rrege soomente per gentyl amor e nõ sse contenta saluo de cousa que a Naturalleza seia deuuda, de que eu a ty nom ponho culpa, porque muyto tenpo ha que tu es rrethudo por hũu dos da mjnha corte; polla qual cousa eu som tehuda dauer conpaxõ do teu noio e de rremouer aquella ynffortuna que tãtos dias ha que te tem agrauado. E sse o meu consselho for creudo, ante que daqui partas tu seras alyuado daquel praziuel noio sem saude con que tu dizes que o teu coraçom he agora açeso. Mas quãto monta ao que deseias, segundo no teu scripto faz mẽçõ, a ty conpre todauya fazer em ello como te eu diser, porque, tanto que tu [20vb] fores sãao, a ty abastara hũa meezinha que eu tenho, a qual pera os doentes he mũỹ boa. E aynda que ella tal nom seia como tu per uẽtura querias, pero ella sera queienda a naturalleza dAmor segundo Rrazõ deue sseer concordante. Ca no stado ẽ que te tu ora acho, a ty per os da mynha corte sera dado o teu guallardom. E se mais quyseres nom he rrazom que o ajas».

[Capítulo XXXIII] Aqui, ueendo Venus en como o Amante era uelho e fraco, repreendeu per desuayrados modos a ssua nom abastança.

[V]enus, cuja ley sta sobre cousa nom çerta, assi como he o iogo das sortes en que os homẽes açertam suas auenturas, nõ põe mais peso na ballança se nom quanto a ella apraz que seia pesado. Ca aquel que uerdadeiramente ama ela muytas uezes o llança fora e asseenta em seu lugar o deslleal que usa dengano e de falssura. Assy que, segundo a mỹ pareçe, ella nas causas dAmor julga este mũdo çegamente. E, posto que eu nõ sayba o que os outros de ssy dizem, eu bem sẽto de meu cabo que som lançado fora da sua graça, como aquella que do meu amor tem çercada a fym a que me hej de teer. E desto nõ me conprem outras testemunhas senom mỹ [21ra] medes. Ca, tanto que esta deessa Venus parou mentes ao meu rrostro, por maneira descarnho disse em esta guisa:

«Tu bem sabes que eu ssõ aquella Venus que busco soomente os meus delleytos per onde eu posso. E, aỹda que te trabalhes de guãaçar meu amor, eu sõo bem çerta que em tua pessoa poucos delleitos acharey, porque delleitaçom em amor e cabellos cãaos em camara onde meu prazer he husado som mũỹ pouco concordantes $^{46}$. E, posto que tu des a entender aa de ffora que tees coraçom

${ }^{46}$ El tema de la concordancia (o falta de ella) entre Amor y Vejez es ya tópico en la literatua clásica, ya sea a favor (Anacreonte), ya sea en contra (Marcial). Para la literatura medieval, frente a la visión idealizada de la vejez del diálogo homónimo de Cicerón, debe resaltarse la sátira realista de Boncompagno, tanto en su Rota Veneris como en De senectute. Ver Cortijo \& Blecua para más detalles. $C f$. la burla sobre el marido viejo a modo de ejemplo (Rota Veneris, cap. VIII):

Disuasión contra [tomar] marido por razón de su vejez. 
dhomẽ nouo pollo teu doayro bem se mostra en como uelho rruço nom he poldro. Ca antre ty e os outros muytos que ja teendes muytos anos furtados, em fyngẽdo aa de fora que sodes homẽes nouos, ao tenpo da proua, fallãdo uerdade, nõ leixaaes porem de sseer mjguados e fracos. Porque dhũa cousa sey çerto, que os que queriam e nõ podem ao tenpo dagora nõ som amados; e po$\mathrm{rem}$, ante que tu em amor faças taaes prouas queiendas tu entendes que nom podes acabar, mjlhor te sera no começo de fazer hũu fermoso rreteer. $\mathrm{Ca}$, posto que tu podesses chegar ao teu amor, se te ssentes nom abastante pera conprir o que a amor perteeçe, nõ te seguyra ende senom hũu padeçimento [21rb] sem proueito. Por ende rrecolhe a ty medes o teu coraçom outra uez, por tal que por aazo do teu trabalho bãao $\mathrm{a}^{47}$ mjnha corte nõ ffique ẽganada. Ca, aynda que eu seia çerta que a tua uoontade he assaz boa, al conpre ao arado, de que tu es bem mỹguado, segundo eu entendo. Assy que, ante que começes cousa que nom possas bẽ acabar, a ti conpre dauer conheçimento do fraco stado en que es posto, por tal que nom seias semelhante ao homẽ que sse trabalha de tractar mercadaria e nom tẽ con que a pagar. Filho meu, se tu quiseres bem parar mentes a esto que eu agora rrazoo, todo perteeçe a ty tanto como a nehũu outro homẽ e sey nenbrado que o teu feito he agora tornado em foy, bem como a herua que sse torna em feno seco. Porem, $\mathrm{meu}^{48}$ consselho he que te nẽbre todauja en como tu es uelho e que do poder que sohias auer es agora mũ̃y fallydo».

[Capítulo XXXIV] [A]qui diz en como Amante, seendo mũ̃̃ triste por o que lhe disera Venus, cahyu en terra assy como morto, onde Cupido cõ muytas conpanhas de namorados lhe apareçeo em bisom.

[T] anto que Venus teue acabada sua storia ${ }^{49}$, eu de meu cabo dentro em mỹ rreuoluy todos meus entendimentos. E, quãdo soube de çerto que nom auya hi camynho pera cobrar o que eu deseiaua, assy como [21 va] hũu homẽ que com auga fria apaga a labareda do fogo, assy me aconteçeo logo em aquella ora. Ca, por o noio que o meu coraçom entom tomaua, hũu frio me arrebatou subitamente, en tal guisa que com rrostro amarello e descoorado cahi smoreçido en terra. E em jazendo assy, nõ bem byuo nem de todo morto, pareçeome que per ante meus olhos by <by> bĩr Cupido com seu arco armado nas mãaos; e, assy como a hũas cortes que pera este feito açỹte fossẽ feitas, com el bynha em con-

¡Locura inaudita! ¡Estupidez digna sólo de mujer! ¡Cómo pudiste dar oídos o siquiera concebir la idea de unirte a un hombre tal, consumido ya por la debilidad senil, con cataratas, que cuando bebe no dejan de caérsele, una a una, las lágrimas que constantemente segregan sus ojos en el vaso de vino, donde también se le queda la baba al beber, y que cuando come gargajea, y eructa y le salen de la nariz constantemente mucosidades que se limpia con el mantel. Además de esto, cuando se va a dormir, ronca, lanza ventosidades y se tira los más fétidos pedos. [...] Éste os dará un beso con boca desdentada, pero al menos tendrá la humedas de sus encías pútridas. Por añadidura, viejos así suelen siempre pecar de celos y constantemente sospechan malicia en sus mujeres, así que aunque sean inocentes no dejarán de quedar bajo sospecha. Por si fuera poco tendrás hijastros e hijastras que te maltratarán, pues raro es que haya concordia entre hijastros y madrastras.

47 'a': 'a a', 'a' tachada'.

48 'meu': 'nt meu', 'nt' tachado.

49 'storia': 'confissom storia', 'confissom' tachado. 
panhias departidas todo o mũdo de gentys homẽes que em seu tenpo forom namorados. E des hi, en parãdo mentes arredor aos hũus e aos outros, by tallantosa mãçebia, como capitam de gentes mũỹ apostas, star ante os seus em aquel chãao, os quaees com cabelos penteados tynham en çima das cabeças chapelletas nom todas dhũa collor, ca dellas eram de folha e dellas de frol e outras dalioffar bem graado. Ally by ẽtom a guisa noua de Boemya cõ desuayradas obras mũy bem deuysadas. Assy que todo eram delleytos en que elles andauam, en tanto que nom auya hi cantar que a amor perteeçesse que eu entõ mũỹ bem nõ scujtasse. Ca os delleytamentos da mellodia que ueem de [21 vb] tanger de pipas e doutros stormẽtos de musyca forom entom aly ouuydos tam altamente, que pareçia que todo o çeeo de çyma em sõo de concordança daltas pipas rressoada, que de ouuyr era assy como hũu parayso. E com esso, por acreçentamento do sseu amor, segundo o mãdado da tallantosa mançebia, byos dançar e saltar mũỹ frescamente. Assy que assaz auya hi de prazer e sollaz, como aquelles que por lançar de ssy todo noio e cujdado rryam e joguetauõ, tomãdo <tomando> todo sabor que podiã. E aallem desto a mayor parte dos que fallauom, segundo eu entendy, foy de feito darmas e caualaria, e que cousa he de jazer em braços ao tenpo que o homẽ tem cobrado seu amor.

[Capítulo XXXV] Dos nomes daquelles que em outro tenpo forom namorados, assy uelhos como mançebos, que apareçeró ao Amante jazendo smoreçido.

[A]lly by eu Tristam e a fermosa Jsolda, Lançarot e Gymor, Gallaot cõ sua senhor, Jaasom com sua namorada Creusa. E esso meesmo Hercolles $\mathrm{o}^{50}$ forte, $\mathrm{o}$ qual ffez toda sua dilligęçia por fazer prazer a Eollem, a que el mũỹ grande bem queria. Teseeus, [22ra] aynda que a Amor nom fosse uerdadeyro, hi staua entom cõ Phedra, que el scolheo por sua namorada. De Greçia outrossy hi pareçeo rey Thallamõ, que per fforça cobrou em seu poder Esyona, filha dEl-Rrey Leomedom de Troya, ao tenpo que Jaasom depois da bynda de Colcos pollo primeiro odio tomou byngança sobre ella, a qual tomada foy aazo da desauẽeça que foy antre os gregos e os troyãaos quãdo aquella çidade per El-Rrey Priamo foy outra uez rrenouada. Em bisom a mỹ pareçeo outrossy que by Ector com Pantasillea e Parys com Ellena, sua mũỹ bem querida. Troyllus com Cresayda staua hi tam bem, mas antre os jogos que el fazia mostraua aas uezes senbrante pesado, como aquel que antes ouuyra dizer que Diomedes demandaua de sseer seu parçeiro. Mais de myl, afora este que dicto hey, bi star en conpanha de mãçebia mũỹ apostados, e cada hũu com sua namorada chea de prazer e dallegria. Outros by que sse querelauam muyto ameude, antre os quaees Narçyso foy hũu e Pyramo outro, que stauam mũỹ anoiados, e com elles Achilles, Agamenõ e Menallao e outros muytos que nas causas damor sentyrom suas fortunas mũy contrairas.

[22rb] De molheres que stauom ẽ aquel medes caso eu by Dydo, que Enea leixou, e Philles, que Demophom enganou, e Adriana, que fez mũỹ grande doo porque Teseus por Phedra, sua jrmãa, como homẽ desconheçido a desenparou. E

50 'o': ‘cõ o', ‘cõ' tachado. 
antre as outras que hi stauam eu by querellar de Hercolles aquella sua primeira namorada, Dyamyra, per cuio aazo em a fỹ de sseus dias elle em fogo foy queymado. Medea outrossy staua hi, querellandosse de Jaasom por quãto el ssem por que a lleixara e foy tomar outra de nouo, por a qual cousa ella en presença de todos dizia ameude «Fym por todollos uerdadeiros». Vy outrossy aquella Deyamya que Achilles desenparou quãndo Diomedes per mandado dos gregos que jaziam sobre Troya por el ffoy. Antre as outras muytas que hi stauom sobre o prado uerde uy aquella doorida rraynha Cleopatla que por amor de Antonyo, seu bem querido, em hũa coua chea de serpẽtes se ssoterrou byua. E com ella tãbẽ by star Tysbee, a qual por amor de Piramo sobre a ponta dhũa spada em forte ponto padeçeo morte, e, segundo per suas pallauras pude entẽder, ella oraua muyto mal a todollos pregujçosos. Phillomena e Progna by eu ally fazer grãde [22va] querella polla maa uerdade de Thereus, per que ellas anbas na fym $<$ per que ellas anbas na fym $>$ de todo en todo forom desffeytas. Açerca destas vy eu star aquella molher Canaça, que, por amor de Machayro, perdeo a graça de sseu padre e en cabo morreo em forte ponto. $E$ antre as outras que eu lla by no meu scripto foy Polliçena, a filha dEl-Rrey Priamo, que Pyrus matou, a qual staua fazendo mũỹ grande doo por quãto ella — sem mereçendo mortemorreo por amor, aynda que nom teuesse namorado.

Mas fallando dalgũas outras que sse contentauam do desporto que proçede doutra condiçom, eu by Cyrçes e Calypsa, as quaees per arte magyca e feytiçaria que sabiam fizerom aas uezes eclyusar a llũa e mudar as semelhanças dos homẽes $\tilde{e}$ qualquer figura que elles queriam, por tal de os teer em seu poder e fazer o que a amor perteeçe, aynda que nom quisessẽ. Antre as outras molheres by quatro cuja nomeada sobre todas quãtas na corte syam era muyto louuada, aas quaees todos geeralmente faziam rreuerença, assy como se fossem deessas uerdadeiras ou de todo o mũdo enpatrizes. E em scujtando o que dellas diziam por seu louuor ouuy dizer [22vb] estas pallauras: «Vos sodes aquellas quatro cuja lealdade na ley do casamento foy mũ̃y bem prouada em uossa ujda, e, porem, por enxenplo de todallas casadas que boas querem seer, Fama, que os grandes feytos nõ quer asconder, em cronyca outentyca aynda publica sua nomeada». A primeira foy chamada Penalope, a qual em amor de muytos caualleiros e senhores foy cometida, jazendo El-Rrey Vllixes, seu marido e senhor, per spaço de mujtos anos em çerco sobre a grande Troya. Mas ella, como molher que todo prazer tynha posto em seu marido, soomente de tal guisa guardou sua õrra enquãto el staua fora da terra, que todo o mũdo, spiçialmente os de Greçia, notarom seu feito por de grande bondade. A outra foy Lucreçia, molher de Collatyno de Rroma, a qual, seendo costrãgida per Tarquino pera fazer cousa contra sua uoontade, soomente por temor de uergonha e guarda de sua boa nomeada, como hũa das mjlhores molheres do que no mundo ouue, scolheo de morrer. A terçeira foy chamada Alçesta, que rrogou aos deuses que tirassem a enfirmjdade da morte de sseu marido e a dessẽ a ella, polla qual ella morreo. [23ra] Veede ora se esta era boa molher. A quarta molher que eu alla by foy Alçyona, segundo ouuy dizer a aquelles que stauam açerca de mỹ, a qual guardou senpre seu corpo mũỹ lealmente a Scix, seu senhor e marido, e en tanto que, quãdo ella o uyo allagado no mar, saltou fora e começou a nadar sobre as uagas ataa que prouue aos deuses de a tornar em aue, que pollo grande amor que lhe auja com suas aas o andaua abraçãdo. 
Estas forom aquellas quatro molheres stremadas que eu alla by, que sobre todas ouuerom Amor mais en gouernança. Mas por quãto Mãçebia, que da corte dAmor he marischal, era occupado ${ }^{51}$ nas cousas que a el tangiam, nõ curou de oolhar pera mỹ onde eu jazia. Entom parey mentes e by en como Velhiçe uynha seu passo a passo pera onde staua Venus, tragendo conssigo mũỹ grande conpanha, mas nom tamanha como Mãçebia. E a mayor parte que com ela bynha era de grande hidade, segundo se mostrou pollo senbrante de cada hũu delles. Pero nom leixarõ por ende de fazer quãto podiam por pareçerem homẽes nouos aa bista da gente. Mas dhũa cousa eu fuy [23rb] perçebido, que oolhey e nom by outras pipas senom doçaynas, com arpa, laude e çitolla, que pera os homẽes uelhos som boas porque soam baixo. Assy que ao sõo daquelles stormentos elles mũỹ passamente dançarõ a baixa dança e cantarom em carrolla, segundo Amor os costrangia. E aas uezes ryam mesuradamente cõ as molheres; mas o sseu rjso nõ era tam alto como o dos mançebos. Pero by per suas contenenças que elles bem en ssy andauõ alterados per aazo do Amor, de que proçedia todo seu prazer. Antre os outros que hi stauam a mỹ pareçeo que by El-Rrey Dauyd com sua amiga Bresabea, e Ssallamõ nom staua sem conpanhia, ca antre molheres reçebidas e mançebas das dos gentios e de judias tynha hi mais de çento em hũu rrenque. Nom sey eu se elle era abastante pera tãtas, mas esto sey, que, nom enbargando o sseu grande siso, elle era preso per aquelle aluara que Amor aas uezes asseella per suas mãaos, do qual nehũu homẽ terreal ha poder de apellar. Aallem desto aynda eu ally conheçy Sanssom e sua amiga Dallyda, por cujo amor sua força foy de todo derribada. Outrossy eu by star antre os outros [23va] aquel phillosopho Aristotilles, que a rraynha de Greçia enfreou com suas mãaos, ao qual ella naquelle tenpo fez tal syllogismo, que, nom enbargando a ssua logica ou outra arte que el soubesse praticar, nõ sse soube deffender por entom que nom fosse concludido pera serujr a Amor. Vyrgillyo vy, e com el Ssortes e Platom e o poeta Ouuidyo. Entõ penssey dentro em mỹ en como Amor he mujto doçe, pois sabia amãssar taaes sabedores como estes. E no ponto en que eu staua tyue ẽ mỹ mais pequena uergonha de perder ou de guançar. E por este modo leixeyme jazer sperando por graça, tanto que estes forom chegados ao lugar onde Venus staua e me byrom jazer en terra. Todos os uelhos a hũa uoz rrogarom aa dessa que ouuesse comigo conpaixõ, e ella, que nom podia contradizer, leixou piedade entrar $\mathrm{p}[\mathrm{o}]$ llas suas orelhas e rrogou a Cupido, seu filho, que da sua graça me quisesse confortar, per que ao caso que me era aconteçido eu podesse auer algũu rrelleuamento. Per esta guisa os antigos que hi stauam rrogarom por mỹ e diserom que era dauer [23vb] piedade, porque per mj̃gua dacorrimento jazia padeçendo forte ujda.

[Capítulo XXXVI] Aqui tracta en como Cupido tirou do Amante o dardo açendido cõ que o dantes ferira e Uenus, uẽedoo velho e sem queentura natural, tirada a doudyçe do seu amor, fezeo rrestetuyr a ssãao entendimento rrazoauel.

[C] upido, que nas causas dAmor tem o poder de feryr e saar, por mjnha saude e polla dos outros que lhe auyã rrogado veo cõ sua madre Venus, fazendo anbos hũu sõo, per ssobre hũas heruas uerdes, ataa que chegarõ onde eu jazia

51 'occupado': 'occupadado', '-da-' tachado. 
deytado. E logo em hũu põto hi ouue tam grande pressa de taaes namorados queiandos eu antes disse, que o numero delles a meu pareçer nõ ha homẽ que os podesse contar em çerto. Mas a mayor parte que hi bynha erã uelhos, que deseiauom de beer a fym do que me auya daconteçer em feito da cura de mjnha doudiçe. Entom forom começados antre elles grandes departiçõoes, dizẽdo cada hũu o que lhe pareçia segundo seu juizo. Mas enpero, antre as outras cousas, bem entendy que elles auyam pesar pollo meu, porque eu lhes ouuy dizer que nehũu homẽ [24ra] velho deuya dendoudeçer por rryorta, pois em el nõ ha cousa por que a deua dhusar, saluo se quiser fazer de ssy neyçio. E esta opinyõ tynham algũus delles. E outros diserom que arreuatada braueza dAmor ẽ a ujda do homẽ nõ sguarda hidade algũa, porque, em quanto hi ha azeite pera queymar, a llanpada mũỹ de ligeiro se açende de tal fogo, que aadur se apaga, saluo se he algũu homẽ santo que Deus por sua graça spiçial quer preseruar. Assy que estas opinyõoes e outras muytas passarom, ataa que Cupido e sua madre forom âbos auysados sobre a determynaçõ, a que ponto auyam de condesçender.

Em quãto estas cousas passarõ eu jouue quasy morto, en tanto que de todos fuy julgado que daquella uez era per fforça morrer. Mas este deus, çego, como aquel que entom queria partyr comigo da sua graça, poendo as mãaos sobre meu corpo, pareçeome que tyrou fora de mỹ o dardo queymante con que elle em antes passara o meu coraçom. E tanto que esto ouue acabado foysse nõ sey pera onde. $\mathrm{E}$ assy fezerom os outros que o aguardauom. Mas Venus nem o sseu clerigo Genyus nõ sse partirõ de mỹ, mas ficarom anbos jũto comigo. E Uenus, que os coraçõoes [24rb] dos homẽes nas causas damor pode atar e desatar, teendo hũa buçeta nas mãaos, como aquella que auya uoontade de me guardar de morte, tirou fora da buçeta hũu yngoento mais frio que a neue, com o qual hũtou a ferida de meu coraçom e as fontes e conjũturas de meu corpo. E deume hũu spelho en que me bisse e parasse mẽtes ao que em elle acharia. Em o qual lançey os olhos do meu coraçom e by en como a mjnha collor era ia botada e os meus olhos tristes sem lidiçe e as queixadas delgadas e o rrostro enuerrugado. Vy outrossy meus cabellos todos cãaos, e, porque nom by cousa em mỹ en que ouuesse prazer, mjnha uõtade nom quis conssentyr que eu oolhasse mais em el. Entom me nẽbrey do tenpo passado e da hidade en que staua e, ssegũdo o conpassamento de mjnha rrazõ, fiz semelhança de mỹ aos doze meses do ano, que em seu stado senpre stã em desuayro.

\section{[Capítulo XXXVII] En como o estado do homẽ he semelhauel aos doze me- ses do ano.}

[A]quel que quiser parar mentes aos tenpos do ano, começando des março ataa que o mes dagosto seia passado, pode trazer aa sua rrenenbrança a condiçom da poderosa mançebya; ẽ o qual tenpo [24va] o ano dentro en ssy toma allegramento das heruas, flores, folhas, fruytos, pãaes e huuas e bynhadas. E depois que o tenpo he ordena[do] pera gear, neuar, ventar e chouer, o ynuerno nom quer conheçer ao verãao, ataa que uenha outra uez o mes de março. Porque, tanto que uem o jnuerno, a terra de quẽete torna frya e de ssuas folhas uerdes fica desuestida.

E, en penssando sobre materia, acordey do meu sono, feito storuynhadamente, como homẽ contoruado do entendimento. E depois que fuy tornado a 
meu acordo e que Rrazom ouuyo dizer que os tormentos dAmor eram ia afastados, logo se ueo direito pera mỹ e lançou fora do meu coraçom a doudiçe e fantasya de que me eu em antes querellaua; ẽ tal guisa que das ardentes penas que sohia padeçer fiquey tenperado e sãao, como se nũca de tal cousa ouuesse sentido. Venus, oolhando ẽ mỹ, começou de rj̃ e em maneira de jogo pregũtoume que cousa era Amor. E eu, com uergonha, nõ lhe soube dar rreposta, saluo que lhe jurey que tam alongado era do meu penssamento, que nom auya ia delle conheçimento nem sentido. «Filho meu», disse ella, «por agora eu creo que tu dizes uerdade, ca tal sse quer a Fortuna da mjnha rroda. Porem, eu te cõ[24vb]sselho que nũca ia mais te enpaches de cousa que a sseu ofiçio perteeça». "Senhora», disse eu, «uos sabees bem en como ia nõ soo perteençẽte pera serujr uossa corte. E pois tal nom sõo que possa em ella merçer grado e bou lançado fora a modo de rrefugo, peçouos que me nom culpees e me aiaaes de todo en todo por scusado».

«Aallem desto, por fynal conclusõ do que foy feito ataaqui en rrazõ de mjnha confissom, en quãto eu stou em meu entendimento, demãdo a Genyus que me assolua ante que sse daqui parta». O Clerigo, stando ally prestes disse logo: «Filho meu, quãto he das cousas de tua cõfissom, ssey çerto que es perdoado e assolto conpridamente. E por ende a ty seia squeeçido o que me disseste, ca eu da mjnha parte nũca ia mais serej dello nẽbrado». «Meu sancto padre», disse $\mathrm{eu}^{52}$, «a uos grandes merçees.» $\mathrm{E}$ desy puseme en giolhos sobre o prado uerde per ante a deessa Venus, e spidyme della com entençom de me hir meu camjnho. Mas esta onrrada rraynha, como aquella que me queria apropriar a cousa pera que eu era mais apto, lançou darredor de meu collo dazeujche hũas cõtas pretas e rredondas, nas quaes ãdaua scripto «Pour rreposer» com leteras douro, dizendo:

«Joham Goer, [25ra] por quãto tu agora stas sobre a fỹ de tua derradeira sorte, eu por tua folgança tenho ordenado que daquy en diante nõ te tremetas de conplazer nem buscar Amor. Mas mjnha uoontade he todauya que te trabalhes de orar e rrogar por paz, ẽ que faças conprido rrelleixo a Amor, o qual dos uelhos faz pequena conta ao tenpo que os seus delleitos som guastados. Por ende, tu nom tees senom hũu camjnho soo, em o qual conpre que Rrazõ seia tua guya. Porque aquel que nom uee o perigoo ante que uenha, mũy asinha perdera sy medes por mjgua de boo rregimento. Por esto, filho meu, sey senpre auysado e nom te squeeça a sentença desta doctrina que te ora direy: Nom enpaches mais a mjnha corte, mas uay buscar õde uirtude moral tem sua morada, segundo eu ouço dizer que nos liuros de lõgo tenpo tees studado faz mençõ. Ca digote por çerto que sse o camjnho da tua saude quiseres catar ${ }^{53}$, nõ te conpre de fazer segujda sobre feito que nom he pera poer em proua, porque nom concorda cõ rrazom que nehũu homẽ por o querer fazer seia tam desauysado. Porẽ, para mentes a esto que te ora rrazoo e nẽbrete en como, segundo a geeral [25rb] husança da mynha ley, tu e eu somos hordenados de nũca ia mais comunycarnos em feito d'amor.

52 'eu': 'elle' tachado y 'eu' sobrescrito encima.

53 'catar': 'scapar catar','scapar' tachado. 
Ora, pois dicto hey o que te queria dizer por fynal conclusom do teu amor, filho meu, a mỹ conuem dhir. Adyu, que nom posso aqui mais tardar. Pero sauda da mynha parte Chauçer, meu desçipollo e meu poeta, quãdo com el topares, como aquel que por o meu, na froll de sua mançebia, fez toda sua dilligençia pera conpoer e screuer dizeres e cantares de desuayradas maneiras, das quaees toda a terra he chea, por a qual cousa em spiçial sobre todollos outros lhe soo muyto theuda. Porende, dilhe que lhe enuyo dizer que elle em esta sua derradeira hidade, por tal de fazer fym de todas suas obras, trabalhe de fazer seu Testamento dAmor, assi como tu aqui has feita agora tua confissom». «Senhora», disse eu, «a mỹ nenbranra bem de lhe dizer esto que me auees dado por encarrego.»

E, ditas aquellas pallauras, assy aconteçeo que ella, çarrãdosse em hũu çeeo cheo destrelas, subitamente desapareçeo da mjnha bista e se foy dereito pera o Parayso. E eu, de meu cabo, da mata onde jazia aderençey meu camjnho e fuyme pera mjnha casa, onde [25va] com as mynhas contas nas mãaos, em quãto eu biuer, com boa entençõ entendo de rrogar a Deus por todos aquelles que, segundo o effeyto da mjnha cõfyssom, deseiam o uerdadeiro Amor.

[Capitulo XXXVIII] Aqui screue os onrrados e uirtuosos costumes dElRrey Rycharte, seu senhor, rogando a Deus müỹ deuotamente que em onrra quysesse senpre guardar seu stado e, depois da sua morte, a a sua alma desse folgança conprida em seu Parayso pera todo senpre.

[A]quel que de sua eternal prouydençia o çeeo e este mũdo todo em seys dias formou e aprouue despyrar na alma do homẽ aquella ỹtelligẽçia rrazoauel per que el sobre todallas criaturas terreas, quãto aa alma, fosse ynmortal e semelhante a esse medes; a este Senhor, que de todallas cousas he dador e em cujas mãaos stam as fortunas dos rreys, por guãaçar graça, em giolhos nuus omjldosamente rrogo e peço que El senpre queira mãteer e guyar a honrra do meu boo senhor, per nome chamado Rycharte o Ssegũdo. Em o qual justiça cõ piedade e largueza cõ caridade ataaqui continoadamente forom achadas. Ca per el os rreys podẽ [25vb] tomar exenplo de seerem bem acostumados, spiçialmente na uirtude da piedade, como aquel que por erros que nos sobdictos da sua terra achasse nũca sobrello per uya de crueleza quis buscar byngança. $\mathrm{E}$, posto que assy fosse que os aqueeçimentos mũdanaaes de ynfortunas ẽ seu tenpo obrassẽ grandes desaueenças, pero elle en ssy nõ foy porem jnffurtunado. Porque aquel alto Deus, gujador da fortuna, de justiça sua assoonbrou a el de tal guisa e o guardou, que o seu stado sẽ magoa em seu graao senpre ficou saluo. Semelhante ao sol, o qual, ajnda que com nuuẽes aas uezes seia assoonbrado, dentro en ssy nom leixa de sseer senpre luzente e fermoso, nõ auendo culpa da scuridõoe que as tenpestades fazẽ sobre a terra. Assy que este prinçipe honrrado de que eu screuo sta bẽ claro cõ todo o mũdo, e por saluaçõ de sseu poboo trabalha quãto pode por contynoar concordya e paz, nom tam soomente aqui na terra, mas em outras partes de fora. Por a qual cousa nos todos somos obrigados, scilicet os seus sojeitos, obedeçer e serujr a el, que de sua alta sofrença por bem de sseu poboo [26ra] tem apagados grandes debatos per muytas partes, de que a cronyca pera senpre ficara em memoria. Porque sabudo he a todollos homẽes que aquel que em esta guisa deseia dauer paz toma o camjnho que Christo per ssy medes scolheo. E quem as peegadas de Christo segue, notorio he 
que el squiua os viçios e he en ssy uirtuoso, por cuja uirtude conuem que seia mereçedor dauer a graça de Deus. Ao qual, eu, que stou na sua sojeyçom e deffendimento, rrogo da mynha parte, e nom çessarey de rrogar em quãto byuer, que el a aquella fym queira senpre asessegar seu rregno. E, nom enbargando que eu seia tal q[ue] me ora nom posso manear por doença e por uelhiçe que padeço, nẽ esso meesmo por meriçimento de boo serujço que eu ataaqui fezesse nom possa guãaçar graça deste rey meu senhor, pero a mjnha pobre synpreza senpre deseia de fazer prazer ao amor da mjnha sojeyçom.

Por a qual cousa eu offereço aa sua alta nobreza este pobre lyuro scripto de meu synprez trabalho, aos tenpos que pera ello a mynha jnfirmydade me daua uagar. E, assi como eu dise, [26rb] quãdo este lyuro começey descreuer, parte das cousas del podem seer tomadas por joguetar e rrỹr e parte por siso, aos que de siso quiserem husar. Assy que a hũa por bem e a outra por prazer e sollaz eu o tenho ia acabado, per aquel senhor que ante disse, ao qual eu peço que me nom culpe, aỹda que no rrazoar delle nom teuese a forma da elloquençia, pero que aquella falla nom conprende o meu pequeno saber. Mas eu hej feita toda mjnha dilligençia pera em pallauras chãas e rrobustas mostrar estas cousas todas que ditas hey. E agora, pois assy he que eu soo uelho e fraco, e tenho conposto este liuro aa honrra de meu rrey, spiçialmente em Amor, a mjnha sabedoria me consselha por meu mjlhor que daqui en diante tome folgança, quãto he pera screuer mais dos feitos dAmor. Porque aquel que a ssua võtade tem ẽ Amor por seu parçeyro, a este perteeçe de cantar e dançar e fazer as outras obseruançias que a Amor som deuudas, em fazẽdo seus cantares e dizeres segundo os dilleytos dos seus jogos por [26va] tem rrecadado o que queria. Mas onde o homẽ demanda amor e nõ o pode auer, o sseu feito sta em outro termo. O ssabedor diz por enxenplo «Quãdo o iogo he mjlhor entom he mjlhor de o leixar»; por ẽde, eu fynalmente me speço ora descreuer mais dAmor ou da sua mortal saude, ao qual nehũu phisico pode dar rremedio. Porque a natureza del he en ssy tam desuayrada, que do mũỹ muyto e do mũỹ pouco senpre tem algũa contrariedade, en tanto que nehũu homẽ sem algũu fallimento pode ẽ el conpridamente auer seu deseio.

Mas aquel Amor que no coraçom de homẽ sta fyrmado sobre caridade nõ he pera rreprender, mas he pera mereçer guallardõ do bem en todo llogar, por quãto tem en ssy contrapeso per que a conçiençia possa seer carregada. E por ende tal Amor como este, que he boo, todo homẽ em spiçiall se deue de chegar a el e arredarsse de todollos outros delleytos que, segundo rrazõ, deuyam sseer despreçados. A qual cousa nos outorgue o alto Deus com o rremanente da sua graça, en tal guisa que em Parayso, onde amor e paz [26vb] stam em asessego, o nosso prazer pera senpre possa durar.

$* * *$

\section{Liber est scriptus}

Laudetur senper Christus.

Este lyuro, per graça do mũỹ alto senhor Deus, screueo, per mandado de dom Fernando de Castro o Moço, na çidade de Çepta, em xxxxta dias no ano de 1430, Joham Barroso. 